
The lniuraty af Chiragn

TOUNDED BY JOHN D, ROCKEEELLEB

\title{
THE COURT AND THE LONDON THEATRES DURING THE REIGN OF ELIZABETH
}

\author{
a Dissertation \\ SUBMITTED TO THE FACULTY OF THE GRADUATE SOHOOL OF ARTS AND \\ LITERATURE IN CANDIDACY FOR THE DEGREE OF \\ DOCTOR OF PHILOSOPHY \\ (DEPARTMENT OF INGLIBH)
}

BY

THORNTON SHIRLEY GRAVES

MENASHA, WIS.

THE COLLEGIATE PRESS

GEORGE BANTA POBLISHING CO.

1018 


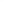

.

.

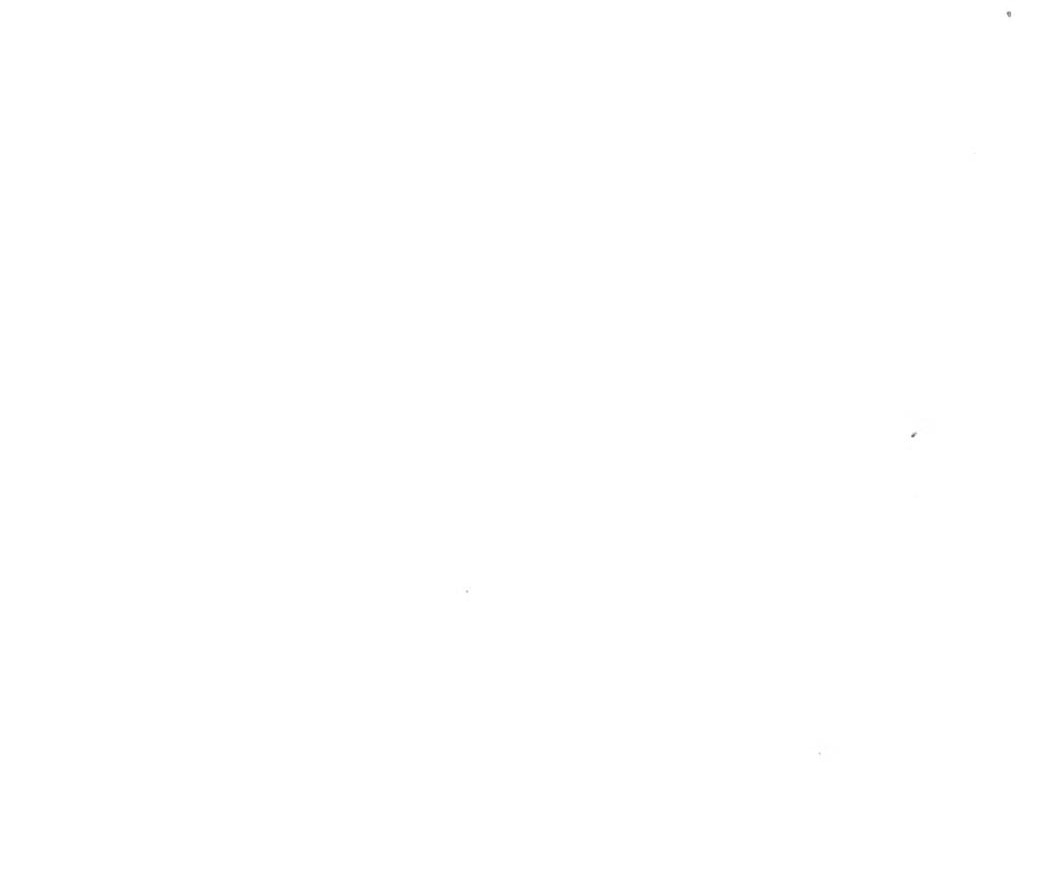

, 


\section{THE COURT AND THE LONDON THEATRES DURING THE REIGN OF ELIZABETH}

ERRATA

Page 25, line 24. For Milton read Melton.

Page 32, line 2. For "early in the nineteenth century" read "late in the eighteenth century".

Page 34, line 28. For Howe read Howes.

Page 36, line 5. For Howe's read Howes'.

Page 39, line 22. For "four" read "all".

Page 43, lines 4 and 17. For Howe read Howes.

Page 67, line 7. For George-a Greene read George-a-Greene.

Page 69, line 19. For Cross read Crosse.

Page 85, line 18. For Burgley read Burghley. 



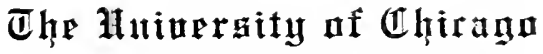

FOUNDED BY JOHN D. ROCKEFELLER

\section{THE COURT AND THE LONDON THEATRES DURING THE REIGN OF ELIZABETH}

\section{A DISSERTATION}

SUBMITTED TO THE FACULTY OF THE GRADUATE SCHOOL OF ARTS AND LITERATURE IN CANDIDACY FOR THE DEGREE OF DOCTOR OF PHILOSOPHY

(DEPARTMENT OF ENGLISH)

BY

THORNTON SHIRLEY GRAVES

MENASHA, WIS.

THE COLLEGIATE PRESS

GEORGE BANTA PUBLISHING CO. 


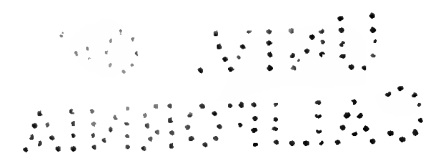




\section{PREFACE}

Most of the conclusions in the following monograph were reached in the fall of 1910 and presented a little later before the seminar in Elizabethan Literature conducted by Professor F. I. Carpenter. A short time afterwards Neuendorff's Die englische Volksbühne im $Z$ eitalter Shakespeares became accessible, thus necessitating the rewriting of the first part of my study. The latter part remains substantially as it was originally written. Since the dissertation was accepted by the Department of English at the University of Chicago, Professor Feuillerat has printed for the German Shakespeare Society the documents proving the existence of an earlier Blackfriars, Professor Wallace has brought out his Evolution of the English Drama, and Mr. W. J. Lawrence has published his two volumes of essays, The Elizabethan Playhouse and Other Studies. Very recently Mrs. C. C. Stopes's James Burbage has appeared. I regret that $I$ have not been able to make use of the recent works of these scholars; yet I do not see that the theory as presented in the following pages is seriously affected by newly discovered facts.

To the earlier published works of Professor Feuillerat and Mr. W. J. Lawrence, my indebtedness is large, as the foot-notes below reveal. I wish, too, to acknowledge my indebtedness to my friend G. F. Reynolds, not only for the help which his articles have afforded me, but also for suggestions privately made. It is a pleasure to express here my thanks to Professors C. A. Baskervill, A. H. Tolman, and R. M. Lovett, who kindly read my dissertation when it was in manuscript. To Professor Carpenter I am obliged for suggesting to me the present study and advising that I pursue it at a time when I would have turned to something else. And finally, to Professor J. M. Manly I am especially indebted for his criticism and encouragement, and for the privilege of examining, before they were made accessible in Murray's English Dramatic Companies, a large body of the extant records of theatrical performances in the provinces.

Durham, N. C.

November 29, 1913. 


$$
\text { - }
$$




\section{CONTENTS}

PAGE

INTRODUCTION

The Structural Elements of the Elizabethan Stage . . 4

The InN-Yards and the Early Theatres . . . . . 32

The Stage at Court and the Early Theatres . • . $\quad . \quad 50$

Court Influence in General . . . . . . . . . 68

Appendix. The "Canopy Stage" . . . . . . . 88

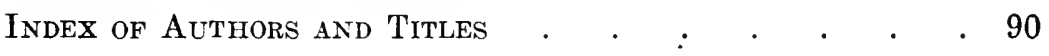




\section{-}

$\checkmark$ 


\section{INTRODUCTION}

Years ago George Steevens in his endeavor to prove the use of scenes in Elizabethan theatres ended his argument with the following words :

"To conclude, the richest and most expensive scenes had been introduced to dress up those spurious children of the Muse called Masques: nor have we sufficient reason for believing that Tragedy, her legitimate offspring, continued to be exposed in rags, while appendages more suitable to her dignity were known to be within the reach of our ancient Managers. Shakspeare, Burbage, and Condell must have had frequent opportunities of being acquainted with the mode in which both Masques, Tragedies, and Comedies were represented in the inns of court, the halls of noblemen, and in the palace itself." 1

This, it seems to me, is a thoroughly sane point of view from which to approach the Elizabethan stage. Owing, however, to Steevens's unsuccessful encounter with Malone on the subject of modern scenes, and to certain unduly emphasized statements by such personages as Ben Jonson and Sir Philip Sidney, scholarship has until recently insisted on considering the Elizabethan regular and court stages as things apart and unrelated, the one arising from an humble inn-yard original and contenting itself with pleasing an uncultivated inn-yard taste, the other springing from a more aristocratic prototype and holding itself rigidly aloof from its less pretentious contemporary. ${ }^{2}$

And even now when the blanket and bare platform which once satisfied students as a background for Shakspere's poetry have been generally discarded, there is still a tendency on the part of some to exclude court influence altogether, or to admit it only late in the reign of James $\mathrm{I}$, implying that the regular theatres during the Elizabethan era proper progressed but little in equipment and efficiency of presentation beyond the pageant-wagons which two centuries earlier had rolled about the streets of England.

But an explanation of the equipment and practices of the

1 Quoted in Malone-Boswell Shakespeare of 1821, III, 106, note.

${ }^{2}$ For the probability of court influence in staging, see Reynolds, Mod. Phil. (1905), p. 73; Schelling, Eliz. Drama, I, 107; Neuendorff, Volksbühne, passim; and especially Feuillerat, Le Bureau des Menus Plaisirs, pp. 81-86. 
Shaksperian Theatre is not to be songht for in mystery plays. Nor are they to be accounted for by accepting satire at its face value while ignoring or explaining away statements of a contrary nature; or by maintaining that the early London playhouse was exclusively popular in origin and method, a folk institution, as it were, where noise and buffoonery, swordplay and oratory, were the only essentials for a successful two hours' traffic of the stage.

Such a view is not only eminently unfair to the professional actors and the Elizabethan audiences, but is out of keeping with the whole spirit of the age. It fails to take into proper consideration the prominence in theatrical matters of a court which from the time of Henry VIII had been accustomed to entertainments as elaborate and impressive as sixteenth century England could devise; and it neglects to recognize the various opportunities for court influence upon the London stages long before the reign of James, the numerous incentives for such an influence, the open-mindedness of Elizabethans, and the business sense possessed by such managers as Burbage and Henslowe.

The object of this study, therefore, is to approach the London theatres from an entirely different point of view, the court, and to point out the probability of influence prior to 1603 . Features of similarity and possible court influence are, I believe, to be found in the general stage structure of the earlier theatres, in certain principles and practices of staging, in various theatrical devices employed for realistic and spectacular effects, and in the general nature of the properties and costumes employed in public performances during the reign of Elizabeth.

Such a study, like all studies of the Elizabethan stage, is beset with difficulties and uncertainties. In most respects conclusive results are as yet impossible; theories are incapable of demonstration to the satisfaction of all. Students of the stage are at most dealing with probabilities. Owing, however, to the labors especially of Feuillerat and Reyher, we are able to stand on comparatively firm ground in our discussion of the methods employed at court performances; and at court, it must always be remembered, Shakspere and his fellows acted dramas which were also presented at the public theatres. It is hoped, then, that a study from this point of view, unsatisfactory as it necessarily is, may contribute toward the 
solution of certain problems which at present confront the students of the Elizabethan theatre.

In undertaking such a study, it has seemed advisable to divide the discussion into four parts. The first is devoted to a discussion of the structural elements of the Elizabethan theatre with especial reference to the recent theory advanced by Neuendorff in so far as it conflicts with the theory of the present writer; the second concerns itself with the inn-yard and its relationship to the first London playhouses; the third attempts to establish the probability of court influence in general stage structure at the early public theatres; and the fourth deals in a more general way with the indications of court influence in the methods of presenting dramas at the regular playhouses during the reign of Elizabeth. 


\section{THE STRUCTURAL ELEMENTS OF THE ELIZABETHAN STAGE}

Notwithstanding the great diversity of opinion regarding certain features and practices of the Elizabethan playhouse, there is now general agreement as to the existence of a balcony or upper stage in all the theatres of Shakspere's time. It is generally believed, too, that beneath this upper stage was suspended in most of the theatres of the period a curtain flanked on each side by a door opening upon the outer stage. Behind these doors, it is thought, were the property and dressing rooms, the whole back portion of the stage being often called the "tyring-house".

This, I helieve, was in its essential elements the regular form of the Elizabethan stage from the time of its construction in 1576. Perhaps when managers and actors realized more and more the possibilities of the "place behind the stage" or "alcove" or the "canopy"," they enlarged it; perhaps the oblique doors are a later touch; but that the general plan of two side doors with a middle entrance through rear stage and curtains was in operation from the beginning, and that it was suggested by the Court stage or stages seems highly probable.

Of course this form of stage cannot be actually proved for the Theatre and Curtain. It has hardly been proved at the Rose, although we know with respect to this particular playhouse that it liad a balcony and a curtain, three entrances, and behind the stage a place which was presumably larger than the space concealed by a single door. The existence of a similar type of stage can, I believe, be established as probable at the two earlier theatres. To remove certain possible objections to such an idea is the chief object of the first part of this study. The probable court origin of such a type of stage will receive treatment in a later part.

As any such theory is in certain respects radically opposed to that offered by Nenendorff in his recent book Die englische Volksbühne, it is fitting at this point to give a criticism of those features of his study which conflict with the probability of such a theory. Basing his conclusions on what he calls direct and indirect sources

\footnotetext{
"For a distinction between the "alcove" and "canopy" see below and Appendix I.
} 
of evidence, he finds three main types of stage in use during the period 1576-1642. The first is a stage without a curtain and with an undivided lower stage. This, he thinks, is the most primitive type, the first experiment in stage building. It is represented in the Red Bull and perhaps in the Roxana ${ }^{2}$ pictures. The second type is a lower stage lying entirely before the balcony, divided into two parts by pillars, and approached by two (or three) doors at the rear. The Swan picture is representative here. This, I take it, is the second experiment. The third type, or fully developed stage, is that shown in the Messalina picture, the "canopy stage", as I shall term it; that is, a structure where the rear stage consists of a recess ( $\mathrm{A}$ in the figure below) separated from the front stage (B) by a curtain $\left(\mathrm{aa}^{\prime}\right)$ and situated beneath a balcony, or upper stage, projected a few feet beyond the line of the side entrances ( $x$ and $y$ ) and supported at the front by two pillars (a and $a^{\prime}$ ), which pillars are not to be confused with the larger ones ( $b$ and $b^{\prime}$ ) supporting the shadow over the front stage.

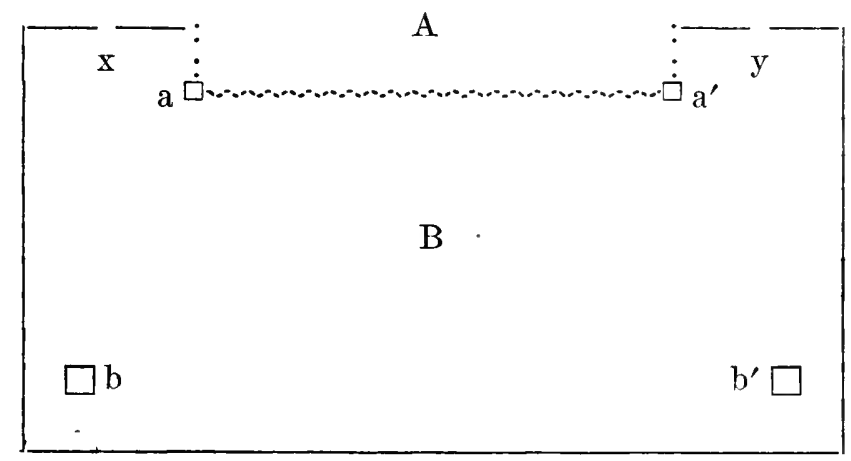

Along with these various experiments in stage building he traces a more or less regular development in the method of staging. The steps in this development should perhaps be given in his own words: "Blicken wir zunächst zurück: wir hatten gesehen, dass ein einheitliches Bild von der englischen Bühne nicht zu erhalten war. Zur Shakespeare-Zeit stehen wir noch in den Anfängen des Theaterwesens, denn greifbare Versuche konnten erst mit dem Bau

${ }^{2} \mathrm{He}$ apparently considers the Curtain and Theatre to be curtainless (p. 32). Whether he would regard either as being so primitive as the stage shown in the Red Bull picture, I am unable to say. 
fester Theater gemacht werden. Und so wurde zweifellos experimentiert - eine Reihe von Bühnenformen liess sich nachweisen, Bühnenformen, die eine Entwicklung darstellen.

"Hand in Hand mit dem Fortschritt im Bau der Bühnen ging eine Entwicklung in der Behandlung des Ortes. Diese Entwicklung vollzog sich in drei Stufen, die zwar durchaus nicht streng zu scheiden sind, aber in dem Sinn Geltung haben, dass die erste die am frühesten verschwindende ist (abgesehen von wenigen Resten), die zweite sich länger neben der dritten hält, die dritte aber die herrschende wird. Die Einteilung in Stufen ist also nicht nach dem Auftreten, sondern nach dem Verschwinden, oder doch wenigstens nach dem Zurückgehen, vorgenommen.

"Die erste Stufe ist darnacl die gleichzeitige Darstellung mehrerer Orte auf der Bühne. Die zweite ist die Fiktion mehrerer Orte nacheinander innerhalb derselben Szene. Die dritte Stufe ist erst die einer realen Ortsbehandlung: entweder Verlegung verschiedener Örtlichkeiten auf verschiedene Bühnenfelder oder aber Beschränkung einer Szenenhandlung auf einen Ort"' (pp. 202-3).

Now let us pause to determine the significance of Neuendorff's theory in its relationship to the theory outlined above. Neuendorff is doubtless right in supposing that there was a progress in the method of staging. My discussion of the nature and cause of this development will be found in a later section. His fundamental error, it seems to me, lies in his contention that this development went hand in hand with various experiments in stage construction. Indispensable for any such theory is, not only the construction of numerous radically different types of stage between the years 1576 and 1642, but also the widespread existence of a very primitive method of staging on an equally primitive form of stage. To secure these necessary primitive conditions, he sometimes resorts to late plays, notably Suckling's Aglaura, for evidence; and he uses a very late picture, that of the Red Bull, to illustrate his most primitive type of stage, in spite of the fact that this picture is of little or no value in such a discussion. ${ }^{3}$ He has great faith in the accuracy of the DeWitt drawing of the Swan, and hence uses it as his chief evidence in arguing for the prevalence of the vorhang-

- Albright, Shakesperian Stage, pp. 40-43; Lawrence, Eng. Studien, XXXIX, p. 404; Reynolds, Some Principles, I, pp. 12-13. 
lose Bühne. He admits curtains at the Rose and thinks that it belongs to the Messalina or fully developed type of stage. He admits this, let me repeat, yet he does not offer a satisfactory reason why the Swan, as represented in the drawing, has neither curtains nor any place for them in spite of their earlier existence at the Rose, ${ }^{4}$ and the significance of such conveniences in staging; thus advancing what seems to me, I must confess, the inconceivable idea that even after the curtained stage, the fully developed or "canopy stage", was in existence, the vorhanglose Bühne continued to be constructed and used. He throws doubt on certain evidence pointing to curtains at the Blackfriars; he is skeptical regarding the existence of stage curtains at the Globe and Fortune; and on page 29 he writes that these two theatres, together with the Swan and Hope, apparently belong to the same general type of stage. $\mathrm{He}$ says further (p. 43): "Schon jetzt aber erkennen wir, dass die vorhanglose Bühne - drei ron den überlieferten Bildern stellen eine solche dar-eine viel grössere Verbreitung in der Shakespeare$Z$ eit hatte, als wir im allgemeinen annehmen'. On this widespread curtainless stage, he asserts, the functions and effects of curtains were secured by the use of canopies, curtained beds, thrones and stage doors.

Neuendorff's theory, then; is built up on the assumption that the vorhanglose Bühne was a common institution in sixteenth century England. And it is just here that his theory conflicts vitally with the one set forth in the present study; for if it can be established that the rorhanglose Bühne, a more primitive form of stage than that at the Rose, was a widespread type in the days of Shakspere, then there are good a priori reasons for believing that the two earliest playhouses-the Theatre and the Curtain-conformed to this type rather than to that of the Rose. The real question at issue therefore is, Was the vorhanglose Bühne with its various modifications a common form of stage during the Elizabethan period?

Now personally I do not believe that there was ever such a thing as a corhanglose Bühne among the regular London theatres from 1576 to 1642 . That many plays could be, and were, staged without

4 The early Blackfriars, which was perhaps the same type of stage as that at the Rose, does not enter into the discussion for the reason that the documents proving its existence were accessible too late to be of service in the preparation of my dissertation. 
the use of a curtain is undoubtedly true, but this has little or nothing to do with the point under discussion. That rear stage scenes are comparatively rare is also quite true-it is only natural that they should be so-and that doors were sometimes used to represent shops or even studies may be admitted without affecting the question at issue.

In favor of the general use of stage curtains may be urged the theatrical instinct for such conveniences, the common sense of Elizabethan theatrical people, and the existence of curtains in theatrical entertainments from the earliest times. They may not have been common on the pageant wagons of the cyclic mystery plays, but it is certain that they were used in stationary performances in England ${ }^{5}$ as well as in France. ${ }^{6}$

At court entertainments curtains were used at least as early as the time of Henry VIII. In 1511, for instance, a curtain suddenly falling at one end of the hall revealed a gorgeous pageant. ${ }^{7}$ In 1518, "immediately after a curtain had been lowered, a handsome triumphal car appeared, with a castle and a rock, all green within and gilded. Within the rock was a cave all gilded, the gates being of wood with silk curtains, like a recess; and within the cave were nine very handsome damsels with wax candles in their hands, all dressed alike, looking through the veil, like radiant goddesses"'. At Greenwich, in 1527 , there fell at the extremity of the hall "a painted canvas [curtain], from an aperture in which was seen a most verdant cave". 9 In the same year at York Place a curtain fell, revealing Venus surrounded by six maidens seated on a sort of scaffold. ${ }^{10}$ Gibson's accounts for this year contain "ironwork to hang the curtains with, 2s.", "4 doz. curtain rings, 4 d.", " a whole piece of cord to draw the curtains, 14d." "11 Not very clear is the direction in Godly Queen Hester (1. 140), which Greg and Bang think was acted at Court between 1525 and 1529: "Here the Kynge

- Coventry Plays, Publ. Shakespeare Soc., II, pp. 261, 303.

${ }^{\circ}$ Creizenach, I, 166; Cohen, La Mise en Scène dans le Théatre Religieux Français, pp. 144-146.

7 Hall, Chronicle, p. 518.

${ }^{8}$ Cal. State Papers, Venetian, 1509-1519, p. 466.

Ibid., 1527-33, p. 60 .

${ }^{10}$ Ibid., p. 2 ; cf. Hall, p. 723.

11 Brewer, Letters and Papers of Henry VIII, IV, pp. 1391, 1604. 
entry the travers \& Aman goeth out'. Even more vague is the rope used for the "travas" in the hall at Greenwich in 1511."2

Curtains at court during the reign of Elizabeth were regular features at performances. The only question is whether front curtains were employed. ${ }^{13}$ Universities and the Inns of Court recognized the value of curtains. In Legge's Ricardus Tertius, acted at Cambridge in 1579 , occurs the direction: "a curtaine being drawne, let the queene appeare in ye sanctuary, her 5 daughters and maydes about her, sittinge on packs, fardells, chests, cofers. The queene sitting on ye ground with fardells about her''. ${ }^{14}$ At Gray's Inn on Jan. 3, 1594, "at the side of the hall, behind a curtain, was erected an altar to the goddess of amity', etc. At the conclusion

12 Brewer, Letters and Papers, II, p. 1497.

${ }^{13}$ Corbin (Atlantic Wonthly, 1906, p. 380) says that front curtains were undoubtedly used at Court, citing as his evidence the entry in the Revels Accounts for 1573.4, "John Rosse, for poles and shyvers for draift of curtins before revel [mistake for 'senat'] house, 25s.", and the entry for 1581 to the effect that "Pompey's Senate House' had eight ells of double sarcenet for curtains." These entries do not prove front curtains. Likewise Professor Baker (Development of Sh., pp. 84-5) asserts that "front curtains" can be "perfectly established for performance at Court". That front curtains were used at court plays is undoubtedly true, but the entries on pages $85,86,90$ of Cunningham's Accounts of the Revels, cited by Professor Baker, do not necessarily point to them. More convincing is the entry to the effect that "a pastorall of phillyda \& Choryn" employed "one greate curterne" together with "one mountarne and one great cloth of canvas" (Feuillerat, Doc., p. 365). Front curtains at court, however, were not employed to conceal the shifting of properties, as Professor Baker evidently believes, but were opened at the beginning of the play and left open until the end when they were again closed, a practice corresponding to the operation of the curtains in the Stuart masques (Lawrence, Eng. Illustrated Ifagazine, Vol. 30, p. 181), or the raising of the curtain at the beginning of a play on the Roman stage and lowering it at the conclusion. Their purpose was to conceal the stage until the play was begun, when the elaborate setting was suddenly revealed to the audience, just as the curtain which suddenly fell in 1511 revealed with an element of surprise the splendid pageant which moved into the hall. The sudden revelation of elaborate scenery by the drawing of a curtain was common in the later masques (Reyher, Les Masques Anglais, pp. 356-7). A similar derice at an early date was the casting aside by masquers of their long loose gowns, thus startling the spectators with the splendor of the costumes beneath them. (Ibid., pp. 411-412).

The curtain which opened at the beginning of the entertainment at Gray's Inn on Jan. 3, 1594, and which at the conclusion was "drawn as it was at first", is an illustration of this practice. The words of Julio at the end of Tancred and Gismunda, "Now draw the curtains for our scene is done", probably refer to the same practice; while the direction at the beginning of Marlowe and Nash's Queen Dido, "Here the curtaines draw, there is discovered Jupiter dandling Ganimed upon his knee, and Mercury lying asleepe", no doubt refers to the drawing of the large front curtain, thus rerealing the entire setting of the plas-a "city", the palace of Dido, and a wood. It is possible, too, that the well-known direction at the beginning of David and Bethsabe, where the prologue draws a curtain and discovers Bethsabe bathing and Darid sitting above watching her, is a vestige of a court performance of this particular play. Possibly the same is also true of The Sun's Darling and The Whore of Babylon.

1s Hazlitt, Shakespeare's Library, II, pt. ii, p. 145. 
of the performance, "with sweet and pleasant melody, the curtain was drawn as it was at first". 15

Curtains were used on the pageants drawn into the halls of the time. One case in the reign of Henry VIII has already been cited. And the "Rocke, or hill ffor the ix musses to Singe uppone with a vayne of Sarsnett Drawen upp and downe before them", mentioned in 1564 in connection with a "maske of hunters" and "a play maid by Sir Percyval hartes Sones", ${ }^{16}$ was perhaps a movable structure. Whether curtains were used in the outdoor city pageants of the time, I do not know, but it is certain that at no late time they were used for the purposes of surprise and symbolism. When James I entered London, one of the devices was got up by the Dutch. Above the "Heart of the Trophee" was a "spacious square roome, left open, silke curtaines drawne before it: which upon the approch of his Majestie being put by, Seventeen yong Damsels, all of them sumptuously adorned after their countrey fashion, sate as it were in so many chaires of state". ${ }^{17}$ A curtain painted like a cloud was similarly used in Jonson's device at Fenchurch on the same occasion. ${ }^{18}$

Curtains, whatever may have been their function, are not unheard of in public performances as early as cir. 1530. This is brought out in the Walton-Rastell lawsuit, ${ }^{19}$ where among the playing parcels confessed by Walton are "Two curtains, of green and yellow sarcenet". And curtains of green and yellow sarcenet, it may be noted, remind one of the striped curtain which, according to George Steevens, adorned the sign of the Curtain theatre. ${ }^{20}$

Such references as these, to be sure, do not prove an "alcove" at the Theatre or Curtain, but they do argue, it seems to me, against the supposition that experienced theatrical people when they undertook to construct permanent theatres would deliberately erect stages on which such theatrical commonplaces and conveniences were impossible or practically useless, platforms on which the effects ordinarily secured by curtains were more or less acceptably secured by the use of stage doors, canopies, curtained thrones and

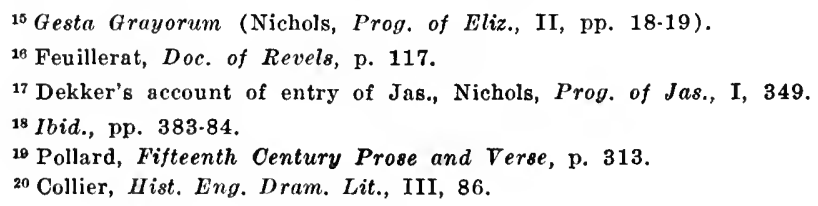


beds. That such makeshifts were resorted to on improvised stages or in provincial tours I am willing to admit, but that they were ever used in the regular London theatres because a stage curtain was lacking, I must as yet refuse to believe. Neuendorff himself was acquainted with the early use of curtains in English theatricals at court and elsewhere, but he does not give such a fact the importance that it deserves. The proof of a curtain at every London theatre for every year of its existence is probably impossible, but such is entirely unnecessary to establish beyond all reasonable doubt the general employment of a theatrical commonplace.

That canopies above beds, canopies above thrones, canopies to be borne above actors were all used in the London theatres is certainly true, but they were not used as makeshifts for stage curtains.

As a result of his faith in the DeWitt sketch, Neuendorff goes to unnecessary trouble in explaining how Elizabethans overcame the difficulties necessitated by a vorhanglose Bühne. The stage direction in Eastward Hoe, I, 1, "At the middle door enter Golding, discovering a goldsmith's shop and walking short turns before it", certainly seems to mean, as Reynolds pointed out, ${ }^{21}$ that Golding comes in at the door at the back of the rear stage and draws the stage curtain. Neuendorff, ${ }^{22}$ however, asserts that the shop could be discovered by opening a stage door. Of course this is true, provided the doors on the Elizabethan stage were very large and swung out upon the stage instead of swinging back into the tiringhouse, and thus interfering with properties on the rear stage, but why suppose any such process, when the play was presented at Blackfriars where the existence of curtains can be abundantly shown?

Again, of the direction in Henry VIII, II, 2, "Exit Lord Chamberlain; and the King draws the curtain and sits reading pensively", Neuendorff ${ }^{23}$ says : "Wie können wir sonst erklären, dass der König selbst den Vorhang zieht, als durch die einfache Annahme, er sitzt auf dem state, zunächst von dem geschlossenen Vorhang dieses Thronsitzes verborgen, wie das in anderen Fällen sicher

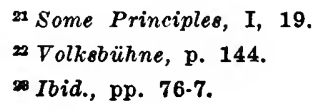


belegt ist'" There is no difficulty here. The direction may well mean that the king drew the curtains [before the alcove] and then sat reading pensively. Or he conld while sitting have drawn the stage curtains practically as easily as the curtain before a throne. The operation is no more complex than are others called for in stage directions. Bobadilla, for example, in Every Man in his Humor (1. 420), "discovers himself on a bench"; and Laverdure in What You Will, II, i, "draws the curtains, sitting on his bed, apparalling himself; his trunke of apparaile standing by him".

While canopies were used, still there is a distinction to be made between a canopy and the canopy of Percy's Faery Pastorall and Marston's Sophinisba. What could be a more appropriate term for the rear stage than "Canopie"? The author of the stage direction preceding Greene's Alphonsus, IV, i, was content to call it the "place behind the stage". Not so with Percy; hence he asserts that over this place behind the stage, the "Canopie", was to be written "Faery Chappell". The fact that he was thinking of a permanent part of the stage and not an ordinary canopy is revealed by considering the word "Canopie" in connection with what precedes: "Highest, aloft, and on the Top of the Musick Tree the Title The Faery Pastorall, Beneath him pind on Post of the Tree The Scene Eluida Forrest. Lowest of all ouer the Canopie NAחAITBO $\triangle A I O N$ or Faery Chappell". The "Musick Tree" and "Post of the Tree", then, were directly above the "Canopie".

There is only one circumstance which in any way implies that a separate structure was employed for the chapel. On page 149 occurs the direction: "Mercury entring by the Midde doore wafted them back by the doore they came in". On page 165 we find the direction: "They enterd at severall doores Learchus at the Midde doore"'.

Says Neuendorff in his endeavor to prove a curtainless stage (p. 75) : "Dass hier nun sicherlich nicht mit der Hinterbühne zu rechnen ist, zeigt III, 5 und IV, 8, in denen Personen durch die Midde doore auftreten. Diese Tür hätte auf einer Bühne mit Vorhang nur zu der Hinterbühne führen können-wo wäre sonst Platz für sie? -, wer also durch die Mitteltür hereintrat, wäre von der Hinterbühne gekommen, d. h. aus der Kapelle. So kann der als Faery Chappel festgelegte Raum nicht auf der Hinterbühne, deren 
Existenz in diesem Falle damit überhaupt verneint werden muss, gelegen haben".

I fail to see the force of any such argument. In the first place, there is no reason why the characters should not have entered through the chapel. In the second place, the mention of a "midde doore" instead of midst, especially by so loose a thinker as the gentleman who wrote at Wolves Hill as his Parnassus, does not disprove a curtain before the rear stage. Plays, for example, published at approximately the same date and written for the same theatre call for a middle door and a curtain. ${ }^{24}$ In the third place, there is some evidence that this very drama calls for a curtain before the "Canopie", or rear stage, in which characters and a banquet are shut later in the play. The scene is a forest. Yet arras are referred to on page 179 where we find the direction: "He tooke from behind the Arras a Peck of goodly Acornes pilld". "Arras" used in the sense of curtains is frequent; and it is rather difficult to see why arras should be referred to in a play calling for three doors and a forest setting, unless the author had in mind the regular curtain (arras) before the rear stage.

This being true, probably the arras from behind which the goodly acorns were taken were closed when Mercury and Learchus entered by the rear door, and as a result they were not conceived as entering from the chapel. Or perhaps the arras were open; hence the author wrote that the characters entered by the "midde doore" instead of "midst". Or it is possible that Elizabethans, like the dramatists of the Restoration, occasionally referred to the opening of the rear stage itself as a door, ${ }^{25}$ although it was larger

${ }^{24}$ Percy's play is itself an illustration. It was written in 1603 for Paul's; yet Antonio's Revenge, V, 2, and Blurt, Master Constable, II, 2, both published in 1602 as sundry times acted by the Children of Paul's, demand a stage curtain. Eastward Hoo, cited above, calls for thre日 doors at the Blackfriars where a stage curtain was certainly omployed. The prologue to the Four Prentices of London (pub. 1615 as acted at the Red Bull) bas the direction, "Enter three in blacke clokes, at three doores"; yet Dekker's If This Be Not a Good Play (pub. 1612 as acted at the same house) calls for a rear stage and curtains. The Brazen Age (pub. 1613, and no doubt acted at the Red Bull) demands a stage curtain, etc.

${ }^{25}$ It is certainly possible that the rear stage in some theatres could bo shut in by large folding doors as well as by curtains (cf. Reynolds, MIod. Phil., IX, p. 58). It should be noted in this connection that Neuendorff is inclined to locate various scenes in a fourth stage, the space behind a door. Any space beneath the upper stage which was large enough to stage a banquet, game at chess, or person lying on a bed, etc., so that the scenes could be observed by the entire audience practically amounts to an "alcove". 
than the side doors. Was Thomas Holyoke, for example, thinking of the Roman theatre when he defined scena in his Latin dictionary (1677) as "the middle door of the stage"? As we shall see later, scene was apparently used at times before 1660 to denote the rear stage itself. Cases in Restoration dramas where door is used to refer to the scene or curtain are rather frequent.

Another thing should be noted in connection with Percy's "Canopie". Near the end of the play we find the words: "Here they shutt both [i. e., Orion and Hysiphyle] into the Canopie Fane or Trophey together with the banquet"' (p. 187). We can understand how a person of Percy's temper might call a chapel a temple or fane, but not even Percy's originality would seem to justify the use of the word "Trophey" as a synonym for "Faery Chappell". There is only one possible motive for such procedure. On page 100 Hysiphyle says to Orion:

"Will you enforce us? our cause not yet hearde?

My Lord, fore I do loose my right, I will

Use all the Points of woodmanship I have

Gainst you, win the Crown weare you it and mee,

And loe, in pawn, I hurle him up our Tropheye."

And in the margin are written the words: "She hurld her ghirlond Imperiall up to Front of the Fane or Chappell'. It may be urged that by some extraordinary mental process Percy eighty-nine pages further on had these lines in mind when he wrote the word "Trophey". This, however, would hardly explain why he had the characters "shutt in the Trophey", since on page 183 the "Imperiall Ghirlond" had been removed from the front of the chapel and placed on the head of Orion.

An explanation of what Percy really had in mind when he wrote the direction may be ventured. He was trying to describe the rear of his stage, that is, a large opening surmounted by a balcony and flanked by two smaller openings. The "trophees" or triumphal arches erected at the coronation of the sovereigns or on similar occasions admirably fit such conditions. At Elizabeth's coronation, for example, a pageant or arch extended from one side of the street to the other. "And in the same pageant was devised three gates all open, and over the middle part thereof was erected one chaire or seate roiall", etc. Across the front of the pageant was written 
its title..6 This was at Cornehill. "Against Soper lane was extended from the one side of the street to the other, a pageant which had three gates all open; over the middlemost whereof were erected three severall stages, whereon sat eight children, as hereafter followeth", etc. ${ }^{2 i}$ The queen and her train passed through the middle and largest gate. When James I entered London in 1603 , at Cheapside stood a "stately entraunce into which was a faire gate, in height 18 foote, in breadth 12 ; the thicknesse of the passage under it being 24 . Two posternes stoode wide open on the two sides, either of them being 4 foote wide, and 8 foote high". ${ }^{28}$ The Dutch pageant on the same occasion ${ }^{29}$ was similar, the central gate measuring $12 \times 18 \mathrm{ft}$. with "two lesser posternes . . . . . for common feete, cut out and open'd on the sides of the other". If it be objected that such structures were not called "Trophees", then I refer the reader to Dekker's account of the "Italian trophee" erected at James I's entrance,,$^{30}$ or to his words regarding the Dutch pageant referred to above: "Above which (being the heart of the trophee) was a spacious square roome, left open, silke curtaines drawne before it". ${ }^{31}$

Perhaps "Fane" was also used as a descriptive word to apply to the background of the stage. Percy's position and the stage direction above imply that he knew Greek. Possibly the skene of the Attic theatre, usually penetrated by three openings and frequently representing a fane or temple in Greek tragedy, flashed into his head, but the more suggestive "trophey" was considered a necessary addition for clearness.

Other descriptive words used in connection with the rear stage are perhaps extant. In 1598 Florio writing for Englishmen defined scena in his dictionary as "a skaffold, a pavillion, or forepart of a theatre where players make them readie, being trimmed with hangings, out of which they enter upon the stage". Florio

${ }^{28}$ Holinshed, IV, 163.

27 Ibid., p. 165.

${ }^{28}$ Dekker's Account of Entry of James, Nichols, Prog. of Eliz., ed. 1805, III, 61.

${ }^{29}$ Ibid., 56.

${ }^{80}$ Ibid., 54.

31 Ibid., 57. For other cases see Gilbert Dugdale's Time Triumphant in Nichols, Prog. of James I, I, pp. 417, 418, 419. 
probably had the English theatre in mind, ${ }^{32}$ the canopy of Perey and Marston. Years before, Palsgrave had used the word "scene" in its old sense of dressing-room, or booth, when in the Prologue to his Acolastus he wrote (cf. N. E. D. under "scenish"): "The settying forth or trymming of our scenes, that is to saye, our places appoynted for our players to come forth of". About 1520 the author of The englysshe Mancyne apon the foure cardynale vertues spoke of "a disgyser yt goeth into a secret corner callyd a sene of the pleyinge place to chaunge his rayment", ${ }^{33}$ Perhaps some idea of what Florio meant by hangings at the "forepart" of the stage is brought out by Heywood in his Apology for Actors (p. 18), where he has Melpomene to say that the Golden Age was a time

"Fit for you bards to vent your golden rymes.

Then did I tread on arras; cloth of tissue

Hung round the fore-front of my stage."

Two late cases of the word "scene" in much the same sense that Florio seems to have used it as applying to the part of the tiringhouse behind the curtains are probably to be found. Dekker's If This Be Not a Good Play (pub. 1612, as lately acted at the Red Bull) has the direction, "Narcisso stepping in before in the Scene, enters here". This direction clearly means that Narcisso after having been on the rear stage ("scene") for some time passes to ("enters") the front stage. Brome's Joviall Crew (pub. 1641 as acted at the Cockpit) contains the direction, "He opens the scene; the Beggars are discovered in their postures". Scene in the later sense of curtain or partition was probably pretty common when this play was presented, but in view of what has preceded, it is possible to interpret the words to mean that the curtains before the "scene" (rear stage) were drawn.

Percy's "Canopie" and Florio's "pavillion" are both good terms to apply to a recess located beneath a roof or balcony and shut off from the view of the audience by arras or curtains. This being true, there is always the possibility that when stage directions refer to $a$ canopy, the author has in mind the space beneath

as of course he may have had in mind the draped platforms of early Italian pro. vincial actors, but certainly not the various 16th century theatres erected for court and church festivals after the model of Vitruvius. Cf. Flechsig, Dekoration der Modernen Bühne in Italien, passim; Bapst, Essai sur Histoire du Théatre, pp. 245 ff.; Mantzius Hist. of Theatrical Art, II, 342.

Mod. Lang. Quarterly, vi, 145. 
the balcony - an ordinary feature of playhouses - and not a separate stage property. And Florio's "pavillion", apparently used of stages in general in 1598, as well as Percy's "canopie", cannot be well applied, it should be noted, to the mimorum aedes of the Swan sketch.

Not only were canopies employed in the London theatres, but it is pretty certain that separate structures for shops, ete. were also used. $^{34}$ Even their use does not show, howerer, that a regular stage curtain was lacking. The rear stage was primarily designed to take the place of such structures, thereby keeping down expenses and at the same time allowing adequate presentation. But when it was necessary or desirable to employ a shop or stable in addition to the space behind the curtain, then a shop or stable was employed.

Neuendorff's argument for a vorhanglose Bühne on the basis of the pictures is not convincing. The Red Bull picture is of no significance in this connection. There is surely no reason for assuming, as Neuendorff does, that the Roxana picture represents a type of stage essentially different from that of the Messallina picture. Evidence has been given elsewhere ${ }^{35}$ for believing that the Swan in 1602 was provided with hangings and curtains, a matter that will receive further treatment in the following pages.

Stage directions are of little value in proving or disproving the existence of curtains. As Neuendorff recognizes (p. 59), such stage directions as "enter in a bed", "a bed thrust forth", do not in any sense prove the absence of a stage curtain. Many examples of this "crudity" can be found in extremely late plays. As Albright remarks (pp. 140-6), such directions may in many cases at least denote the placing of the bed on the rear stage or the actor's tendency

${ }^{34}$ Reynolds (Some Principles,, , 20, note) has cited probable instances of this in Histriomastix, Arden of Feversham, and Bartholomew Fair. Regarding this last play, we at least know that when it was acted at court separate structures were used, for in the Pipe Office Records for 1614-15 occurs the entry: "Canvas for the Boothes and other necessaries for a play called Bartholmewe Faire" (cited by Reyher, p. 382, note). The Roaring Girl calls for three shops in a "rank". We recall in this connection Henslowe's "Belendon stable" [Belendons table?] and " $i$ whell and frame in the Sege of London". What is this frame? Perhaps the rather large sum of 20s. lent by Henslowe on Oct. 23, 1602, to John Thare "to paye unto the paynter of the propertys for the playe of the iii brothers" (Greg. I, 184) refers to the painting of canvas stretched on frames.

${ }^{35}$ Mod. Phil., Jan., 1912. 
to present his action as far forward as possible. ${ }^{38}$ The bringing in of banquets proves nothing one way or another. Banquets were regularly "brought in" in actual Elizabethan life.

That definite references to curtains in stage directions are comparatively rare is quite true, but again this does not prove their non-existence. It does not prove that they were not employed even in plays where no reference is made to them. The existence or non-existence of curtains is surly not to be determined on the basis of stage directions. There is, I admit, always a presumption against drawing a curtain unless a direction bids one do so; and I heartily approve of Reynolds's objection to the regular playing back and forth of curtains called for in Albright's system of staging. No one, however, will deny, I believe, that numerous cases of the operation of curtains are entirely unnoted either in directions or dialogue. After opening they are frequently closed without any reference to the process. One example will make this clear. At the beginning of II, i, of Lord Cromwell, occur the words, "Cromwell in his study" (i. e. discovered). In III, 2, "Hodge sits in the study" (before the curtains are opened). At line 126 the governor says, "Goe draw the curtaines", and Hodge is discovered writing a letter. The curtains have surely closed since opening at the beginning of II, i, although there is nothing to that effect in stage-direction or text. Somewhat different are such scenes as IV, 3, of the first part of $E d w a r d I V$, where at the end of the scene Shore's wife is sitting in the shop while he is standing by. The scene closes with the words of the wife:

"I prithee, come, sweet love, and sit by me.

No king that's under heaven I love like thee."

Surely the very domestic Shore did not refuse this invitation. Nor is it probable that the couple left the stage to do their sitting, or sat for a moment and then made an exit.

Of more importance are cases of the curtains opening without stage-directions to that effect. Such vague remarks as "Cromwell in his study", "Let there be a brazen Head set in the middle of the place belind the stage", cases where "enter" means "dis-

The most pertinent direction in this connection that $I$ know is that in $V$, $i$, of The Lost Lady, "Enter the Moor on her bed, Hermione, Phillida and Irene. The bed thrust out". "Enter" is obviously used in a general way here, as it is in I, 2, of A Shoemaker a gentleman, "Enter discover'd in a Shop", etc. Cf. also "Enter, an angell ascends out of the well", etc. (ibid., I, 3, 101). 
cover" ${ }^{37}$ are in a certain sense examples of this. Reynolds ${ }^{38}$ has pointed out that in Pericles "two almost certain discoveries are quite unnoted in the directions". At the beginning of the second act of The Battle of Alcazar Furies are referred to as sounding in a "cave", but that is all. In the "Plot" of the play, however, occur the words: "to them [1]ying behind the Curtaines 3 Furies". The whole situation as well as the phraseology of the direction indicates, as Neuendorff notes (p. 85), that the Furies were discovered in a situation. In $A$ Looking Glass for London, II, i, a similar opening of the curtains occurs. The well-known direction in Bussy D'Ambois, I, 1- "Table, chessboard, and tapers behind the arras", - the words at the conclusion of Tancred and Gismunda, Antonio's Revenge, V, 2, are other examples. In Endymion and Sir Clyoman and Sir Clymades a curtain was surely used although there is no direction to that effect. Other instances of this sort of thing can be cited, but these are sufficient, it seems to me, to justify an assumption of the operation of curtains when the situation demands it, although that operation may be entirely unnoted in stage directions or dialogue. The problem, of course, is to determine when the situation actually demands the opening or closing of curtains.

Again, Neuendorff is, in my opinion, too skeptical when he expresses a doubt (p. 86) whether the reference in Tatham's prologue to spectators casting various objects against the curtain at the Bull necessarily refers to the stage curtain. The words in the prologue to Cynthia's Revels, "Slid the boy takes me for a piece of perspective . . . . or some silke cortaine, come to hang the stage here", he similarly regards as indefinite. "Curtain", he remarks, "ist nicht ein ganz sicherer, eindeutiger Ausdruck, wenn er nicht durch Angabe der Funktion verdentlicht wird". To be sure the actual function of the curtain in these two cases is not specified, but there seems to be no objection to giving the natural interpretation to the word in both instances, when curtains are obviously referred to as the ordinary and accustomed part of a theatre. Chamberlain's allusion to the curtains at the Swan in 1602 is a similar case.

\footnotetext{
${ }^{37}$ Reynolds, Some Principle8, I, 19: Creizenach, Geschichte, IV, 422. It is certain that "exit" was similarly used in a loose way. Cf. Antonio's Revenge, V, 2, "The cur. tains being drawn, exit Andrugio", "The Curtains are drawn, Piero departeth". In both cases the actors leave the stage after the curtains are closed.

as Mod. Phil., IX, 52.
} 
The Careless Shcpherdess (pr. 1656) ${ }^{39}$ contains the lines:

"There is ne'er a part

About him but breaks jests.-

I never saw Reade peeping through the curtain,

But ravishing joy entered my heart."

One determined to prove the accuracy of the Swan sketch might restrict this passage as referring to the late Blackfriars, ${ }^{40}$ or imagine Reade peeping through bed curtains. Similarly one could arbitrarily restrict Sir Walter Raleigh's words to the court stage:

"What is our life? The play of passion.

Our mirth? The music of division:

Our mothers' wombs the tiring-houses be,

Where we are dressed for life's short comedy.

The earth the stage; Heaven the spectator is,

Who sits and views whoso'er doth act amiss.

The graves which hide us from the scorching sun

Are like drawn curtains when the play is done." 41

It is virtually certain, however, that Sir Walter was taking his figure from general theatrical conditions. Drummond of Hawthorndon in his Cypress Grove Walks ${ }^{42}$ uses the old figure: "Every one cometh there to act his part of this tragi-comedy, called life, which done, the courtaine is drawn, and he removing is said to dy"' "Shut up" in Elizabethan English is a rather general expression, but it is likely that Day had in mind the custom of closing the stage curtains at the conchusion of a play when he has Aspero to end Humour Out of Breath with the words:

"And so shut up our single comedy,

With Plautus phrase: Si placet, plaudite."

A general practice, and not the opening or closing of specific curtains in a specific theatre, is in all probability referred to in the Chorus preceding II, 1, of Heywood's Edward IV (second part) :

"Now do we draw the curtain of our scene,43

To speak of Shore and his fair wife again."

Such quotations, of course, do not aid much in proving a stage curtain at the Theatre or Globe. They are given to show that when

s Collier, Bibliog. Catalogue, II, 382.

${ }^{10} \mathrm{Cf}$. The Stage players complaint in a pleasant Dialogue between Cane of the Fortune and Reed of the Friers (1691).

4 J. Hannah, Works of Raleigh, p. 29.

2 Quoted in N. E. D. under "curtain".

* Is scene used here in sense of rear-stage? Cf. abore. 
Elizabethans spoke of eurtains in a playhouse, they probably did not have in mind curtains to the upper stage, bed curtains or canopies.

When such things as have been referred to above are considered, together with the evidence for curtains which Nenendorff has collected, there is surely no reason for believing that the vorhanglose Bühne was ever a wide-spread type, that it represents an experiment in stage construction as late as the building of the Swan, or that such a type is to be used in tracing a development in the methods of Elizabethan staging. There is no reason for believing that it existed at all in Elizabethan theatres.

Apparently realizing the common use of curtains in London theatres and carrying out his theory of various experimentations in theatre building, Neuendorff conceives a special form of stage to accommodate such scenes as David and Bethsabe, I, 1, Ford's Love's Sacrifice, V, 1, Browne's Novella, IV, 1. "Man nehme", he writes, "die Swanbühne, statte sie mit einem Vorhang da aus, wo jetzt die beiden Säulen stehen, und denke man nun die ganze Bühne so weit zurückgerückt, dass der Vorhang dort hängt, wo jetzt das Tiring-house beginnt (dabei ist noch gans von den Türen abgesehen). Möglich ist ja auch, dass für solche Scenen gelegentlich auch die Swanbühne einen Vorhang erhielt"' (pp. 92-93).

That such a form of stage existed is at least conceivable. Large curtains were used at court; possibly, front curtains existed in private theatres. It is hardly probable, however, that such a stage was suggested by such a one as that shown in the DeWitt sketch, or that curtains were ever suspended between such pillars as are therein revealed. Nor is a special type of stage necessary to explain the scenes cited above. They are admirably explained by oblique doors or the "canopy" stage. Reynolds's idea that in such scenes the actors need not actually see those on the inner stage is in itself a satisfactory explanation. ${ }^{\mathbf{4 4}}$

Neuendorff is by no means an alternationist; he would not hang permanently a curtain between the pillars of the Swan type of stage; but the fact that curtains are found at the Swan in 1602 and the great importance which he attaches to the DeWitt sketch necesFaust.

44 Some of us have no doubt seen the vision of Margaret appear directly beneath 
sitate a discussion of the drawing, especially the nature and location of the front pillars.

Is the DeWitt sketch to be accepted as representing the real nature and position of the shadow and pillars at the Swan? If so, were the curtains mentioned by Chamberlain in 1602 suspended between these pillars? And if so, was this type of stage at all common during the Elizabethan period? These are the questions that now demand our attention.

As we have seen, Neuendorff groups the Fortune, Swan, Globe, and Hope under the same general type of stage; and on page 25 he asserts that, probably after the analogy of the Swan, the "heavens" supported by the pillars covered only a part of the lower stage at the Fortune and Globe. Whether he regards these theatres as being substantially like the Swan, or whether he considers them to be examples of the modified Swan stage mentioned above, I am unable to say. I will say, however, that there is no reason for believing that the DeWitt sketch in the matter of shadow and pillars represents conditions as they existed before or after the building of the Swan. In all probability it does not represent conditions as they existed at the Swan.

In a recent article ${ }^{45}$ John Corbin has printed a drawing of the Fortune by George Varian, which represents, it seems to me, more truly the real structure of the shadow or "heavens" than does any drawing that has yet appeared. Under the influence, perhaps, of the DeWitt sketch, the designer of the "typical" Elizabethan stage in Albright's The Shaksperian Stage represents the shadow as a sort of penthouse covering only a small portion of the projecting stage. ${ }^{46}$ In Varian's drawing, however, the shadow is much larger and higher, and it virtually covers the entire stage. I believe that in some theatres at least the "hut" projected further into the yard than is shown even in Varian's drawing, and that at the Fortune, Globe, Rose and Hope, perhaps at the Curtain and Theatre, the shed attached to it extended practically to the front edge of the stage. My reasons for this view follow.

In the contract for the Fortune ${ }^{47}$ it is specified that there is

${ }^{45}$ Century Magazine, Dec., 1911, p. 261. Varian's drawing is followed in this respect by Stouer in the semi-monthly magazine section of the Chicago Tribune for April 4, 1912.

46 This is also true of other drawings, as those of Godfrey and Schelling.

${ }^{47}$ Henslowe Papers, ed. Greg, p. 5. 
to be "a shadowe or cover over the saide Stadge", which stage is "to extende to the middle of the yarde of the saide howse". "Over the saide Stadge" and "coveringe of the saide stadge" do not, of course, necessarily mean that the cover is to extend over the entire stage, but that is at least the most natural interpretation to give to the expressions. The same is true of Cotgrave's definition (French Dictionary, 1611) of Volerie as "a place over a stage which we call the Heaven". Even the words "shadow" and "cover" suggest that the entire stage, and not a part of it, was to be covered. "Heavens"' suggests the same thing, as is illustrated in Cotgrave's definition of "Dais", for example, as "a cloth of estate, canopie, or Heaven, that stands over the heads of Princes thrones". In his preface to the 1591 edition of Astrophel and Stella ${ }^{48}$ Nash wrote: "here you shall find a paper stage strewed with pearl, an artificial heaven to overshadow the faire frame". "Overshadow the fair frame" is perhaps more definite; and Nash, be it remembered, was apparently taking his figure from existing conditions at the Curtain and Theatre. ${ }^{49}$ At the Hope the "heavens" were to be constructed "all over the saide stage"; and if the picture of the second Globe is of any service in this connection, it is apparent that in this theatre, too, the "heavens" must have extended "all over" the stage, since the foremost of the two huts surely extends to fully half the distance of the yard.

And why assume that practical Englishmen in building shadows for protection should build that protection over half the stage rather than over all of it? One of the reasons, says Gosson, why Life in The Play of Plays chose Commedies for his companion was "because he may sit out of the raine to viewe the same, when many other pastimes are hindred by wether." When "commedies," then, were presented at public houses during rainy weather, why believe that actors in their gorgeous and expensive costumes were either exposed to the weather or else confined to the rear portion of the stage?

There is perhaps another reason for believing that the "hut" projected well forward and that the "cover" attached to it was not a mere penthouse, but a structure parallel to the stage floor and

48 Lee, Eliz. Sonnets, I, 5.

- The Rose certainly had a "heaven", (Henslowe's Diary, ed. Greg, I, 4). As Greg notes, there is no evidence for supposing that the Rose was built before 1592 . 
practically as high as the ceiling of the upper gallery. The term "hearens" doubtless had a double significance. In addition to being a cover or canopy over the stage, it was a "heaven" in the sense that it was fitted up, perhaps very elaborately, to represent the firmament.

The representation of heaven by painted canvas stretched overhead was no new thing in 1576. Among the items, for example, delivered on July 4, 1470, by "Master Canynge" to Nicholas Petters, vicar of St. Mary Redeliffe, was a new sepulchre gilt with gold, and among other things belonging to it, "Heaven, made of timber and stain'd cloth", and "The Holy Ghosht coming out of Heaven into the supulchre",.50 The masqueing and banqueting houses of the time were regularly covered with canvas painted like the heavens. The one erected in the courtyard of the Bastille in $1519,{ }^{51}$ for example, was covered with "an awning of blue canvas well waxed and powdered with gilt stars, signs and planets", while Henry VIII's "theatre", erected at Calais in 1520, had a roof of azure-colored canvas "decorated with gold stars and planets of looking glass". ${ }^{2}$

"Heavens" in pageants are not unknown. At the coronation of Edward VI "towardes Chepe there was a doble scafolde one above the other, which was hanged with cloth of golde and silke, besydes rich arras. There was also devised under the upper scafolde an element or heaven, with the sunn, starrs, and clowdes very naturally. From this clowde there spred abroad another lesser clowde of white sarsenet, frenged with sylke, powdered with sterres and bemes of gold, out of the whiche there descended a Phenyx downe to the nether scafolde." A "crowne imperiall" was also "brought from heaven above, as by ii angelles", and placed upon a lion's head. ${ }^{53}$

At court we hear of wages as early as 1564 for work upon "divers devisses as the heavens \& clowds". In the accounts for 1574-5 "Dubble gyrtes to hange the soon in the Clowde" are men-

60 Park, Nugae Antiquae, I, 12-13.

61 Cal. State Papers, Venetian, 1509.1519, p. 485.

Ibid., 1520-26, p. 32. For other examples see Oal. State Papers, Venetian, 152733 , pp. 59.60; Feuillerat, Doc. of Revels, pp. 163, 167; Holinshed, Chronicle, ed. of 1808, IV, 434-5.

Literary Remains of Ed. VI, I, p. cclxxxvi. 
tioned, ${ }^{54}$ while in the same year John Carow is referred to as furnishing "heaven, hell, \& the devell \& all the devell I should saie but not all". ${ }^{55}$

Nash in 1591 spoke of an artificial heaven overshadowing his fair stage. Henslowe in 1598 mentions the cloth of the sun and moon; three suns apparently performed in Third Henry VI, II, 1, five moons in The Troublesome Reign; and in the Play of Thos. Stucley "with a sudden thunder-clap the sky is on fire and the blazing star appears". One is reminded, too, of the "Two pieces of blue linen cloth with lyre in them, 67 yds." mentioned among the playing parcels of Rastell about $1530 . .^{56}$ At a much later date Heywood in his Apology for Actors (pp. 34-5), describing Caesar's theatre in very Elizabethan terms, refers to "the covering of the stage, which wee call the heavens (where upon any occasion their gods descended), were geometrically supported by a giant-like Atlas, whom the poets for his astrology feigne to beare heaven on his shoulders; in which an artificiall sunne and moone, of extraordinary aspect and brightnesse, had their diurnall and nocturnall motions; so had the starres their true and coelestiall course".

In the same writer's Brazen Age, V, 2, a hand descends from "heaven" in a cloud and "from the place where Hercules was burnt, brings up a starre, and fixeth it in the firmament". Brome (Antipodes, 1638) mentions "our planets and our constellations" as ordinary occupants of the property room. ${ }^{57}$ Milton in his Astrologaster (1620) speaks of the actors at the Fortune making "artificial lightning in their heavens". And finally R. M. in his "Character" of a player (1629) has the illuminating passage: "If his action prefigure passion, he raves, rages, and protests much by his painted heavens, and seems in the height of this fit ready to pull Jove out of the garret where perchance he lies leaning on his elbows, or is employed to make squibs and crackers to grace the play" (Morley, Character Writings, pp. 285-86).

Now such properties were obviously intended to be seen by the

54 Feuillerat, Doc. of Revels, p. 240.

6 Ibid., p. 241.

${ }^{68}$ Pollard, Fifteenth Cent. Prose and Verse, p. 213.

ot When scenes were actually presented in hearen the upper stage was probably used. Cf. Woman in the Moon, Holiday's Technogamia (Collier, Hist. of Dram. Lit., III, 175), etc. 
entire audience, and not by a part of it, as would have been the case beneath such a shadow as is shown in the DeWitt sketch with its impossible dip. Perhaps it should be mentioned, too, that the gods and thrones that descended from and ascended to this "heaven" were apparently spectacular features, which, as Jonson puts it, especially pleased the groundlings. ${ }^{58}$ Height was necessary for the successful carrying out of such devices. Those sitting in the upper gallery would hardly receive the full benefit of such operations on such a stage as is shown in the Swan sketch.

Not only did gods and goddesses descend from above, but the heavens themselves, as it were, descended in the form of cloudsa spectacular feature that would seem to call for considerable space above the stage as well as height. And clouds, it is to be remembered, were, like curtains, a commonplace in London theatres. They had been descending in Italian, French ${ }^{59}$ and English mystery plays ${ }^{60}$ for years before Burbage built his theatre, in city pageants, ${ }^{61}$ and at court. ${ }^{62}$ They were not unknown to special outdoor entertainments $;^{63}$ and their apparent frequency in miracle plays is

${ }^{58}$ Reynolds (Mod. Phil., IX, 11) asks if descending gods, etc., were possible in privste theatres. There seems to be no difficulty here. The problem was the same as that which confronted the performers at Court where gods certainly did descend from aloft. Instead of descending from a "hut", in private theatres they no doubt came down from rooms above the stage. It is possible that actors even in their provincial tours managed to have persons descend from aloft. In the Barnstaple records for 1593.4 oc curs the entry: "paid for amendynge the seelynge in the Guildhall that the Enterlude players had broken downe there this year . . . . vi d" (Murray, Eng. Dram. Companies, II, 198.9). It is even probable that the cover to the stage in private houses was called the "heavens". Heywood and Cotgrave seem to be describing general condi. tions in England. And if we accept the view that the prologue to Chapman's All Fools was written for Blackfriars, then the following lines would argue that this theatre had a "heaven":

\footnotetext{
"The fortune of a Stage (like Fortunes selfe)

Amazeth greatest judgments; and none knowes

The hidden causes of those strange effects,

That rise from this Hell, or fall from this Heaven".
}

The place beneath the stage was regularly called "Hell". Cf. Dekker's News from Hell, 1606, ed. Grosart, p. 92, where it is said that "Hell" is under "everie one" of the London stages. See same volume, p. 139.

${ }^{6}$ Stuart, Stage Decoration in France, pp. 110, 146; Cohen, La Mise en Scène dans le Théatre Rcligieux Français, pp. 153.4.

${ }^{60}$ Perhaps they were not always possible in English mysteries. At least this is implied in the stage direction in the third play of the Chester Cycle: "Et primo in aliquo loco sive in nubibus, si fieri poterit, loquatur Deus sd Noe extra Archam". So in the "Domesday": "descendet Jesus quasi in nube, si fleri poterit".

21 Hall, Chronicle, pp. 640-1; Nichols, Prog. of Eliz., ed. 1788, I, pp. x, 8.

2 Doc. of Revels, pp. 116, 240, 307.

6a Cunliffe's ed. of Gascoigne's Princely Pleasures, pp. 107, 116. 
attested by Palsgrave's words:64 "Of whyche the lyke thyng is used to be shewed now adays in stage-playes, when some god or some saynt is made to appeare forth of a cloude: and succoureth the parties which seemed to be towardes some great danger, through the Soudan's crueltie', That they were regular features at public theatres as early as $1578-9$, is made probable by the entry in the Revels Accounts for that date: ${ }^{65}$ "ffor a hoope and blewe Lynnen cloth to mend the clowde that was Borrowed and eut to serve the rocke in the plaie of the burnyng knight and for the hire thereof and setting upp the same where it was borrowed . . . . x s.", It was "borrowed', I venture to say, from Burbage's theatre; and the "setting upp the same where it was borrowed" consisted in replacing it in the "heavens" of the Theatre.

Just how large the clouds ${ }^{66}$ were that descended and rose in the public theatres I am unable to say, but there is good reason for thinking that they were of sufficient size to require considerable space in the "heavens" outside the front edge of the balcony; for it is pretty certain that clouds did not descend from the balcony but came straight down from heaven. This was true even at court until the time of Hymenaei, since at the performance of this piece, observed a spectator, the clouds did not descend in the usual and commonplace manner, like a bucket in a well, but came down in a gentle and graceful curve. ${ }^{67}$

Such are the indications that the "hut" extended well forward with a large shadow or cover at its outer edge, a cover which was parallel or virtually parallel to the platform below, which was as high as the ceiling of the upper gallery, and which extended practically to the front edge of the platform below. On such a stage the hanging of curtains between the front pillars is an obvious absurdity.

${ }^{64}$ Acolastus, 1540. Quoted in Malone-Boswell Shakespeare of 1821, III, 88, note.

${ }^{\text {as }}$ Feuillerat, Doc. of Revels, p. 308.

${ }^{e \theta}$ If it is possible to interpret the expression that the cloud was cut "to serve the rocke" as meaning that a large hole was cut in it so that it could descend over the rock, then the property must have been a large affair. "A scalling Ladder that served at the Rock" is referred to in connection with the play (Doc. of Revels, p. 307), while among the parcels "bestowed in and about a rocke at the courte for a plaie enacted by the Earle of Warwickes servaunts" are included "Longe sparre poles of ffurre", "Dobble quarters iii", "single quarters ii", "Deale bourdes xxxii", "Elme bordes 153 foote". (Ibid., pp. 306).

${ }^{7}$ Reyher, Les Masques Anglais, p. 372. 
The DeWitt sketeh, to be sure, does not show such pillars and "heavens". Nor does it show the eurtains which the Swan possessed. And granting that the pillars at this particular theatre were set about midway of the stage, as shown in the drawing, even then the curtains cannot be suspended between the pillars, as Reynolds, Archer and Child have shown.

The difficulty here cannot be evaded by saying that the Swan was an entirely different type of stage from those of the regular playhouses, that it was constructed primarily for variety entertainments, or that it was an amphitheatre in the stricter sense, such a structure as apparently was to have been built later in LincolnInn Fields had not the patent been eancelled by James I. Professor C. W. Wallace has recently shown ${ }^{68}$ that it was unquestionably used for plays at an early date. DeWitt's calling it the "largest and most beautiful" of the London theatres shows nothing one way or the other, but the words of John Weever in $1599,{ }^{69}$ while rather vague, seem to be another reference to the Swan as a place for plays :

\footnotetext{
"Rome had her Roscius and her Theater, Her Terence, Plautus, Ennius and Meander, The first to Allen, Phoebus did transfer The next, 'Thames Swans receiv'd fore he coulde land her, Of both more worthy we by Phoebus doome, Then t'[o] Allen Roscius yeeld, to London Rome".
}

Another explanation is surely necessary. Child ${ }^{70}$ after a very able discussion of the Swan shadow and pillars concludes as follows: "The fact is significant that, just as the Hope, though planned on the lines of the Swan, was to be built of wood, not flint, so, in the contract with the builder, it is directly stated that he shall 'also builde the Heavens all over the saide stage to be borne or carried without any postes or supporters to be fixed or sett uppon the saide stage'. It is possible, therefore, that the pillars of the Swan were as the drawing shows them, and that the pentroof covered half or nearly half the stage; but that the plan was found inconvenient, was confined to the Swan and was discarded by Henslowe when he built the Hope".

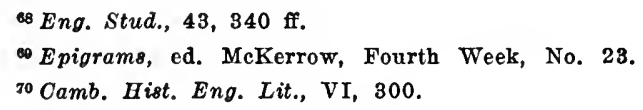


As Child says, the hitting upon such an unhappy and apparently such an uncommon plan is decidedly strange. And as the Swan was certainly not built of flint but of very skillfully painted wood, ${ }^{71}$ and as there is no contrast, expressed or implied, between the materials that were to compose the two theatres, the possibility expressed by Child loses its force. Indeed, if one interprets the passage quoted above in connection with what immediately precedes and follows, one is certainly inclined to say that in 1614 the pillars had been removed from the Swan; that the "heavens" at the Hope were to cover the entire stage and yet be borne without pillars, as was the case at the Swan.

It is more likely, however, that the passage in question is not intended to emphasize any similarity to, or deviation from, the Swan stage, but is intended to stress the fact that although the "heaven" is to be a large structure covering the entire stage, it is nevertheless to be supported without the aid of pillars. This problem was solved by attaching the shadow to the roof above the upper gallery, as is shown in the picture, "The Hope in 1647 ", printed facing page 238 of Ordish's Early London Theatres. The discarding of the front pillars, ${ }^{72}$ which had never played a part in Elizabethan staging, was necessitated by the fact that the house was designed not only for plays but also for bear-baiting, a sport that would have been rendered practically impossible by pillars resting upon the front of a fixed stage, as was the case at the Swan, Globe and Fortune. ${ }^{73}$

Rather than believe that the Swan was a radical deviation in stage architecture, I prefer to believe that the DeWitt sketch misrepresents the nature of the shadow and front pillars as it mis-

71 The walls of the banqueting-house built at Westminster in 1581 "were closed with canvas, and painted all the outsides of the same most artificiallie with a work called rusticke, much like to stone" (Holinshed, Chronicle, IV, 434). Or perhaps the outside of the walls of the Swan were plastered. Cf. C. W. Wallace, Children of the Chapel, pp. 30-32.

${ }^{2}$ Neuendorff, p. 21, in defending the DeWitt drawing says that whereas the Hope contract states explicitly that the "heavens" are to be "carried without any postes", yet the words later in the same document-."and to make turned cullumes uppon and orer the stage"-can only mean that "auch das Hope Theater Säulen hatte, genau wie das Swan Theater, wie eben diese Art ron Bühnen solche Säulen vorn auf der Bühne zu haben pflegten". The columns upon the stage, however, were not placed on the front stage. Nor can they be regarded as a vestige of the "Swan type" of stage. They were the posts supporting the upper stage.

${ }^{73} \mathrm{Cf}$. below. 
represents other features of the actual Swan theatre. And if I were asked to make my contribution to the conjectures that have been made regarding the manner in which the DeWitt sketch was fashioned, I should be inclined to say that the apparent dip of the shed before the "liut" was not intended to represent a slanting roof, but is a crude attempt of one sketching from the point of view of the upper gallery, or some higher point, to give perspective to the structure. Since this method of showing perspective, however, if entirely carried out, would have resulted in the hiding of the stage itself, it was therefore abandoned, a process necessarily resulting in a curtailed shadow and the erecting of pillars near the middle of the stage.

And would such a guess be more absurd than to suppose that the builders of the "largest and most distinguished" theatre of its time deliberately constructed a more primitive and less convenient type of stage than that which was already in existence; and that this innovation in stage-construction, so impractical and inconvenient as to be discarded later, a stage on which the "firmament" was invisible to some, actors' costumes were exposed to the weather and curtains virtually impossible, served as a model, as it were, for the Globe and Fortune? If, as Neuendorff affirms, the late sixteenth century was an era of experimentation in theatre-construction and the author of the Swan sketch is to be trusted, then somebody obviously blundered when the most distinguished theatre of its day was built. Granting that it was Langley and his contractor, then we are certainly not justified in assuming that Peter Street and Henslowe, who had built the more "developed" Rose, Burbage and the rest all followed in their footsteps. The blunder, it seems to me, rests with the author of the drawing.

All this is merely an attempt to show what has been known for a long time: the Swan sketch, even if it be correct, cannot be used to prove the prevalence of the vorhanglose Bühne before 1603, or to mark any step in the development of Elizabethan staging or stage-structure. It is at most an astonishing exception. If this is true, if three entrances, ${ }^{74}$ upper stages, and stage curtains were apparently regular features of early theatres, there seems to be at least no a priori reason for thinking that the "alcove" or "can-

${ }^{74}$ Reynolds, Some Principles, I, pp. 7.8. 
opy" stage did not exist at the two earlier theatres as well as at the Rose.

I agree with Neuendorff that such a type of stage was the result of study and experience. There were, however, abundant opportunities for all these things long before Burbage built his theatre; there were abundant suggestions for such a form of stage, suggestions, too, which could hardly have failed to appeal to the wideawake Burbage, himself a carpenter. Before discussing these suggestions and the probable origin of the "alcove" or "canopy" stage - good a priori grounds for its early existence - it is necessary to discuss at some length the inn-yard in its relationship to the first regular theatres. 


\section{THE INN-YARDS AND THE EARLY THEATRES}

Speaking of the performance of plays at inns, Malone ${ }^{1}$ wrote early in the nineteenth century: "We may suppose the stage to have been raised in this area [the inn-yard], on the fourth side, with its back to the gateway of the inn, at which the money for admission was taken. Thus, in fine weather, a playhouse not incommodious might have been formed". Ever since this conjecture was made, it has been customary to regard the inn-yard as the regular and preferred place for public plays before the building of the first permanent theatres, and to see in it the structural original of these Elizabethan institutions. But was this actually the case?/That inn-yard influence in the construction of the early theatres is possible, I would of course not deny, but that the inn-yard was the favorite place for theatrical performances, or that it was structurally the original of the first theatres is at least questionable. The view that the inn-yard stage served as a model for that at the Theatre or Curtain is almost certainly untenable, as, I believe, the following pages will show.

At the beginning of this discussion it must be said that the presentation of plays in inn-yards cannot be questioned. The Act of the Common Council of Dec. 6, 1574, ${ }^{2}$ begins: "Whereas hearetofore sondrye greate disorders and Inconvenyences have beene found to ensewe to this Cittie by the inordynate hauntyinge of greate multitudes of people speciallye youthe, to playes, enterludes, and shewes namelye occasyon of ffrayes and quarrelles, eavell practizes of incontinencye In greate Innes, havinge chambers and secrete places adioyninge to their open stagies and gallyries", etc.

"Open stagies and gallyries" surely refers to the stage erected in the yard and to the galleries of the inn. All the evils of performances, however, were not confined to inn-yard performances, as is shown in the words, "allso soundrye slaughters and mayheminges of the Quenes Subiectes have happened by ruines of Skaffoldes fframes and Stagies, and by engynes weapons and powder used in plaies". 3 Nor does the passage first quoted necessarily mean that

1 Malone-Boswell, Shakespeare of 1821 , III, 72.

2 Malone Soc., Collections, I, 2, p. 175.

Ibid., p. 175. Is this a reference to mystery plays and pageants, or did the Council have in mind "skaffoldes" and "fframes" erected in the halls of inns or in the yard itself 8 
the majority of plays were being performed in inn-yards. This is shown by the numerous references to early plays in guild-halls, etc., ${ }^{4}$ and by the words in the document quoted above: "Be yt enacted . . . . that no Inkeper Tavernekeper nor other person what soeu' wthin the liberties of thys Cittie shall openlye shewe or playe nor cawse or suffer to be openlye shewed or played wthin the lous yarde or anie other place . . . . . And that no person shall suffer anie plays enterludes Comodyes, Tragidies or shewes to be played or shewed in his hous yarde or other place". ${ }^{5}$

A decree of May 12, 1569, reads: "Forasmuch as thoroughe the greate resort, accesse and assembles of great numbers of multitides of people unto diverse and severall Innes and other places of this Citie, and the liberties \& suburbes of the same, to thentent to here and see certayne Stage playes, enterludes, and other disguisinges, on the Saboth dayes and other solempne feastes commaunded by the church to be kept holy, and there being close pestered together is Small romes, specially in this tyme of Sommer, all not being [clene] and voyd of infeccions and diseases, whereby great infeceion . . . . may arise and growe [it is ordered] that no mannour of parson or parsons whatsoever, dwelling or inhabiting within this Citie of London liberties and suburbes of the same, being Inkepers, Tablekepers, Tavernours, hall-kepers or bruers, Do or shall, from and after the last daye of this moneth of May nowe next ensuinge, untill the last day of September then next following, take uppon him or them to set fourth, eyther openly or privatly, anny Stage play or Interludes, or to permit or suffer to be set fourth or played with [in] his or there mansion howse, yarde, Court, Garden, orchard, or other place or places whatsoever . . . anny mannour of Stage play, Enterlude, or other disgiusing whatsoever'". ${ }^{8}$

The objection that persons in plague time were "close pestered together in small romes" perhaps determined the phraseology of the letter of May 20,1572, to the Common Council, "written in favor of certein persones to have in there howses, yardes, or backe sydes, being overt \& open places, such playes, enterludes, Com-

4 Murray, Eng. Dram. Companies, II, passim.

- Malone Society, Collections, I, 2, pp. 176-77.

e Harrison, Desc. of Eng., ed. Furnivall, IV, 315-17. 
medies, \& tragedies as maye tende to represse vyce \& extoll vertwe ". And in view of what precedes, it appears that interior performances rather than performances in the open yards were regarded as particularly dangerous by the Privy Council, which decreed on June 22, 1600: "And especially it is forbidden that any stage plays shall be played (as sometimes they have been) in any common inn, for public assembly in or near about the city'.

Plays, then, were being presented inside taverns and inns as well as in the yards. ${ }^{8}$ Not giving this fact due consideration, some scholars liave too rashly concluded that the various references of the time to performances in or at inns refer in all cases to innyard theatricals. Child, ${ }^{9}$ for example, remarks that when Elizabeth came to the throne, "the usual places of public theatrical performances were certain innyards. An account written in 1628 enumerates five of these yards, where plays were publicly performed." And he mentions the Bell, Bull, Bell Savage, Whitefriars, "nigh Pauls". This is obviously a reference to a passage quoted by Prynne ${ }^{10}$ from Rawlidge's Monster Lately Found Out, which Halliwell had interpreted as referring to the "yards" of certain wellknown inns. ${ }^{11}$

The passage, however, does not speak of inn-yards, but of "the playhouses in Gracious-street", etc. Nor is it certain that Whitefriars and "nigh Pauls" were really inns. At least it should be noted that "Blackfriars", which Fleay, ${ }^{12}$ and others misled by the inn-yard theory, pronounced an inn, was far from such $;^{13}$ and that Paul's Children probably performed, not at an inn, but in the music room of St. Gregory's and the yard adjoining the Convocation House. ${ }^{14}$ Howe, too, writing about the same time that Rawlidge wrote, it should be remembered, says that five, ${ }^{15}$ and not eight, ${ }^{16}$

I Ibid., p. 318 .

8 The assertions in 1559 of Il Schifanoya and Paulo Tiepolo that undesirable plays were being presented in London taverns and hostels apparently have reference to interior performances (Cal. State Papers, Venice, 1558-1580, pp. 27, 65, 71.).

${ }^{9}$ Camb. Hist. Eng. Lit., VI, p. 282.

${ }^{10}$ Bistriomastix, pp. 441-42.

11 Illustrations of Shakespeare, p. 42.

${ }^{12}$ Hist. of Stage, pp. $36,367-68$.

15 Cf. Fevillerat in Shakespeare Jahrbuch, XLVIII, $81 \mathrm{ff}$.

14 Baker, Development of Shakespeare, pp. 45-46.

${ }^{15}$ Harrison, Desc, of Eng., ed. Furnivall, Forewords to Pt. II, p. 49.

18 Fleay (Stage, pp. 367-68) enumerates as inns regularly used for plays the Whitefriars, "nigh Pauls", Blackfriars, Bell, Bull, Bell Savage, Boar's Head and Cross Keys. 
common hostelries had been turned into theatres; while Stockwood, preaching in 1578 when the Theatre, Curtain and Blackfriars were in operation, asserted that he knew of "eighte ordinarie places in the Citie" where plays were presented. ${ }^{17}$

But even granting that Rawlidge's "playhouses" were inns, then is it at all certain that actors preferred to act in the yards of such structures rather than in the great halls? To be sure, one of Tarleton's Jests ${ }^{18}$ seems to point to a stage in the yard of the Bull. "At the Bull in Bishops-gate-street", we are told, "where the Queenes players often times played, Tarleton comming on the stage, one from the gallery threw a pippin at him." "Gallery" certainly implies the gallery around the yard, though the casting of an apple by a fellow who had a "quean to his wife" perhaps does not agree with the accepted view that this gallery was reserved for the better class of spectators. Of more significance is the statement of Flecknoe ${ }^{19}$ in 1664 , that the early actors were "without any certain Theaters or set Companies, till about the beginning of Queen Elizabeths Reign they began here to assemble into Companies, and set up Theatres, first in the City (as in the Inn-yards of the CrossKeyes and Bull in Grace and Bishops-gate Street at this day is to be seen.)"

The lateness of this document and its vagueness make it of little value in our discussion. Flecknoe may possibly mean that "Theatres" had been recently set up and were, in 1664, being used for plays at the Bull and Cross Keys. The passage more probably means, however, that the "Theatres" erected in the yards of the Bull and Cross Keys, in the sixteenth century, were still to be seen. It is difficult to believe, however, that structures erected in such places would have remained in existence for over sixty years, ${ }^{20}$ including the destructive period of the Commonwealth. ${ }^{21}$ Certainly

${ }^{17}$ Harrison, Desc. of Eng., ed. Furnivall, IV, 335.

18 Sh. Soc. Pub., II, pp. 13-14. II, 92 ).

${ }^{19}$ Short Discourse of the Eng. Stage (Spingarn, Seventeenth Century Critical Essays,

${ }^{20}$ Fleas, Hist. of Stage, pp. 367-8, dates the Bull 1560-76, the Cross Keys 1589-94. That performances in inns were uncommon after 1600 is implied in the act of the Privy Council of June 22, 1600: "And especially it is forbidden that any stage plays shall be played (as sometimes they have been) in any common inn, for publick assembly in or near about the city" (cf. Malone, Soc. Collections, I, 1, p. 83). The large number of play. houses in use after 1600 implies also the infrequency of performances at inns.

${ }^{21}$ For the ordinance of 1647 for the destruction of playing places, see Hazlitt, Eng. Drama and Stage, p. 68 . For the destruction of theatres during the period, see Academy, Oct., 1882, p. 315 . 
this would not have happened had the inn-yard "theatres" been simple or removable structures. If Flecknoe's statement is to be accepted to prove the inn-yards to be the regular places for performances, then, it is to be also used to show that actors did not regard them as ready-made places for plays. Furthermore Howe's earlier statement that five common hostelries had been turned into theatres suggests improvements. Stockwood's statement in 1578, that there were "eight ordinarie places" in London for plays, together with Harrison's very uncertain passage ${ }^{22}$ describing the banishment in 1572 of plays out of London and the reflection that it is a sign of evil times "when plaiers wexe so riche that they can build suche houses", may indicate, too, that inn-yards were by no means regarded as ready-made theatres even before 1576 .

There is also one bit of evidence which seems to contradict Flecknoe's statement that the regular "playing place" at the Bull was located in the yard. On July 1, 1582, the Earl of Warwick wrote to the Lord Mayor asking permission for John David to play his prize at fencing at the Bull in Bishopsgate. On the 23 of the same month he again wrote complaining of the Mayor's ignoring his request. In the reply of the latter appear the words: "Onely I did restraine him from playeng in an Inne, $\mathrm{w}^{\text {ch }}$ was somewhat to close for infection and appointed him to playe in an open place of the leaden hall more fre from danger". Further on he writes: "I have herein yet further done for yor servante what I may, that is that if he obtaine lawfully to playe at the Theatre or other open place ont of the Citie, he hath and shall have my permition", etc. ${ }^{23}$ "Close" contrasted with "open" certainly implies interior performances in inns where conditions were especially favorable for the spreading of the plague. ${ }^{24}$ These passages, taken with those cited above, show in all probability what

${ }^{22}$ Description of Eng., ed. Furnivall. Cf. Furnivall's note, Pt. I, pp. liv-v. Cf. also Ordish, London Theatres, pp. 31-32, and Chambers in Acadeniy, Aug. 24, 1895.

${ }^{23}$ Malone Soc., Collections, I, 1, p. 57.

24 Maas (Englischen Theatretruppen, p. 28), is inclined to regard the Bull as the regular winter theatre of the Queen's Men on account of its being inside the city; and for the same reason he regards (p. 82) the Cross Keys as the winter headquarters of the Chamberlain's Men. It is not at all improbable that inns were especially desired for winter performances, not only on account of their proximity to the center of population, but also lecause their large halls were well adapted to plays in bad weather during winter. Performances at the open theatres, however, were common in winter. See Murray, Eng. Dram. Companies, I, 118, 126, 130; Halliwell, Illustrations, 44; Henslowe's Diary, ed. Greg, II, 58, etc. 
was the real condition of affairs; that is, actors performed sometimes in the yards, sometimes in the halls of the inns used regularly for theatrical purposes. When plays were to be presented during rain ${ }^{25}$ or darkness, the actors would naturally use the halls; when danger of the plague was imminent, they would repair to the "open" yards.

Another thing must be considered. It is apparent that when London players traveled in the prorinces, they preferred to set up their stages, not in the inn-yards, but in the torn-halls. This is well brought out in the various licences and petitions of the time. The licence of 1574 granted to Burbage and others does not specify that they are allowed to perform in town-halls; but that this was taken for granted and they set up their stages where they pleased, is implied in early documents. ${ }^{26}$ On Feb. 16, 1595, Lord Dudley issued a warrant to Francis Coffyn and Richard Bradshaw "to travel in the quality of playing and to use music in all eities, torns and corporations", requesting for them "the use of the Towne Hall or other place and countenance"..27 In Dec. 1606, Derby wrote the Mayor of Cliester regarding his players, adding in a postscript, "I rould request you to lett them have the toune hall to playe in the hall." 28

The licence to the King's Players in 1603 takes care to specify that the players are allowed to play, not only at the Globe, but "alsoe within anie towne halls or Moute halls or other conveniente places" in the outlying towns. ${ }^{29}$ This last phrase is repeated in the licence of 1604 to the Queen's Players, ${ }^{30}$ and in that of 1606 to Prince Henry's Players ${ }^{31}$ and that of 1609 to the Queen's Serrants. "S2 "Schoole horses" and "guildhalls" are added in the licences of 1610 and 1611 to the Duke of York's Players ${ }^{33}$ and

${ }^{25}$ In the early unroofed corrals in Spain, says Rennert, (Spanish Stage, pp. 28-29) a rain storm brought a sudden end to theatrical performances.

${ }^{26}$ Whitgift's Works, Parker Soc., III, 384; Third Blast of Retrait, (Hazlitt, Drama and Stage, p. 134).

27 Murray, II, 42.

${ }^{28}$ Ibid., p. 234.

${ }^{29}$ Malone Soc., Collections, I, 3, p. 264.

so Ibid., p. 266.

salone Soc., Collections, I, 3, p. 269.

s2 Ibid., p. 270 .

3 Ibid., p. 273. 
those of Lady Elizabeth, ${ }^{34}$ while that to the Elector Palatine's Servants ${ }^{35}$ in 1613 and the one to the King's Men ${ }^{36}$ in 1619 return to the older phraseology.

Now this specific mentioning of mote-halls and town-halls was due to the fact that actors desiring to perform in these places met with opposition by the various city governments. Fearing that city documents and other property might be damaged ${ }^{37}$ by such performances, the Nayor and his associates sometimes bought off licenced players, as was the case at Leicester ${ }^{38}$ in 1588 and 1589, where a resolution had been passed on November 17, 1582, that no players except those of the Queen and Lords of the Privy Council were to be suffered "to playe att the Towne Hall . . . . and then butt onlye before the Mayor \& his bretherne".39 Sometime between 1600 and 1622, the authorities at Worcester decreed "that noe playes bee had or made in the upper end of the Towne-hall of this city, nor council chamber used by any players whatsoever, and that noe playes be had or made in yeald by night tyme, and yf anie players be admytted to play in the yeald hall to be admytted to play in the lower end onlie". ${ }^{40}$ At a later date, 1623, a law was passed at Southampton, prohibiting further performances in the town-hall, since plays there were "very hurtfull troublesome and inconvenyent for that the table, benches and fourmes theire sett and placed for holdinge the Kinges Courtes are by those meanes broken and spoyled". ${ }^{41}$

Such records as these, as well as the numerous references to town-hall performances, show pretty clearly what the players regarded as the most desirable place in which to set up their stages. The remark of Chambers ${ }^{42}$ that after giving their first performance, "the Mayor's play", in the guild-hall, actors "would find a profitable pitch in the courtyard of some old-fashioned inn with its convenient range of outside galleries', does not seem to be borne

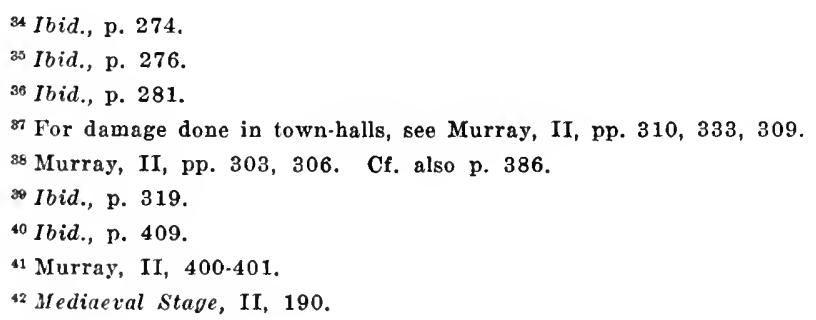


out entirely by the records. They obviously preferred the townhall and used it when possible. This may be partly due to the fact that night performances were rather frequent in the provinces. It may be, too, that plays at inns are not regularly mentioned in the city records; yet in spite of this possibility, one is, I believe, warranted in thinking that actors as a rule found it desirable to use the town-hall whenever possible, ${ }^{43}$ rather than to set up their stages in the inn-yards which have so often been called ready-made theatres for dramatic performances. Under such circumstances the question naturally arises whether after all the London theatres were so much indebted structurally to the inn-yard as has been generally supposed.

Some of the so-called "survivals" of the inn-yard period are of no value one way or the other in any attempt to show whether the inn-yard was or was not the structural original of the public theatre. The fact, for example, that both inns and theatres were provided with signs has no weight, when we remember that tenements, brewing-houses, stews, printing-shops, and other Elizabethan institutions were likewise equipped with these conveniences. The term "Yard", said to have been carried over into the theatre from its immediate prototype, is virtually the inevitable term to be applied to a ground space closed in on four sides. The inn as the usual adjunct of an Elizabethan theatre was, says Ordish, ${ }^{44}$ "a survival of the inn-yard performances". The Elizabethans, however, had a sense for business as well as the men who at the present time conduct bars as adjuncts to their theatres.

Other matters deserve more consideration. Getting his idea from the Swan picture, Mr. Appleton Morgan ${ }^{45}$ asserts that the putting of the entrance at the side of the stage instead of at the

43 It is worth while to note that the few cases of performances at inns recorded in the provincial towns - I have found no specific reference to an inn.yard performance were probably the result of the actors' inability to secure the town-hall (cf. Murray, II, $304,321.2,328$ ). With these records should be compared the statement of 1583 that Worcester's Men after having been refused the privilege of playing at Norwich, nevertheless "dyd play in their hoste his house" (ibid., 336), and the words concerning Lord Beauchamp's Men, who in 1590 met with the same difficulty, "yett notwithstanding . . . did sett up bills . . . and did playe in Xxe Churche" (ibid., p. 25). For plays in churches, see Murray, II, 25, 327, 381-2, 402; Chambers, Med. Stage, II, 191.

4 Early London Theatres, p. 158.

${ }^{45}$ Bankside Titus Andronicus, Introduction, p. 28. 
opposite end of the yard is "a blind following of the inn-yard custom'. But what he regards as the entrance to the Swan was not intended to represent such. The "ingressus" is simply a rough attempt to draw an entrance to the "orchestra". There is another one opposite to it.

The public theatres were roofless, we are sometimes led to believe, because roofs were lacking at their immediate prototypes; but surely the real reason that prompted Burbage and Langley to construct open houses rather than roofed ones was something other than a lazy or blind inclination to follow inn-yard precedent. Easy and adequate lighting and general publicity ${ }^{46}$ in stage presentation were no doubt weighty considerations; but of prime importance was the necessity of meeting the growing complaint that playing houses were "somewhat to close for infection", the "state of pestilence" where plague-inflicted persons were accustomed to be "pestered together in Small romes, specially in this tyme of Sommer'. This objection, as we have already seen, actors had attempted to meet by presenting their plays in courts and innyards; to meet the same objection Burbage and his followers erected "overt \& open places" for their performances. And under the circumstances there seems to be no special reason for believing that the idea of a roofless structure was suggested by the inn-yards rather than by the "game houses", banqueting houses or bear gardens of the period. At least actors were not following inn-yard precedent blindly.

It is often said that the old inn-yard principle of the removable stage was adopted in the public theatres because of the desire to use them for games of activity as well as for plays. I am not aware, however, of any evidence for believing the stage was a re-

\footnotetext{
4a The objection to plays in private houses is well brought out in Bishop Babington's discussion on the Ten Commandments (1588): "If they [plays] be dangerous on the day time, more daungerous on the night certainely: if on a stage, \& in open courtes, much more in chambers and private houses. For there are manie roumes beside that where the play is, \& peradventure the strangenes of the place \& lacke of light to guide them, causeth errour in their way, more than good Christians should in their houses suffer." (Forewords to Pt. I of Stubbe's Anctomy of Abuses, p. 83) Babington may have had in mind only private theatricals at the houses of the nobility, but it is entirely probable that he was also referring to performances inside inns or private houses used frequently for plays. In this connection should be compared the phraseology of the various decrees eited above and the words of Grindal in 1563, that it would be a good thing if players could be banished permanently from London as well as "the owners of the houses where they play their lewd interludes". (Remains, Parker Soc., p. 269).
} 
movable one at the Theatre, Curtain, Rose, Swan, Globe or Fortune. The Swan picture, which certainly seems to represent a fixed stage, cannot be used as evidence. Nor are the Messalina and Roxana pictures, which imply a similar kind of stage, of much value in this connection, since they are late and both may represent conditions at private houses. The "heavens" and pillars resting upon the stage at the Fortune, which was modeled after the Globe, certainly argue that these theatres had fixed stages. The Rose likewise had "heavens"; and there is nothing against believing that the pillars supporting this structure rested upon the stage. As we shall see later in connection with the Hope, a special arrangement was necessary when a theatre had both "heavens" and a removable platform.

Again it is difficult to comprehend how various scenes called for in early plays could have been presented at all acceptably on a removable stage. Surely for the successful manipulation of aseending and descending ghosts and devils, and for the adequate execution of scenes in the "cellerage", more depth was necessary than would have been possible beneath a mere platform which could be removed whenever the "yard" was to be used for bear baiting. "Hell", the regular name for the cellerage, must have been a sort of excavation boxed in and concealed from the audience by the three sides of a permanent stage. "Hell" and "cellerage" are good terms for such an excavated space.

Games of activity were, to be sure, probably practiced at all the theatres mentioned above, but they seem to have been confined to such things as tumbling, wrestling and fencing. For such sports an elevated platform is certainly preferable to the ground itself in the midst of spectators. In the case of bear and bull baiting the rererse is true; hence the question arises as to whether such sports were regularly held in the earlier theatres.

Scholars have generally assumed that bulls and bears were commonly baited at the early theatres as well as at the places about the city prepared especially for such entertainments. Rendle, for example, seems to say that such sports were common at the Curtain and Theatre, especially on Sundays $;^{47}$ and Professor C. W. Wallace England.

47 Appendix I, p. xvi to Pt. II of Furnivall's edition of Harrison's Description of 
asserts that bear-baiting was held at the Swan. ${ }^{48}$ They have failed, however, to give evidence for their assertions. Real evidence, I believe, for such an opinion cannot be easily found.

To be sure, Rye ${ }^{49}$ condenses a passage from a guide-book by Zingerling (cir. 1610) as follows: "The theatres (Theatra Comoedorum) in which bears and bulls fight with dogs; also cock-fighting.' But can Zingerling's words be trusted? Has he confused theatres and bear-gardens?

Cases of the word "theatre" loosely used are not diffieult to find. Hentzner, for example, who traveled in England in 1598, states pretty clearly that bull baiting was not held in the regular theatres. "Without the city", he says, "are some theatres, where English actors represent almost every day tragedies and comedies to very numerous audiences". And he is very careful to distinguish theatres and bear gardens as to their functions. "There is still another place", he continues, "built in the form of a theatre, which serves for the baiting of bulls and bears'. Yet a few lines further on, since he-like Zingerling-was not acquainted with the expression "bear garden", he fails to distinguish terms in the generalization: "In these theatres, fruits . . . . . are carried about to be sold, as well as ale and wine."'

Again, if the early playhouses were used frequently for the baiting of bulls and bears, it is rather surprising that the English themselves do not refer specifically to the fact, but on the other hand imply more than once that the playhouses were constructed primarily for plays instead of being a sort of hybrid between theatre and amphitheatre. If the baiting of animals were frequent at the Theatre and Curtain, especially should we expect to find the custom referred to in the various legal documents of the period. But what do we actually find? The order of November 1,1597 , for the destruction of these two houses, to give a single illustration, after referring specifically to plays, advises that "those playhouses that are erected and built only for suche purposes shalbe plucked downe, namelie the Curtayne and the Theatre nere to Shorditch, or any other within that county.", 50

On the other hand, when the Elizabethans constructed the Hope,

${ }^{48}$ Eng. Stud., 43 , p. 363 note 2.

${ }^{2}$ Eng. As Seen by Foreigners, p. 133.

${ }^{\infty}$ Quoted by Gildersleeve, Gov. Regulations, p. 187. 
which was to serve both for plays and the baiting of animals, it is entirely natural that this unique structure should be considered an innovation worthy of special description. And in no uncertain language Howe in his continuation of Stowe describes it as "a playhouse for stage-playes on Mondayes, Wednesdayes, Fridayes, and Saterdayes; and for the Baiting of the Beares on Tuesdayes and Thursdayes, the stage being made to take up and downe when they please." ${ }^{51}$ And that bear baiting was not practiced at other public playhouses in existence at the time of writing is apparently shown by the same writer, who states that whereas various theatres not mentioned (i. e., the Curtain, Rose, Swan, Globe, Fortune) "were erected only for common playhouses", the "new-built bear garden" was "built as well for plays and fencers' prizes as bull baiting." " 52

The removable stage, then, explains why bear and bull baiting was possible at the Hope. And it was an innovation in stage structure considered worthy of specific mention by Howe. Naturally, too, since the stage at the Hope was to be a removable one, pillars could not rest upon it as they had rested upon the fixed stage at the Swan.

It is usually said that the arrangement of galleries in the early London theatres had its source in the arrangement of galleries around the imn-yards in which the actors were accustomed to perform. Here again we are at least on uncertain ground. We have already seen that actors did not always seem inclined to take advantage of this peculiar inn-yard arrangement. Then, too, in an attempt to account for the galleries in theatres, the probability of other influences must be taken into consideration, especially the repeated preparation of large halls with scaffolds to accommodate the spectators at private performances and the nature of the numerous banqueting-houses and "places of pleasure" erected during the century.

In the first place it should be pointed out that scaffolds for spectators were constructed in halls or palaces long before we have any record of performances at inns. ${ }^{53}$ The following description, for

* Quoted by Ordish, Early London Theatres, p. 240.

${ }^{82} \mathrm{Cf}$. Forewords to Part II of Furnivall's ed. of Harrison's Desc. of Eng., p. 49.

* The first reference to plays at inns that has been noted is that of 1557 (Chambers, Med. Stage, II, 190, note 1; Maas, Eng. Theatertruppen, p. 53). Brooke's assertion 
example, dates from the time of Henry VII: "And this yere was a Roiall feste kept at Westmynster by the kyng, on the Twelvith day, where dyned the Mayr and his brethir, and at nyght was a disgysyng of xii ladyes and xii gentilmen. And all the greate hall was hanged wt Arras, and staged Round abowte wt Tymber, that the people myght easely behold", ${ }^{54}$ In the second year of Henry VIII's reign, Whitehall "was hanged rychly, the Hall was scafolded and rayled on all parts", on the occasion of a play by the Gentlemen of the Chapel, elaborate dances, and a movable pageant. ${ }^{55}$

Among later references to scaffolded halls the passage regarding entertainments at the Temple in 1562 is of interest: "It is proper to the Butler's office, to give warning to every House of Court, of this banquet; to the end that they, and the Innes of Chancery, be invited thereto, to see a play and mask. The hall is to be furnished with skaffolds to sit on, for ladies to behold sports, on each side. Which ended, the ladyes are to be brought into the Library, unto the banquet there." 56

When Edward's Palamon and Arcyte was presented at Oxford in 1566, Bereblock wrote: "Along all the walls balconies and scaffoldings were constructed; these had many tiers of better seats, from which noble men and women might look on, and the people could get a view of the plays from round about." ${ }_{57}$ Much later were the erecting of scaffolds at Gray's Inn in 1594 (Gesta Grayorum, Nichols, Eliz., ed. 1788, II, 17), those in St. Mary's and Christ Church in 1605 when James I visited Cambridge, ${ }^{58}$ and the scaffolds "on all partes filled with beholders" when Lord Knowles entertained Queen Anne at his manor in $1613 .^{59}$

(Tudor Drama, p. 64) that Mankind was acted in an inn-yard is merely conjectural. It is not at all certain that it was acted at an inn. The taking of a collection with the "goode man of this house" as the first victim is inconclusire. The "goode man" need not be an innkeeper rather than the owner of a manor.

4 Chronicles of London, ed. Kingsford, p. 200.

${ }^{55}$ Hall, Chronicle, p. 518.

${ }^{6}$ Nichols, Prog. of Eliz., ed. 1788, I, p. 23.

67 Trans. of Durand, Pub. Mod. Lang. As8'n., XIII, 505. Durand has suggested the probable influence of such structures on London theaters. I have added little to his earlier discussion.

68 Leland, Collections, II, 646.

60 Virian'a edition of Campion, p. 84. 
In connection with the tiers of seats in palaces and theatres, another sixteenth century institution should be considered-the banqueting-houses and places of pleasure common throughout the period. The "banquetynge hows" or "theatre" erected by Henry VIII at Calais ${ }^{60}$ was made "with xvj. principals made of greate mastes, betwixt every maste xiiij. fote, and all the oute syds closed with borde and canvas ovar it, and with in rownde abowt by the syds were made thre loftes one above anothar for men and women for to stond upon, and they that stode behynd myght see over the hedes that stode before, it was made so highe behynd and low before." ${ }^{61}$ The teinporary structure erected in 1519 in the courtyard of the Bastille for the entertainment of English ambassadors had "three tiers of balconies for the spectators." 62 Along the sides of the house erected by Henry VIII "to be furnished for disgusing and meskelying of lords and ladies" were, according to Spinelli, ${ }^{63}$ "three tiers of seats, each of which had a beam placed lengthwise, for the spectators to lean on, nor did one tier interfere with the other." The house, says Hall, ${ }^{64}$ "was raised with stages $\mathrm{v}$ degrees on every syde, \& rayled \& countreraled borne by pillars of Azure." The banqueting-house erected at Horsley in 1559 had at least one balcony, ${ }^{65}$ and the "sides" of the one erected at Westminster in 1581, says Holinshed, ${ }^{66}$ "was made with ten heights of degrees for people to stand upon."

In view of such conditions, one is inclined to accept Durand's remark ${ }^{67}$ that it is "entirely eredible that the notion of using the innyards for plays was derived from the previous experience of the actors in the great halls," and, one may add, from their knowledge of such "places of pleasure" as have been described. Nor

${ }^{80}$ Chronicle of Calais, Camden Soc., p. 29.

${ }^{61}$ Another account states that "around the walls below the ceiling are three tiers of balconies or stages, eight or nine feet deep, the parapet in front being of the height of a man's waist, and the tiers raised 10 feet one above the other, with sloping floors, so that the last look over the first, and behold conveniently what is passing on the ground floor" (Cal. State Papers, Venetian, 1520-6, p. 32).

${ }^{62}$ Cal. State Papers, Venetian, 1509-19, pp. 485-6.

es Ibid., 1527-33, p. 59.

64 Chronicle, p. 723.

${ }^{85}$ Doc. of Revels, ed. Feuillerat, p. 106.

${ }^{68}$ Chronicle, IV, 434. For the later structures of this sort see Reyher's account in his Les Ifasques Anglais.

${ }^{67}$ Pub. Mod. Lang. Ass'n., XIII, 526. 
is it improbable that when these actors undertook to build permanent houses, they went to such structures for suggestions rather than to the galleries of inns.

Durand (p. 527) has conjectured, indeed, that the oval or octagonal form of the galleries in the permanent theatres may have been suggested by the arrangement of the scaffolding in the great halls where the problem of making a theatre of a rectangular space would have naturally led to a cutting off of corners. So far as I know, there is no actual evidence that this was ever done at court performances, though at least one of the banqueting-houses of Henry VIII, the large one erected at Calais in 1520, is spoken of in one account ${ }^{68}$ as having "16 fronts," while in another ${ }^{69}$ is it called a "rotunda." The circular form of the early theatres, however, need not trouble us. As Child ${ }^{70}$ remarks in discussing the various sources that have been suggested for such a form-Roman amphitheatres, Cornish "rounds," circular stage settings of mystery and morality plays, bear and bull rings-the circle is the formation into which spectators naturally gather when they desire to witness something from various sides.

But even granting that Child ${ }^{71}$ is right in saying that "the innyard was, doubtless, responsible for the galleries" at the early playhouses, then is it not probable that suggestions for improvement were received through an acquaintance with a more fitting arrangement constructed in the halls and pleasure houses of the time? The point, though trivial, may be illustrated. The spaces, we are told, in the galleries which adjoined the rooms of the inn could be treated as the equivalent of our modern boxes during inn-yard performances. "Indeed," writes Professor Baker,"2 "the Elizabethan word 'room' for a theatre box held a memory of these spaces next the rooms of the old inns." The word "room" however, is a pretty general term; and it is not the only word used in Elizabethan times for the boxes in the theatres. It is perhaps worth while to remark, too, that these spaces next the rooms of inns were not so similar to theatre boxes or "stalls" as were the partitions,

${ }^{68}$ Cal. State Papers, Venetian, 1520-6, p. 32.

ov Ibid., p. 42.

${ }^{70}$ Camb. Hist. Eng. Lit., VI, p. 283.

1 Camb. Hist. Eng. Lit., VI, p. 284.

${ }^{72}$ Development of Shakespeare, p. 68. 
sections, or compartments, for instance, constructed in the banqueting-houses and seaffolded halls, ${ }^{i 3}$ where spectators were arranged according to rank or nationality. It is possible, too, that these sections arranged for spectators were called "rooms" (i. e., places) at an early date. An old writer, for example, describing the elaborately arranged hall at Westminster on the occasion of Prince Arthur's marriage in 1501, remarks: "And in this foresaid place when the King and the Queen had taken their noble seates under their Clothes of estate and euery other nobles were ordered in their Roomes worshipful and Convenient then began and Entcred this most goodly and pleasant disgusing, ${ }^{74}$ " etc.

The various things discussed above are by no means advanced, let me urge, as proof that the early theatre did not spring from an inn-yard original. They are given to show that there is no conclusive evidence in support of the idea that the yard rather than something else is was the structural original of the London playhouse, and that in all probability no such thing as a blind following of inn-yard conditions is to be traced in their architecture. Hostile to any such idea is the very fact that Burbage and his fellows constructed octagonal or circular frames instead of square or rectangular ones, that they built boxes suitable for gentlemen to sit in, that they erected a "heavens" and "cupola," and that they added other features at most but vaguely suggested by the so-called structural originals of their houses. And obvious as such things may have been, they at least argue that our early theatre-builders

${ }^{73}$ It is difficult to say just how general these compartments were. They were common in the later masqueing-houses (Cf. Whitelocke, Memorials, p. 19; Reyher, Les Masques Anglais, pp. 346-7). The banqueting-house erected at Whitehall in 1572 was possibly provided with them. Cf. the entry, "\& Compartementes, with pendentes \& armes paynted \& gilded for the purpose" (Doc. of Revels, p. 163). The passage following from a letter of the Spanish Ambassador in Jan., 1565, implies that such arrangements were common. After stating that he and the Queen watched the tournament given by Leicester for some time through a window of the gallery, he continues, "Cecil and the Chamber. lain put me in the gallery from which the Queen generally sees the feasts. There were three or four compartments divided by cloths, and they took me into one adjoining that of the Queen, and adorned in the same way as hers". The French Ambassador apparently occupied another compartment. (Cal. State Papers, Spanish, 1558-67, p. 403). Cf. also, Cul. State Papers, Tenetian, 1527-33, p. 59. On loges at religious plays on the Continent, see Cohen, La Mise en Scène, pp. 244-5.

${ }^{4}$ Reyher, Les Masques Anglais, 561; Collier, Hist. Dram. Lit., I, pp. 58-9, note. Leland, Collectanea, T, p. 359, reads "Places", which is all that the word "Roomes" means.

"It is impossible to say whether the Elizabethan theatres inherited anything from the "game houses", etc., such as the one erected in Yarmouth in 1538, which are occasionally heard of at an early date (Chambers, Ifed. Stage. II, 188.91, 244). 
were willing to accept suggestions from any sources that were readily accessible. With this fact in mind, let us approach the construction of the stage itself.

Here, again, the inn-yard has been pointed to as a source; and Professor Baker ${ }^{76}$ has drawn a picture showing how the gallery of the inn was used as a balcony beneath which was suspended a curtain at the rear of a projecting stage. The actor, he says, ${ }^{77}$ after suspending this curtain "used a room or rooms across the passage behind the eurtain for a dressing or 'tiring-room.', In this primitive construction he sees the original of the Elizabethan stage.

So far as I am aware, however, there is no evidence for such an arrangement before or after 1576. There is no reason for believing that whenever an inn-yard was used for a dramatic performance the scaffold or stage was erected at one end of the court rather than near the center. On the other hand, I do not know why Mr. Appleton Morgan ${ }^{78}$ asserted that for years after the permanent theatres were built, the stages in inn-yards were unattached to any side of the yard, as had been the case when early moralities were performed, unless he had in mind the earlier statement of Malone or the desire of actors performing in large yards to get closer to the spectators in the galleries.

Even granting, however, that the arrangement shown by Professor Baker was the original of the Elizabethan stage, then the origin of the frontal doors, their peculiar nature and significance are left entirely unexplained. W. J. Lawrence, ${ }^{79}$ who has recently advocated the inn-yard theory, recognizes this fact, and consequently affirms that when the first theatres were built, various improvements were suggested by the inconveniences of the earlier system of presentation. "To some extent", he writes, "the aspect of the tiring house recalled the background of the older stage in the innyards, but it would appear that at least one important hint had been taken from the screen of the banquetting halls in the palaces, universities and inns of court, halls in which the players had occasionally given performances. From this source came the principle

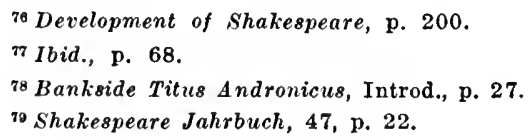


of the two frontal doors, forming the normal (but not complete) method of entrance and exit."

Lawrence may be right in his conjecture, but I do not believe that his explanation is the correct one. Nor do I think that the general structure of the Elizabethan stage was borrowed from Holland, as Creizenach ${ }^{80}$ suggests. An origin nearer home can be found. For reasons to be given below, I would derive the public stage in its essential elements from the English court; or perhaps I should say, it was suggested by the court methods of stage presentation.

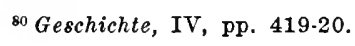




\section{THE STAGES AT COURT AND THE EARLY THEATRES}

It is a well known fact that from about the middle of the century to 1576 , or later, the majority of plays performed at court were presented by the Children Companies whose masters were university men or men with the equivalent of a university training. ${ }^{1}$ Under such circumstances it would not be surprising to find that these plays in their method of staging were affected more or less by the methods employed in the schools and universities of the time, that the authors, writing for a "learned" court where Rome was in fashion, and acquainted with the manner of presenting the comedies of Plautus ${ }^{2}$ and Terence, should look to the stage called for by the plays of Plautus and Terence for models in presentation. This they did; and many of the earlier dramas at court written by such men were undoubtedly staged in the strictly classic manner as then understood.

These strictly classic plays observed the unity of place, all of the action taking place before a single house, ${ }^{3}$ as in Jack Juggler or Ralph Roister Doister, in a street or "place" between two houses, ${ }^{4}$ as in Gascoigne's Supposes or in Gammer Gurton, or some-

1 Doc. of Revels, ed. Feuillerat, passim; Maas, Eng. Theatertruppen, pp. 151-153; MLod. Lang. Reveiw, II, pp. 2-6. For the Children of the Chapel and the training of their masters, see Manly in Camb. Hist. Eng. Lit., VI, 322, Stopes, William Hunnis, pp. $11,25,147$.

2 On Plautus and Terence in schools and universities, and Latin Comedy in England, see Wallace, Birth of Hercules, Introd., Miss Lee's ed. of Narcissus, Introd., pp. xiiixiv, Watson, Eng. Grammar Schools, pp. 318-24, Retrospective Review, XII, 1 ff., Canb. Hist. Eng. Lit., V, pp. 114-16, Ibid., Vol. VI, chap. on university plays, Schelling, Eliz. Drama, I, $81 \mathrm{ff}$., Bond, Plays from the Italian.

3 Classic staging is hardly to be traced in such productions as New Custom (pr. 1573), Youth, (1550?), Wager's Longer Thou Livest (1570?), yet when such plays where the action takes place near an ale-house or tavern were presented at court, there is always the possibility that structures representing such places were actually on the stage.

- Perhaps Calisto and Melibea and Apius and Virginia should be mentioned here. The date of the former is unknown. If it was acted at court, then perhaps a house for Calisto and one for Melibea were erected on the stage. Fleay (Biog. Chron., II, 290) identifies it with the Comodie of Bewtie and Huswyfery acted at Windsor in 1582. This play calls for "one battlement of canvas", which does not seem to fit Calisto and Melibea. In Apius and Virginin, acted by Children of the Chapel (Manly, Camb. Hist. Eng. Lit., VI, 320, says it was written not later than 1551), perhaps the palace of Apius and the house of Virginius were on the stage. Even more vague are the two "frames" (houses?) which were apparently used in the historye of Mutius Sceuola acted at Windsor in 1576 (Doc. of Revels, p. 266) and the two "frames" apparently employed in some play in 1578.9 (ibid., p. 299). 
times before even three ${ }^{5}$ or four ${ }^{6}$ houses, provided they were supposed to be in close proximity to one another. It is to such houses that the Revels Accounts refer most frequently when they mention " "apte houses of paynted canvas," "Stratoes howse," "Orestioes howse" and the like, rather than to such houses as were employed in mystery plays; that is, to painted canvas stretched on frames representing houses that could be entered by a door, rather than to such structures as are seen, for example, in the picture of the Valenciennes stage; in short, the houses (exteriors) of the Roman stage rather than the maisons (interiors) of the mystery stage.

Perhaps under the influence of sources, the English romantic instinct, or the method of presenting mystery plays ${ }^{7}$ and longer

${ }^{5} \mathrm{Cf}$. Hymenaeus, perhaps acted at Cambridge in March 1578-9 (ed. of Smith, Introd. p. $\mathrm{xv}$ ). In Jocasta the palace was probably at the rear of the stage with a labeled gate-way on each side of it. A sacrificial altar was also on the stage.

${ }^{6}$ Bugbears calls for either three or four exteriors. Fraunce's Tictoria has four houses and a temple. "A Comodie or Morrall devised on A Game of Cardes" acted at court on St. Stephen's Night, 1582, used "iiii or pavilions" (Doc. of Revels, p. 349). It is hard to say how many houses were called for in The Glass of Government. Cf. stage direction at the end of the first act, "They depart to their houses".

7 The influence of the staging of mystery plass must not be orer-emphasized in court plays. W. J. Lawrence (Shakespeare Jahrbuch XLV, p. 157) writes that "With the transference of the multiple setting [of mystery plass] to the indoor court plar came certain vital modifications of its principles. Questions of space demanded a reduction in the number of mansions employed and a more compact system of grouping. The maximum was now fixed at five, and the mansions were generally arranged in sets of three or five, according to the scenic exigencies". This is essentially true, but it should be noted that the rast number of court plays before 1576 or even before 1600 seem to demand only one, two, or three maisons or differently propertied localities. The very few that seem to call for four or five are decidedly classic. I should prefer, therefore, to say that the multiple setting of the mystery plays was not transferred to the court stage, but that it served to modify the "classic" stage. Says Vitrurius speaking of the proper setting for comedy: "Aedificiorum privatorum et moenianorum habent speciem, pro[sp]ectusque fenestris, dispositos imitatione communium aedificiorum". (Ed. Choisy, I, 245).

It is entirely possible that in some cases the workers at court were not employing the medieval method of staging so much as they were attempting to carry out the instructions of Vitrurius as to the proper background for the three types of drama-trageds, comedy, satyr-or the similar instructions of Sebastiano Serlio whose work appeared at Paris in 1545 and at Venice in 1584 (Cf. Bapst. Essai. 255). Serlio was apparently popular in Elizabethan times (Notes and Queries, Fifth Series, V, 381-2). Compare in this connection the extracts from Robt. Peake's 1611 translation of Serlio (ibid.) with the numerous cities of canvas, etc., in the Revels Accounts and the rural settings called for in various court plass. In Spain the instructions of Titruvius and Serlio seem to be echoed in the comment (cir. 1595) of Alonso Lopez Pinciano: "in accordance with the difference in time, besides the costumes of the persons in the action, there is required a corresponding decoration for the theatre itself, besides the necessary machinery, which ought to be in conformity with the poem: if it be pastoral, there should be woods; if the action take place in a cits, there should be houses; and so in accordance with the other differences, the theatre should have its various decoratious" (Rennert, spanish stage, p. 82 note). 
moralities, it is quite natural that this "classic stage" should be expanded, so to speak. The general plan of the setting would be kept, but instead of liaving two houses separated by a few feet, they would be represented as separated by considerable distance. And we find this thing being done in plays decidedly classic. In The Glass of Government and Jocasta the action, in accordance with good Renaissance standards, is at most confined to the walls of a single eity; in Thersites the "place" of the Mater and Mulciber's shop are surely supposed to be more than a few feet apart; and in The Misfortunes of Arthur, while the house of Modred and the cloister may be near each other, the "house prepared for Arthur" was certainly supposed to be far removed from them. Gorboduc is probably a similar example.

We do not find on the English court stage one side of the stage being reserved for entrances from the city or market-place, the other side for entrances from the country. We do find, however, a similar sort of thing, a city being erected on one side of the stage, a "country" on the other side. And this seems to have been a very popular method of presenting court plays; that is, on one side of the stage was constructed a "house" of painted canvas, a castle or a city, while on the other side was constructed another city or castle or country or anything else necessary.

A good example of a play staged in this manner is the Damon and Pithias, acted at court on Christmas Day, 1564. "Edwardes tragedy" is mentioned in the Revels Accounts (p. 116) in connection with "officers and Tayllours payntars workinge divers Cities and Townes . . . and howsses and other devisses." 8 In presenting this particular play, the castle of Dionysius was constructed on one side of the stage, Syracuse on the other. It is to these properties that the Prologue presumably points ${ }^{9}$ when he says:

"Lo, here in Syracuse th' ancient town, which once the Romans won,

Here Dionysius palace, within whose court this thing most strange was done."

\footnotetext{
"For evidence that "Edwardes tragedy" and Damon and Pithias are the same play, see Durand in Mod. Lang. Notes, 23, p. 131; Journal of Germ. Phil., IV, pp. 348-55.

${ }^{9} \mathrm{Cf}$. a similar device in Beza's Abraham Sacrifant, translated by Golding in 1577 (ed. of Wallace, p. 95). This explanation of the mise en scène was a common function of the prologue in early French religious plays. Cf. Stuart, Stage Decoration in France, pp. 118, 166, 172, 179.80; G. Cohen, La Jise en Scène dans le Théatre Religieux Français, pp. 75-77.
} 
And the characters in Edward's tragedy are often rather careful to tell us that they are either going to or have just come from the city or the court. When they do not tell us so much, it is obvious that they have either come from or are going to this same city or court. Cambises was no doubt staged in much the same manner. If the play was acted at court, and we can be virtually certain that it was, ${ }^{10}$ then we can be pretty certain that on one side of the stage was the palace of Cambises, on the other side a city or inn before which the comic scenes (Il. 125-292, 732-824) are supposed to take place. Between them was the "pleasant green" which, it may be noted, is not much out of place before the castle. There are no interior scenes. A banquet is served, but like many Elizabethan banquets, it was served out-doors. In Ingeland's Disobedient Child, probably acted at court ${ }^{11}$ on March 6, 1560-1, an inn apparently stands at one side of the stage and a city (i. e., London, about forty miles away), or the father's house in London, on the other; but as the play presumably has a place or property to which the unfortunate husband can take the clothes as if to the river and wash them without leaving the stage, it should perhaps be discussed with the plays mentioned later.

If it be objected that a "city" would hardly be raised at the side of the stage, then let us turn to the ten or twelve plays mentioned in the Revels Accounts calling for a "battlement" and a "city." It would be as easy to build a city at the side as to erect a battlement there; and surely both were not placed at centre back. In the Portio and Demorantes, acted at court in 1578-9, a city and a town are called for (Doc., 321); a play acted at court by the Lord Chamberlain's Servants in 1579 (ibid., 320), and one presented on Twelfth Night, 1580, both call for a city and a country house (ibid., 321). In 1568 Benger wrote of a "Scotlande and a gret castell one thother side." Unless we assume a shifting of painted scenery-a device first practiced at court by Inigo Jones-we must believe that the Elizabethans were rather fond of placing such things as cities at the side of their stage. ${ }^{12}$

${ }^{10}$ Fleay, Hist. of Stage, p. 64.

11 Fleay, Biog. Chron., I, 307.

12 There is, it seems to me, no especial reason for supposing that the entries in the Revels Accounts calling for the stage settings of particular plays are radically incomplete. W. J. Lawrence writes that "the entries in the Revels Accounts dealing with the pro- 
Alongside these plays with countries, houses or cities on each side of the stage, we should expect dramas in which the "middle space between", instead of being merely covered with arras or painted cloths, as it no doubt was in many early plays, should be utilized for such places as could not well be located at the side. At centre back was perhaps located the hole into which the worthy doctor stuck his head in Gammer Gurton, and the den from which Tediousnes issued in The Marriage of Wit and Science. Here, too,

vision of scenic appurtenances for specific plays afford little clue to the actual staging". "These items merely represented", he continues, "new material. Many mansions and other properties in stock were used again and again" (Sh. Jahrbuch, 29, p. 157). Says Feuillerat: "Et si la liste des décors que nous connaissons n'est pas aussi longue que celles des accessoires, c'est tout simplement parce que les comptes ne mentionnent que le matériel construit dans l'anneé et renant s'ajouter au matériel déjà en service" ( $L e$ Bureau, p. 66).

I cannot help feeling a certain impertinence in questioning the statements of such recognized authorities, but I believe that they are not entirely correct in their assertions. To be sure the accounts frequently speak of a battlement or city as "newe em. ployed", but this does not necessarily mean that old scenery was regularly re-used. Frames were sometimes re-employed (Doc., 121), but surely not the canvas stretched over them. And we can be pretty sure that when even frames and smaller properties made their reappearance, they were altered beyond recognition (Doc., pp. 117, 120, 153, "Platt" facing page 16). In 1572 Thos. Gylles wrote that a costume "never com before her heyghnes twysse In on forme" (Doc. 409). Surely this was also true of such cheap and transient materials as frames and painted canvas.

I would not contend that the store-room during the time of Elizabeth was as full of once-used properties as it perhaps was in the time of Henry VIII or the period following Elizabeth's reign, when, according to Shirley, "all the properties [of clouds in masques] have been paid forty times over, and are in the court stock"; and when Jonson expostulated again Inigo Jones's "Thrice conceived, thrice paid for imagery". There is, bowever, considerable reason for supposing, it seems to me, that at least during the first twenty-five or thirty years of her reign a battlement, eastle, town or city never made more than one appearance before Elizabeth. In the first place it is important to note that none of the plays which we know were actually presented at court during those years calls for a larger number of cities, towns, etc., than are regularly mentioned in the documents in connection with the various plays. It is important to note, too, that plays presented within a few days of one another and calling for identically the same kind of scenery nevertheless seem to have had special equipments. TQ illustrate. In 1564 we have the entry, with "Edwardes tragedy" in the margin, "canvas to cover divers tawnes and howsses" (Doc., 116). In the same year under "Sir Percyvall hartes sonnes" play we have "paynttars workinge uppon divers Cities and Townes", and for the masque by the Gentlemen of Gray's Inn, "payntars workinge uppon the Townes" (ibid., 117). In the accounts for 1579-1579-80 numerous cities are mentioned together with two battlements and two country houses; and in the list of plays of 1580-81 six cities and four battlements are called for. It certainly seems that the very things that we expect to have been re-used-towns, battlements, cities-served only once, and that a special background was "new made" for each play. The pieces of scenery were no doubt rich and elaborate but only a few separate pieces were employed. It is difficult to say how large the cities and battlements really were.

And finally, it is not at all likely that Elizabeth, a lover of variety and showy per. formances (Cf., e. g., Spanish State Papers, 1580-86, p. 93), would have tolerated the reappcarance of painted scenery. 
were placed the elaborate woods and gardens in various plays to be mentioned later, ${ }^{13}$ the prison in the play performed at court by Warwick's Servants in $\mathbf{1 5 7 8 - 9}$ (Doc., p. 327), and probably the "mounts" meutioned at various times in the Revels Accounts. The extremely frequent "battlements" referred to in the same documents seem usually to have been made of canvas. When they were practicable and capable of being stormed, as was the one in Horestes, or were provided with "rayles" made of "ffurre poles" (Doc., p. 327), they were in all probability located at the rear of the stage.

The Marriage of Wit and Science, probably the Witte and Will mentioned by Benger as having been presented at court between July 14, 1567, and March 3, 1567-8, is a good example of a drama of the group under discussion. On one side of the stage was located the house of Wit, on the other the house of Reason in which Science, his daughter, also dwelt. Between them, "as you come and go" from house to house, was the "deadly den" of Tediousness. There are no interior scenes. John Redford's Play of Wyt and Science aud other dramas to be discussed later were obviously

Other things should perhaps be mentioned in this connection. Revels property does not seem to have received the best of attention. It was allowed to remain on the floor and in rotten presses (Doc., pp. 186, 411,455-56,474); it was, as Giles tells us, rented to outsiders; it was lent to the universities (Malone Soc. Collections, I, 2, p. 213; ibid., I, 3, p. 248; Rainolds, Overthrow of Stage Plaies, pp. 25, 75; Mod. Lang. Review, Jan. 1911, p. 93 ); it was given as fees to actors and officers (Brewer, II, p. 1509; IV, 1553, etc.; Doc. of Revels, pp. 25, 27, 111; Losely Manuscripts, ed. Kempe, pp. 62, 83; Chambers, Tudor Revels, p. 20; Pub. Mod. Lang. Ass'n., XVII, 189); the practice of plundering seems to have lasted from the time of Henry to that of James I (Hall, Chronicle, 519; Brewer, II, p. 1495; Doc. of Revels, 23, 24, 202, 338, 435, 162; Brotanek, Eng. Maskenspiele, 113-114). The custom of giving property to masquers, which was extremely popular in Henry VIII's time, perhaps continued to a considerable degree dur. ing the reign of his daughter (Brewer, I, 718; II, 1493, 1498, 1502.4, 1550, 1510; Hall, 566, 724; Doc., 23, 24, 202; Reyher, Les Masques Anglais, 45, 421.2). These things imply extravagance and carelessness. And canvas and frames, we can be pretty sure, did not meet with much consideration after serving once, especially since they were not capable of being re-made or re-designed to the extent that costumes were.

${ }^{13}$ It is hard to say just how much decoration was bestowed upon the woods and gardens on the court stage. If we can judge from the elaborate pageants representing such places that were drawn into the hall during Henry VIII's reign, they must have been rather elaborate affairs. Cf. the "pageaunt of a great quantite" representing a forest and castle in the second year of his reign (Hall, Chronicle, 517), "the Golldyn Arber in the Archeyerd of Plesyer" of 1511 (Brewer, Letters and Papers, II, 1495-6), the "Gardyn de Esperans", of 1516 (ibid. p. 109, Hall, p. 586), etc. When at Oxford in 1566, Lady Amelia sang sweetly while "gathering her flowers prettily in a garden then represented", she probably performed before quite a gorgeous background (Nichols, Prog. of Eliz., ed. 1805, III, 112). 
staged in much the same manner. Indeed, one is even inclined to say that in Redford's play the house of Wyt was located on the right side (to the audience) of the stage, the house of Reason on the left. ${ }^{14}$

On such a stage an interior scene could only be suggested at most. And as a matter of fact, in the plays of this type there are no scenes that require an interior setting. On the other hand, the greatest care is taken to keep the action outside the houses, as in the plays just mentioned or the serving of the banquet in the open air before the King's palace in Cambises. To be sure, we sometimes have rather delicate scenes taking place in the open. Courtships, even engagements, occur in the streets. Kings, too, frequently discuss state matters, not in the council-chamber, but in the court or garden before the palace. Such scenes have sometimes caused scholars trouble. Creizenach, for instance, says of Gascoigne's Glass of Government: "Der Schauplatz schwebt ganz in der Luft: bald haben wir uns ein Zimmer, bald eine Strasse als Ort der Handlung zu denken. . . . Nach einer Schulscene Akt 1. Sc. 5 tritt Lamia mit ihrer Sippschaft auf und Eccho sagt (S. 23): 'I saw a frosty bearded Schoolmaster instructing of foure young men erewhyle as we came in.' Vielleicht hatte die Bühne einen Hintergrund, der durch einen Vorhang abgeschossen werden konnte." 15

It is somewhat surprising to hear a teacher lecturing in the street, but in all probability that is just what happens here. There

\footnotetext{
${ }^{24}$ Certain entries in the Revels Accounts, though necessarily very uncertain, should perhaps be mentioned here as showing how the central back portion of the court stage was possibly sometimes utilized. The plays of $1571.1571-2$ had in addition to "apt howses" made of painted canvas, "sundry properties incident, ffashioned, paynted, garnished and bestowed as the partyes them selves required \& needed" (Doc., p. 145); while the accounts for 1572-1572.3, after speaking of "sparres to make frames for the players howses", refer to "A tree of Holly for the Duttons playe", "other holly for the forest", "trees \& other things . . . . for A wildernesse", "Tymber for the forest" (ibid., pp. 175, 180). The accounts of 1573-1573-4 call for canvas painted for players' houses and also for "great hollow trees", "leaves of trees", "Ivy for the Wylde menne \& tharbour" (ibid., pp. 197, 200). On Nor. 25, 1574, a payment was made for "Oariage of iii Lodes of Tymber for the Rock (which Mr. Rosse made for my Lord of Leicesters menns playe) \& for other frames for players howses" (p. 244); and on Dec. 28, a similar payment is made for the carriage by water to court of "a paynted cloth and two frames for the Earle of Leicesters" (p. 266). The History of the Knight in the Burning Rock, 1578-9, possibly used two frames besides an elaborate rock (p. 310); the History of Love and ffortune, 1583, required a city and battlement of canvas, "a — canvas" ( $p .349)$, etc.

is Geschichte, III, 554 .
} 
is some doubt as to whether two houses or four were employed in presenting this particular play, but there is not doubt that the author took considerable pains to observe the unity of place and to keep the action outdoors. Professor Cunliffe ${ }^{16}$ wrote a short time ago regarding Gorboduc, that nearly all the dialogue is delivered in the council chamber of the King. There seems to be nothing in the text, however, to locate the dialogue definitely in the council chamber. Very similar dialogue occurs in The Misfortunes of Arthur, a play that in more than one way seems to have been influenced in its method of presentation by Gorboduc. In Hughes's drama we are told definitely in stage directions that a cloister was prepared for the queen to enter, a house for Modred, and another for Arthur. Characters come out of and enter these houses, but they do not carry on conversations inside them. In Gorboduc, I venture to say, the dialogue was carried on before the palaces of the King, Ferrex, and Porrex. Both plays kept the plan of the classic stage but increased, as it were, the distance between the houses; many places were "inartistically" suggested.

But whenever the need for actually presenting interior scenes instead of suggesting them was felt, the Elizabethans did not merely feel the need in silence. Nor did they invent an elikyklema as Wegener seems to think. ${ }^{17}$ They erected, probably at centre back, a frame or structure more closely resembling the houses of mystery plays and longer moralities, such frames as had perhaps been also used in such early indoor plays as Queen Hester and Johan Johan. ${ }^{18}$ Before this structure a curtain was no doubt often

${ }^{16}$ Camb. Hist. Eng. Lit., V, 74.

17 Bühneneinrichtung des Shakespeareschen Theaters, p. 58.

${ }^{18}$ Other early plays that seem to call for such a structure are Nice Wanton, Wager's Mary Magdalene, Mankind, Conflict of Conscience, though they are all doubtful. Johan Johan does not fit in with Albright's theory of staging; hence when Johan is sent for the priest he is made to leare the stage and seek the worthy at "a door at some other part of the room" (Shakesperian Stage, p. 33). This is unnecessary. The play was acted at court; and it was based on French farce in which exteriors and interiors were regularly presented simultaneously (Stuart, Stage Decoration in France, pp. $214 \mathrm{ft}$.; Aubertin, Hist. de la langue et de la litt. fr., I, 648, note, etc.) Regarding the staging of Mankind I am unwilling to commit myself. I will say, however, that Albright's diagnosis of it as "an open-air plas beside a tree" (p. 33) is as erroneous as Brandl's "eryke" and "deambulatory". He forgets that at certain points (cf. ll. 143, 153.4, 202) the action is presumably in a house, and that the "tree" beside which the play takes place is a gallows-tree which is brought on the stage by Mischief at 1.792 and held by Now-a-days while they prepare to hang Mankind. "Tree" in the sense of gallows or gibbett is good Elizabethan English. Cf. e. g., Sir Thomas Ifore, Sh. Soc. Pub., III, 35, Two Tragedies in One, ed. Bullen, IT, ix. 
suspended, as had been done in mystery plays, and as was the case with respect to the senate house used in A Story of Pompey acted in 1580-1 (Doc., p. 336), the cell in the Old Wives Tale, and Sapho's bed chamber in Lyly's Sapho and Phao. And in order to make these interior scenes convincing on this stage of simultaneous setting, the action that was supposed to take place inside a house did not sweep along before a city or the exterior of another house, but was actually confined to the structure representing the interior. ${ }^{19}$ The "bower" of Melissa in Misogonus is a case in point. Gismond of Salerne, presented before the Queen in 1576, seems conclusive. Tancred's palace occupies one side of the stage, Gismond's chamber the rear. The action of $\mathrm{V}, 2$ and 3 takes place in Gismond's chamber. Note in this connection the stage directions: "Renuchio delivereth the cup to Gismond in her chamber" $(\mathrm{V}, 2,1)$, "Tancred cometh out of the palace" (V, 3, 1), "Tancred entereth into Gismond's Chamber" (V, 3, 4), "Tancred cometh out of Gismond's chamber" $(\mathrm{V}, 4,1)$. The dialogue between the last two directions takes place inside the chamber where Gismond dies. No scenes are presented inside Tancred's palace.

In a word, there is not a symptom of alternation in any extant play written before 1576. All were written for the strictly classic stage, for a simple platform, or for what may be called, perhaps not inappropriately, the modified and expanded classic stage discussed above. And, as we shall see later, the same seems to be true of most of the plays acted at court before 1603 .

While such dramas were being acted on the stage or stages which I have tried to describe, there lived in England a person, who, judging from his subsequent career, did not wait to receive ideas and inspiration from Italy or Holland before he accomplished things. When the company containing this practical Burbage (the same Burbage who later on presumably fitted up the Blackfriars after court fashions) decided to build a permanent stage on which he and his companions could train for court performances-and of course make money-a stage on which they could act plays that

${ }^{10}$ On the more crowded French stage this was probably not always the case. Cf. the theory of Rigal, Theatre fransais avant la periode classique, p. 264. I do not mean, of course, to imply here that all interior scenes presented later in the public theatres were confined to the rear stage. In scenes, however, where the inner stage represented an interior and a door an exterior (see below) the indoor action was probably conflned to the rear stage. 
had been acted at court and such plays as would be acted at court; in fact, a stage on which any sort of play with which they were acquainted could be presented with equal ease and adequacy, surely it is not attributing too much ingenuity to this Elizabethan to suppose that he should take as his model, not the old improvised stage alone, but the regular arrangements of the stage at court, a stage on which he and his fellows had frequently acted, ${ }^{20}$ and with the working of which they had been further familiarized through rehearsals before the Master of the Revels. ${ }^{21}$ And should it be surprising that he remedied the limitations of a less adequate system? Many of the plays cited above could, of course, be acted on a stage erected in inn-yard, or guild-hall, but far more satisfactorily and convineingly on the court stage with its various possibilities.

When Burbage observed how all difficulties in stage presentation had been overeome at court, let us suppose that the observation put him to thinking. In his public theatre he could not well construct "howses" of painted canvas at the sides of his stage, a city or a "Scotlande," but he could do the next best thing-he could set in painted wooden walls two doors with windows above them, which could, and did, take the place of canvas houses; and by the use of sign-boards ${ }^{22}$ he could transform these sides of his stage into a "Thebes," or "Asia" or "Phrygia," while behind these same doors actors could dress as they had probably done within the "howses" at court. He could not conveniently build a "mount", or a battlement of canvas at the rear of his stage, but he could take the balcony of the court stage, so to speak,-or the gallery of the inn-yard, if one prefers-place it between his two doors and make it serve for a "mount," a rock or a battlement. He could not eco-

${ }^{20}$ Doc. of Revels, passim; Fleay, Biog. Chron., II, 289; E. K. Chambers, Mod. Lang. Review, II, 5.

${ }^{21}$ Heywood, Apology for Actors, p. 40, Feuillerat, Le Bureau des Menus Plaisurs, pp. 55-56, Doc. of Revels, pp. 176, 179, 238, 277, 297, 301, 325, etc.

${ }^{22}$ For the common practice of writing the names of cities over gateways, see Jusserand, Lit. Hist. Eng. People, III, 65. A play which employed a door to represent a city and which was probably staged very similarly to certain plays at the English court is the San Hermenegildo, acted in 1570 by the students of the College of San Hermengildo. In the presentation of this tragedy there was at the front of the stage "a large door of fine architecture, representing the city of Seville, on the frieze of which was a shield with the letters S. P. Q. H." Through this middle door entered only those who came from Seville, those coming from elsewhere entering at side doors (Rennert, Spanish Stage, 24). 
nomically construct prisons of canvas at centre back or curtained senate houses, but he could suspend before the recess beneath his upper stage a curtain such as he had seen used at court, or such as had hung before the "scene" of improvised stages prior to 1576 ; and this recess could be made to serve for a prison or senate house, a bower, an arbor or a den. He was not concerned with having maskers move from the "howses" prepared for them at the sides of a stage into the centre of a large hall, but he was concerned with affording acrobats sufficient room for their tumbling and fencers adequate space for their bouts. He erected a platform large enough for the purpose.

This stage so constructed was extremely flexible and elastic. It was really a multiple court stage, as it were, which in an instant could be fitted to all the possibilities of the court stage before 1576 . On it could be presented with equal ease and rapidity a simple performance with unpropertied and unlocated action as The Pedler's Prophecy and various earlier productions, ${ }^{23}$ a play like Tom Tyler or King Darius requiring a single interior setting, ${ }^{24}$ a classic play with one house as Ralph Roister, or with two as Gammer Gurton, a drama like Damon and Pithias demanding a city and a castle, a play like Gismond of Salerne or Misogonus

${ }^{23}$ Albright in his brief and somewhat careless discussion of "The Interludes and Shorter Moralities" classes as this type of play Respublica, Lusty Juventus, Impatient Poverty, Love, Mind, Will and Understanding, Magnificence, Four P's, Wealth and Health, Trial of Treasure, God's Pronises, New Custom, Albion Knight, Wit and Science, Dis. obedient Child. He might have added Bale's Johan the Baptist, and Three Laws, perhaps, and Heywood's Wit and Witless. Hyckescorner also really belongs here. The first five plass of Albright's list above contain nothing in the text, to be sure, that implies located or propertied action. The same is probably true of Four P's, Wealth and Health, and Wapul's Tide Tarrieth No Man. Trial of Treasure and New Custom are doubtful (See above). God's Promises probably represents heaven and earth simultaneously. Albion Knight is a mere fragment. Surely we are not justified in saying how it was staged any more than we are with respect to other fragments as Dux Mroraud, Love Feigned and Unfeigned, Temperance and Humility. Mlagnificence is a case of "idealized location" (cf. 1l. 957, 1966, 2263, and Ramsay's Introd., pp. xliv-vii). Wit and Science and Disobedient Child are almost certainly cases of simultaneous setting.

These plays of "unlocated and unpropertied action" are extremely uncertain; and Albright in his discussion of them lesves out of consideration the fact that many of them were written for court performance where from a very early date such things as painted houses were employed, and the fact that plays regularly followed a masque where the "scenery" of the masque may have been used as a background for the action of the play. Albright has also neglected, I may add, to consult Brandl's discussion of the staging of these early plays.

24 Other early plays, in which the action seems to be confined to a single interior are King Johan (9), Wether, All for Money, Four Elements (?), Pardoner and Friar, Like Will to Like (i). 
calling for the exterior of one liouse and the interior of another, a production like Horestes requiring a castle and a practicable battlement, plays ealling for "two Frames" (cities or houses) and a battlement, or a play like John Redford's Wyt and Science employing two houses, a den and perhaps a mount. And every feature of this very elastic stage, it should be noted again, had appeared with more or less frequency on the court stage before 1576.

Now after having constructed a stage with the possibilities of this one on which plays acted at court could be presented easily and adequately, and without a single change of setting, surely Burbage and his fellows did not take the trouble to get up special versions of court plays adapted to the public stage. Why assume that the same play was staged in one way at court and in an entirely different manner on the public stage, when the same production could have been staged in the same manner at court and in Burbage's theatre?

Let us cite specific examples to make this clear. Rare Triumphs of Love and Fortune (pub. 1589, as having been presented before Her Majesty) requires only Bomelio's cave, a practicable tree and the exterior of the palace of Phizanties. All the action takes place in a wood, before a cave, and before the palace. As presented at court, the palace was perhaps located at one side of the stage, the eave on the other, and the wood of painted canvas with a practicable tree or trees at the rear. When such a play was to be acted on the public stage where the cave could be represented by the inner stage--or a door-the tree located at one side of the stage-or before the rear stage ${ }^{25}$ - and the castle be represented by a stage door, there is no reason to suppose that a special method of staging was got up for the regular theatre. Mucedorus, printed in 1610 as it was acted before the King at Whitehall by his Highness's Servants usually acting at the Globe, calls for the castle of the King of Arragon, the palace of Valentia and a wood. There are no interior scenes. Orlando Furioso, published 1599 as it was "played before the Queenes Maiestie," calls for the exterior of the palace of Marcillus, the walls of Rodamont and a grove. Such

${ }^{25} \mathrm{I}$ do not say that trees were never placed on the rear stage. There is no reason, however, for supposing that such was ever done before 1603 . 
plays as Peele's Arraignment of Paris with its forest setting and bower of Diana, Lyly's Loves Metamorphosis with its temple of Cupid and the rock and tree of Ceres near a seashore, Midas with its temple of Apollo, palace of Midas and "reedy place," Campasbe with its palace of Alexander on one side of the stage, a city (?) on the other, and the shop of Appeles at the rear, Queen Dido with its walls of Troy, palace of Dido and wood on the Phrygian shore-all these could have been presented on the regular stage adequately and in the same manner as they were presented at court-with simultaneous setting. And the same is true of such court plays as Woman in the Moon, Endymion, Gallathea, Liberality and Prodigality, Maydes Metamorphosis, Phillips's Patient Grissell, Wars of Cyrus.

The stage devised by Burbage, then, and followed by later builders in general plan at least, was extremely elastic. But it had limitations. Two interior scenes, for example, or two forests and two castles, a prison (interior) and a den, or the exterior of four houses, or the exterior of three houses and the interior of another one could hardly be represented simultaneously. When therefore under the influence of sources or romanticism it was desirable to present more than three distinct localities which could not be represented simultaneously, it is not strange that playwrights and stage managers should use the two stage doors to represent the exteriors of two houses in one scene and two entirely different ones in another scene, or that they should employ two permanent houses (stage doors) and place between them a forest that could change its locality; that is, a setting which at one time, when located by the actor's lines, could represent a grove in Arabia, at another time could represent a wood or seashore in Phrygia. And this is just what we find in Common Conditions. In this particular play, "Phrygia" was written over one door while the other door probably represented the castle of Cardolus. Between them was the changing forest. And it should be noted that considerable care is taken here, as was no doubt the ease in other plays of this type, to avoid confusion or absurdity of entrance and exit. ${ }^{26}$ To illus-

\footnotetext{
${ }^{26}$ Note the Percy directions, and the advice of Dekker to the gull: "And first observe your doores of entrance, and your exit, not much unlike the plaiers at the The atres", etc. (Cited by Lawrence in this connection, Shakespeare Jahrbuch, (1909) p. 165). Of. also the coaching of actors in the Commedia dell' Arte to avoid absurd exits
} 
trate: Clarissa and her brother appear in an Arabian wood. We are told in a stage-direction that they are to enter, not ont of Phrygia or out of Cardolus's castle, but "ont of the wood." Other characters are told to enter further on "out of Phrygia." A somewhat similar forest is seen in Sir Clyomon and Sir Clamydes. In Mucedorus and such plays as The Maydes Metamorphosis the wood seting represents now one part of the forest, now another part of the same forest. As You Lite It has one scene apparently before Oliver's house and two scenes before the palace of Duke Frederick. There are no interior scenes. Between the two stage doors, that could represent the exteriors previously mentioned, was placed the Forest of Arden, which is much like the wood scenes above. The rood setting located at the side, or sides, of the stage in Greene's Alphonsus does not at all interfere with the few scenes in the "place behind the stage," is entirely appropriate as a background to the various battle scenes, and it serves equally well to represent the grove in which the exiled Fausta (III, 3) laments her fate and the "Thickest Shrubs" where Venus and the Muses meet in the prologue and where they no doubt re-assemble in the Epilogue. In Orlando Furioso the grove is presumably near the palace of Marcillus in certain scenes; in others, III, 2, for example, rather removed from it.

Similarly, when the "den" of Irksomeness and the "prison", into which Wit is dragged are called for in the same play, it would be an easy matter for the curtained space at the rear to represent the den in one act, the prison in another (Marriage of Wit and Wisdom, MIS. dated 1579). Again, when two entirely distinct and differently propertied interiors were to be presented in the same drama, we can rest assured that these Elizabethans did not overlook the possibilities of the curtain at the changeable "midst" between the doors. Is it against this floating middle region that Sir Philip is complaining when he says that we have Asia on one side of the stage, Africa on the other side, and "so many other underkingdoms that the player when he commeth in, must ever begin with telling where he is?" It would be an easy step to locate the

(Mantzius, Hist. of Theatrical Art, II, 215), and the reservation of particular entrances for particular characters on the Spanish court stage (Rennert, p. 24). There is no reason to believe that absurd entrances were more frequent on the Elizabethan stage than they were on the stages of Greece, Rome, or sixteenth century Italy. 
interior permanently, ${ }^{27}$ as for example the study in Friar Bacon, or the forest, and have the stage doors represent now a house in Asia, now a castle in Spain; or to let both forest and doors travel in Europe, provided each move was located by the lines of the actors, chorus, signboards, or general situation. Nor is this reusing of "scenery," so to speak, unknown elsewhere. A similar thing had probably been done in Attic Comedy; ${ }^{28}$ it was resorted to as a means of keeping down the number of maisons on the early French stage ${ }^{29}$ it was perhaps practiced occasionally at court at no very late period. ${ }^{30}$

When necessary, "alternation" is not to be wondered at, but it is not so often necessary-not even in chronicle plays and violently romantic dramas-as is sometimes supposed. Nor should it be surprising that such a practice developing under the necessity of presenting more naturally a large number of differently propertied scenes should continue to develop as a practice or principle as the playwrights, realizing the possibilities of the stage for which they wrote, became more and more extravagant in their demands for dissimilar locations and properties. Beds, thrones, chairs, trees, wells were never piled confusedly on the Elizabethan stage, as Albright apparently thinks that Reynolds believes. In sixteenth. century England where the performance of indoor mystery plays was only sporadic and where the regular actors had received their early training in the methods of the "scaffold hye" and the halfRoman, half-medieval methods practiced at court, of course nothing like such an elaborate setting as is seen in the Valenciennes picture was ever seen on the London stages. No one would contend that the setting of the Castle of Perseverance was straightened out, as it were, and placed in the theatres of Henslowe and Burbage. The Elizabethan playhouse, arising under circumstances vastly different from those which shaped the first theatre in France, never

2 It seems to have been a rather common practice to arrange the rear stage at the beginning of the play and allow it to remain undisturbed throughout the performance. Cf., for example, Lord Cromwell, Nobody and somebody.

${ }^{28} \mathrm{Haigh}$, Attic Theatre, 3rd ed., p. 198.

20 Stuart, Stage Decoration in France, pp. 21, 26, 27, 113, 184.

a Mother Bombie is a possible case. In The Old Wives Tale it is pretty certain that the curtained structure which served for Sacrapant's cell also represented the inn, and that the table and chairs which were placed in the former also served as properties in the latter. In late court plays a sort of alternation was apparently rather common. 
as a rule revealed even such complicated stage-settings as were common in the Hôtel de Bourgogne with its unbroken tradition in the methods of stationary mysteries and its rich inheritance from medievalism through the medium of the Confrères de la Passion. The peculiar nature of the Elizabethan stage made congestion unnecessary. The need for a large number of differently propertied locations led, as we have said, to alternation more or less regular; and a similar demand in elaborate private entertainments led Inigo Jones at a somewhat later time to employ a sort of periaktoi and still later to shift his scenes much in the modern manner.

When, however, alternation is not necessary, we have no right to assume it. When a sixteenth century stage could be set before the beginning of a play, as in the dramas referred to above, and the play in accordance with a well-established prineiple of staging be presented adequately and without disturbing the setting as originally arranged, we are certainly not justified in demanding a "shifting of the scenes." And even in plays where five, six or" ten different and definitely propertied locations are presented, dramas in which the properties on the rear stage must have been changed more than once in the course of the performance, we should not be surprised to find here and there in such plays the stage representing at the same time two entirely different places, as, for example, the exterior of one house and the interior of another, the exteriors of a house and a castle, or a forest and an interior; or in other words, cases of simultaneous setting within an act or scene. Such eases are, I believe, easy to find. Most of the so-called crudities, as Reynolds pointed out long ago, are probably examples of this very thing.

No one, I suppose, would deny that the two stage doors could be, and were, nsed in the same scene to represent the exteriors of two entirely different houses. It is not necessary to multiply examples of this. Arden of Feversham, III, 2, 4, and Knack To Know An Honest Man, scenes 8, 9, 10, 11, 12, 15, show it. Surely then it is not a radical step to find in other plays of the period the rear stage representing the interior of one house, and a stage door representing at the same time the exterior of another, especially when we find in court plays of the time unquestionable examples of the same thing, as, for example, in act V of Sapho and Phao, 
where Venus standing before Vulcan's forge actually sees Cupid sitting on Sapho's lap inside a chamber, or in The Three Lords of London, where all the action takes place before a prison and before and in the stall of the ballad-seller Simplicity. Gismond of Salerne, Misogonus, and Johan Johan have already been cited as examples of the same thing.

Keeping these plays in mind, let us turn to specific scenes of plays acted on the public stage. In Lord Cromwell, I, i, ii, the study of young Cromwell and the exterior of his father's shop are represented simultaneously. In Sir John Oldcastle, II, i, the first part of the scene takes place before the castle of Oldcastle. At line 632 (Malone Soc. Reprint) the characters are before an alehouse; at line 710 they are sitting in the ale house. In Arden of Feversham, I, i, the first part of the scene takes place before Arden's house. A painter, we are told, lives "hard by"; and at line 245 Mosbie says, "This is the painter's house; Ile call him foorth." He calls, and Clarke enters. At line 361 the characters are inside Arden's home, while at line 448 they are presumably again before the house. Why assume that a curtain "playing back and forth at the rear" carefully informed the audience when it was to imagine an interior and when an exterior scene? In The Two Italian Gentlemen, line 432, occurs this direction: "Heer let him either take a Flute or whistle, at the sound whereof Victoria comes to the windowe, and throwes out a letter, which Fedele taketh up, and reades it at the lamp which burneth in the Temple." Surely a curtain did not open at this point. When Fraunce wrote a Latin play using the same source as the author of the English play used, he thus directed the stage manager who was to stage his play at the university: "Quatuor extruendae sunt rlomus, nimirum: Fidelis, Fortunii, Cornelii, Octaviani. Quin et sacellum quoddam erigendum est, in quo constituendum est Cardinalis cuiusdam Sepulchrum, ita efformatum, ut claudi aperirique possit. In Sacello autem Lampas ardens ponenda est." "s1 When Monday's (?) play was presented on the regular stage, ${ }^{32}$ the door (curtain) of the sacellum (rear stage) was open when Victoria

${ }^{31}$ Smith's ed. of Victoria, p. 5 .

${ }^{32}$ It is usually said that the play was never acted. For evidence in favor of public presentation, see Malone Society, Collections, I, 3, 226. 
threw down her letter. Perhaps, as seems to have been the case with the sacellum, it remained open throughout the play.

Now if we find cases of the interior of one louse and the exterior of another being represented simultaneously in the same scene, we should not contend too strongly against the simultaneous representation of the exterior of a shop and a "town's end" as in George-a Greene, the interior of Capulet's house and a neighboring street as in Romeo and Juliet, the interior of a palace and a grove as in Greene's Alphonsus, or the interior of a queen's tent and an "unlocated place-perhaps the road to London," as in If You Know Not Me ${ }^{33}$ (p. 224). In such cases we are certainly just as much justified in believing that the stage represented two distinct places at the same time as we are in contending, as Albright does, that the curtain opens or closes at an opportune moment and the scene changes without the characters leaving the stage. ${ }^{34}$ In such situations if it was necessary that the curtain should close in order that the recess behind it could be provided with another setting to be used in a scene immediately following, then in all probability the curtain closed; if this was not necessary, then in all probability it did not close until the end of the scene or act, or even the end of the play for that matter.

ss For other examples of this sort of thing, see the works of Reynolds and Neuendorff, and the chapter on the stage in Creizenach's Geschichte, IV. Neuendorff notes that fewer examples occur in the later plays than in those before 1603 . It will be noted that his theory as to the development in Elizabethan staging and $\mathrm{my}$ own are similar; our reasons for such a development are entirely different. I have not considered it necessary to change this section of my study from the form it assumed before Neuendorff's work was accessible.

${ }^{*}$ Drawing a curtain to explain simultaneous setting is not a recent idea. Lemazurier in 1810 , attempting to explain the staging of the early French Drama, wrote: "Quand on voulait faire connaître au spectateur que le lieu de la scène allait changer, on levait ou on tirait une tapisserie, et cela se faisait jusqu' à dix ou douze fois dans la même pièce" (Quoted hy Rigal, Theat. fr., p. 243).

Fleay (Biog. Chron., II, 199-200) said that Meas. for Meas., III, i, ii, should not be marked as separate scenes since the traverse was drawn at the end of III, $i$, without the characters leaving the stage. Cf. also remarks on act IV of Henry IV (part 2). 


\section{COURT INFLUENCE IN GENERAL}

Such is my theory regarding the origin and development of the early public stage. It is of course only a theory. But in favor of such an idea may be urged the close connection that must have existed between the court and the regular stages and the various suggestions of court influence in the sixteenth century. May it not be said, too, that as a result of our belief in the great indebtedness of the public stage to the inn-yard and in consequence of an undue consideration of the court in our discussions of the Elizabethan theatres, we have overemphasized the erudity of such structures and the inconveniences which audiences and managers were willing to tolerate in the presentation of plays? There seems to be no reason for believing that the London stage waited until 1603 before it began to develop, or for supposing that the Elizabethan theatres were not as attractive and commodious as their owners knew how to make them. They were among the sights of London. The Theatre cost $£ 666$ 13s. 4d., the Fortune only $£ 520$. The Swan was impressive enough to deceive the eyes of DeWitt. Weever in his epigram apparently gave it precedence over the theatres of Rome. Michael Drayton ${ }^{1}$ in 1594 referred to "our stately stage"; White ${ }^{2}$ in 1578 spoke of the "sumptuous theatre houses a continual monument of London's prodigalitie and folly"; and Stockwood referred to the "houses of purpose built with great eharges," the "gorgeous Playing place erected in the fieldes." Ev. B. in his poem on Jonson's Sejanus has the words:

"When in the Globe's fair ring, our world's best stage,
I saw Sejanus set with that rich foil."

Coryat in his Crudeties, 1611, declared that the theatres of Venice were "very beggarly and base in comparison of our stately playhouses in England"; and Dekker in his Belman of London $(1608)^{3}$ mentioned the very ambitious strollers who "forsake the stately and our more than Romaine Cittie Stages, to travel upon ye hard hoofe frõ village to village for chees \& butter-milke." Spenser in his Tears of the Muses (11. 176-7) spoke of "painted

1 Shakspere Allusion Book, 1, 15.

${ }^{2}$ Quoted by Wilson, Life in Shakespeare's England, pp. 177-78, and elsewhere.

${ }^{3}$ Ed. Grosart, p. 81. 
theatres"; Harvey ${ }^{4}$ in a letter of 1579 referred to "the Theater, or sum other painted stage" ; while Gosson in his Plays Confuted ${ }^{5}$ complained that to please the eye the devil, "beeside the beautie of the houses and the Stages", sent in "Gearish apparell" and similar things. And finally in view of such references, the various entries in Henslowe's Diary of payments to painters cannot be dismissed with the statement that he "had probably found that unpainted wood will not resist the weather." ${ }^{6}$

Alongside these passages should be placed some which indicate that something else besides the "painted stage" " and the beanty of the houses was being employed to appeal to the Elizabethan love for show and pomp. Gosson in his Plays Confuted" laments the "waste of expences in these spectacles," "this glittering, this pompe, this diligence in setting forth of plaies"; and he asserts ${ }^{9}$ that nothing is forgotten "that might serve to set out the matter with pompe, or ravish the beholders with variete of pleasure." The Preface to the Second and Third Blast of Retrait ${ }^{10}$ promises dire evil to those who do not "shun plaies, with such like pompes of Satan"; and Cross in his Tertues Commonwealth" (1603) declares that plays "feed the eare with sweete words" and "the eve with variable delight." The author of the Third Blast ${ }^{12}$ asks if the eye. at theatres is not "carried awaie with the pride of vanitie." There seems to be no reason for thinking that even Jonson ${ }^{13}$ is especially ironic when he has Valentine remark that in England both tragedies and comedies are "set forth with as much state as can be imagined." Of more significance are Nash's boast ${ }^{14}$ that "our sceane is more statelye furnisht than ever it was in the

4 Letter-Book (Camden Soc.) pp. 67-68.

5 Hazlitt, Eng. Drama and Stage, p. 192.

${ }^{\circ}$ Ordish, London Theatres, pp. 156.57.

${ }^{7}$ A passage translated in Heywood's Apology, p. 22, may be of interest in this connection:

"Then [in time of Romulus] was the tragicke stage not painted red, Or any mixed staines on pillers spred".

${ }^{8}$ Hazlitt, Drama and Stage, pp. 199-200.

- Ibid., p. 192.

${ }^{10} \mathrm{Hazlitt}$, Drama and Stage, p. 100.

11 Ed. Grosart, p. 120.

12 Drama and Stage, p. 129.

1s Case Is Altered, II, iv.

${ }^{14}$ Pierce Pennilesse, ed. McKerrow, p. 215. 
time of Roscius," and Vennor's explanation ${ }^{15}$ as to why he advertised his England's Joy in 1602 as an especially spectacular performance. "I saw daily," he says, "offering to the God of pleasure, resident at the Globe on the Banke-side, of much more then would have supplyed my then want: I noted every mans hand ready to feed the luxury of his eye, that puld downe his hat to stop the sight of his charity, wherefore $I$ concluded to make a friend of Mammon, and to give them sound for words."

And Brathwaite asks in his Remains after Death (1618):

"What Theatre was ere erect'd in Rome, With more ambitious state, or eminence, Then the whole Theaters we have of some, Where there's nought planted save sins residence: The Flagge of pride blazing th' excellence Of Albyon's vanitie?"

Surely such passages are not all to be explained away on the ground of patriotism or Puritanism. Some of them are no doubt exaggerated, but certainly no more so than the bits of satire which have time and time again been cited to show the crudity of the platform for which Shakespere wrote.

And other matters must be considered in an attempt to ascertain the conditions under which plays were presented in the regular London theatres. In the first place, the conveniences and equipment were of course entirely different when the actors were at home from what they were when they traveled in the provinces and on the continent. Barn-stormers were scoffed at then as they are today. We have already cited Dekker's assertion that certain vanity stricken actors were inclined to leave the more than Roman city stages in order to act leading rôles in the provinces. Perhaps the most famous passage in this connection is the often quoted statement of Fynes Moryson: "So as I remember that when some of our cast dispised stage players came out of England into Germany, and played at Franckford in the tyme of the Mart, having nether a complete number of actours, nor any good apparell, nor any ornament of the stage, yet the Germans, not understanding a worde they sayde, both men and wemen, flocked wonderfully to see theire gesture and action, rather than heare them, speaking English which they understoode not, and pronouncing peeces and

${ }^{15}$ Collier, Illustrations of Old Eng. Lit., III, p. 9. 
patches of English playes, which my selfe and some English men there present could not heare without great wearysomenes." 16

Much later Donald Lupton ${ }^{17}$ wrote that when actors "flye into the country," it is "a suspicion that they are either poore or want cloatlies, or else company, or a New Play."

Perhaps the inconveniences that naturally beset the traveling troupes should be borne in mind when we read such plays as Narcissus; or such directions as "Exit Venus, or if you can conveniently, let a chair come down from top of the stage and draw her up" (Greene's Alphonsus); or the one in John a Kent and John a Cumber, which requests that a spirit be allowed to appear out of a tree, "if it can be." There is little doubt that such things were "convenient" in the regular London theatres long before 1603.

In the second place, it should be noted that while sign-boards were unquestionably used on the early stage, their use does not mean that more pretentious properties were not employed. The custom of titling properties as well as pageants and plays, and characters in pageants, masques and plays, is at least as old as the reign of Henry VIII at whose court the most elaborate and gorgeous structures were duly labeled. This is revealed in the large "pas" prepared by Gibson ${ }^{18}$ in 1515 , "kawlld the wrythyng there over, the Pavyllyon un the Plas Parlos"; the magnificent castle shown at Greenwich in the second year of his reign with the title "le Fortresse dangerus" written on its front; ${ }^{19}$ and the "castle of cole blacke" titled "The dolorous Castle" which was employed the following year in the tourney at Greenwich..$^{20}$ That

1t Shakespeare's Europe, ed. Hughes, p. 304.

${ }^{17}$ Country Carbonadoed (Aungervyle Soc. Reprints, second series, p. 759). For other references to the "cast dispised" players in the provinces, see Jests of Peele, Bullen's ed. of Peele, II, 389; Dekker's Newes from Hell, ed. Grosart, p. 146; Dekker's Wonderful Feare, ed. Grosart, p. 100.

18 Brewer, II, p. 1501.

19 Hall, Chronicle, p. 526.

${ }^{20} \mathrm{Ibid} .$, p. 533. The prison of Discord in 1562, "Extreme Oblivion", "Castell Loy all", and "Fortresse of Perfect Beautie" used in the tourney of 1581, etc., were no doubt titled. (cf. Reyher, p. 379, Brotanek, 27-28). In this connection should be mentioned the payment to "Wm. Smythe for ayall paper inke and colores for the wryting of greate letters" for the Latin comedies at Westminster School in 1564 (Murras, II, 168), and the entries in the Revels Accounts "for the Garnyshinge of XIIII titles" (Feuillerat, p. 328) and for the "Painting of IX titles with copartmentes" (ibid., p. 338), some of which may have been titles for properties. (cf. Reynolds, Some Principles, I, 21; W. J. Lawrence, Sh. Jahrbuch, XLV, pp. 148, 149). 
this practice was not confined to the sixteentl century is shown by the "Honoris Fanum," of Chapman's Masque (1613), the "Lovers' Valley' of Tatham's pastoral (1632), the titled altar in Jonson's Hymenaei, and other evidence.

The gorgeous pageants prepared for the coronations of sovereigns were regularly titled. The first pageant ${ }^{21}$ approached by Elizabeth in 1559, for example, bore the inscription, "The uniting of the two houses of Lancaster and Yorke,' while the pageant in Fleet Street on the same occasion was similarly titled. ${ }^{22}$ When James I entered London in 1603, "Londinium" was written over the battlement, or first gate, approached by him, while beneath the word above was written in smaller letters, "Camera Regia." The pageant at Soper Lane was titled "Nova Faelix Arabia," 23 etc.

This Elizabethan passion for inseription is illustrated, not only by motto-bedecked arras, walls and pageants, by labeled gateways and pageants, but by labeled characters as well. And in some cases at least the people of the day in their desire to be understood went to what appeals to us as being ridiculous extremes. Writing the naine across the back and breast of so well known a character as the Devil is a case in point." "Having tolde you that her name was Justice," says Dekker, in describing a pageant at the coronation of James, "I hope you will not put me to describe what properties she held in her hands, sithence every painted cloath can informe you.", 25 Yet on occasion Justice as well as Time was labeled. One of the pageants at the coronation of Elizabeth contained a very fair tree "with leaves as greene as arte could devise." At the top was set a table with the words, "A palme tree." 26

Certain abstractions were difficult to costume. The Elizabethans, however, were not willing to be misunderstood. Explanatory speeches and tables were considered necessary, but suggestive

21 Holinshed, IV, 161.

${ }^{22}$ Ibid., p. 170.

${ }^{29}$ Dekker's account, Nichols, Prog. of Eliz., ed. 1805, III, pp. 52, 61.

${ }^{24} \mathrm{Cf}$. Like Will to Like.

${ }^{25}$ Nichols, Prog. of Eliz., III, 74. For other examples of titling characters in plays, masques and pageants, see Spenser's Fairy Queen, III, 12, iv; the description of Elizabeth's coronation in Nichols, ed. 1823, I, pp. 41-50; Dekker's account of entry of James, p. 58; Hall's (hronicle, pp. 582, 631; Pollard, Fifteenth Century Prose and Verse, p. 312 ; Dekker's Old Fortunatus; Literary Remains of Ed. VI, p. cexci; Collier, Hist. Dram. Lit., 1, 82; Reyher, Les Masques Anglais, 'pp. 5, 11, etc.

${ }^{26}$ Nichols, Prog. of Eliz., I, 53. 
accessories were also used. This is brought out especially well in the description of the pageant at Cornhill on the occasion of Elizabeth's coronation: "Eche of these personages [Wisdom, Pure Religion, Follie, Adultery, etc.], according to their proper names and properties, had not onely their names in plaine and perfit writing set upon their breastes easily to be read of all, but also every of them was aptly and properly apparelled, so that hys apparell and name did agree to expresse the same person that in title he represented." 27

Now what has all this to do with Elizabethan stage properties? Just this, it seems to me. If inscription is to be considered a crudity, then it is to be regarded as a crudity of the era and not of the public stage. Such references as those cited above tend to show, too, that above all things the people of the period were striving after clearness in their "shows," a feature further illustrated in explanatory prologues and soliloquies, choruses, irrelevant speeches, repetitions, and the self-revelations of characters whose names are already well known to the audience. This being true, the use of signboards in an age when programs were unknown and titling was a fashion by no means shows that before 1603 elaborate properties were infrequent on the London stages and their places supplied "with their Nuncupations onely in Text Letters." And there is always the possibility, too, that even stage directions so capable of being suspected as "Enter-from the Numidian mountaines," "Enter at Coleharbour," "Enter from the forest" refer to something more elaborate than bits of Elizabethan editing or stage-doors provided with sign-boards.

Again, the words of various writers regarding the limitations of the stage do not argue for primitive conditions any more than they show that the age was demanding more than the stage-Elizabethan or twentieth century-could present. Battles, for example, are ridiculed by Sidney and Jonson, and the inability to present them adequately is referred to by Shakspere and the author of The Play of Stucley (11. 2658-61); yet there is much reason for believing that the Elizabethans knew how to present such things as realistically as various companies present them at the present time. At any rate, in the "understanding age" that followed the Eliza-

${ }^{27}$ Ibid., I, 44-45. 
bethans, battle scenes were still objectionable to the satirist. ${ }^{28}$ Nor is it an especial discredit to the Elizabethan public theatre that it could but lamely "expresse a sea," as Heywood puts it. ${ }^{29}$ Inigo Jones and his workers at court did not always succeed in their expression of the same object. "There was a great engine at the lower end of the room," wrote Sir Dudley Carleton, ${ }^{30}$ describing Jonson's Masque of Blackness, "which had motion, and in it were the images of sea-horses (with other terrible fishes) which were ridden by the Noors. The indecorum was, that there was all fish and no water."

Elizabethan expressions of storms, rain, descending clouds, blazing stars and comets, flaming heavens, brazen heads that speak and flash fire, fire-shooting monsters, trees and arbors that spring from the ground, mists, flying gods and animals, rivers, brooks,all may have been lamely expressed from our point of view or that of Sir Dudley Carleton, but they are hardly the things to be expected on a careless and unprovided stage. The mere fact that managers were attempting to reproduce such things indicates what the audience was demanding and what the theatres were doing in order that nothing might be forgotten which "might serve to set out the matter with pompe, or ravish the beholders with variety of pleasure.",

Nor can stage directions indicative of ingenuity be dismissed with the assertion that they are the additions of printers with a sense for business. A tendency to do this is seen even in Neuendorff's treatise, which to a greater degree than most discussions recognizes the well-equipped condition of the Elizabethan propertyroom and the adequate presentation of spectacular plays. Writing, for example, of the stage direction in Tamburlaine (pt. II, III, 2)-_" and the drums sounding a dolefull march, the Towne burning"'-Neuendorff (p. 155) regards the last words as episch. A few torches, he says, on the upper stage would have sufficed to symbolize the conflagration. He is perhaps right in supposing that a town of painted canvas was not brought into use at this particular point, but it is not at all probable that the Elizabethans, accustomed

\footnotetext{
${ }^{28}$ Dryden, Essay on Dramatic Poesy, ed. Ker, p. 62.

${ }^{29}$ Fair Maid of the West, chorus at end of Act IV.

${ }^{30}$ Nichols, Prog. of James, I, 473.
} 
to the most elaborate fireworks in pageants, processions and "shows," would have tolerated such a lame expression of a burning city as that suggested above, especially in such a grandiloquent performance as Tamburlaine. Similarly, he says (p. 175) of the direction in A Looking Glass for London- "Jonas the Prophet cast out of the whale's belly upon the stage" - "Ein Sprung zur Tür hinein war sicher die einzige Verkörperung der sehr epischen Anweisung."

Some of the directions in this particular play are, I admit, singularly descriptive, still I for one prefer to accept them at their face value and believe that in this extremely spectacular performance a fair arbor actually arose when the Magi beat the earth with their rods, that Radagon was "swallowed" by fire as the vine was by the serpent in the same play. And above all things, is it to be expected that such an unspectacular representation of so famous a story as that of Jonah and the whale would have been tolerated by an audience boisterous and free with pippins, uncontaminated as yet by Higher Criticism, and acenstomed from infancy to such things as hell-mouths and monsters of brown paper? And to my mind, it is the less fortunate companies, which were willing to adopt such extremely symbolic methods as to represent a whale by a stage door or a forest by a twig, ${ }^{31}$ that in such plays as Narcissus,

s1 Neuendorff (pp. 170-171) in opposing Reynolds's idea that painted cloths were regularly used in representing groves and forests, argues that such things were fre quently suggested by a single tree. To be sure, the existence of numerous practicable trees on the Elizabethan stages cannot be proved from Henslowe's inventory or from stage directions, but forests are just the things that would not have been represented by such articles. Practicable trees were apparently rare in court plays and even in masques. They are rare on any stage. Neuendorff may of course be right, but the chief bit of evidence cited in favor of his theory by no means supports it. He quotes the prologue to Heywood's Woman Killed with Kindness, and remarks that when the prologue speaker uttered the words, "We could afford this twig a timber tree", he pointed to the "twig" which was placed on the stage before the play opened and which later on served for a grove. The line is figurative, however, as the following lines of the passage show. In his prologue to Fair Maid of the Exchange Heywood similarly uses the word "twig" in a figurative sense:

\footnotetext{
"Meane while shore up your tender pamping twig,

That yet on humble ground doth lowly lie:

Your favours sunneshine guilding once this sprig,

It may yeeld Nectar for the gods on hie;

Though our Invention lame, imperfect be,

Yet give the Cripple alms for charity."
}

The Elizabethans represented the interior of a house by an arras-bedecked stage set with a table and four chairs, they laid siege to the tiring-house, etc., but these things are hardly analogous to the "symbolizing" of a forest by the song of a bird, a twig, a "Timber tree", or even two "bowes". 
John a Kent and Midsummer Night's Dream are being burlesqued, just as much as the unimaginative souls are being satirized who insist on the actual performance of moonlight and who refuse to accept a bucket for a well.

Perhaps after all the Elizabethan imagination was not the child-like, all-sufficing thing that it was once supposed to be. Perhaps, too, it was not so capable of being aroused as we have sometimes thought. Poets were using poetry to arouse the imagination of their audiences, but they were likewise resorting to other appeals. Shakspere, for instance, gives a description thrilling enough, when properly spoken, to arouse the imagination of any of us; yet at the opportune moment an alarm is sounded, chambers are discharged, and Henry $\mathrm{V}$ speaks his famous oration before the walls of Harfleur. The description of a wreck occupies two pages in A Looking Glass for London, IV, i, still the character who utters it and the persons who accompany him enter "wet from the sea." Gory hands and faces, blood that follows the stab, the destruction of properties for realistic effect, "a great skirmish in Rome and long," the crowing of cocks, even the cry of invisible prisoners in the Marshalsea or "a noise within of driving beasts" may all appeal to our modern senses as being somewhat ridiculous. Even the singing of birds, the continued ringing of bells during the massacre of St. Bartholomew, the tramping of horses, the sound of hammers in a forge, "Allarums afar of," "Drummes afar off marching" may perhaps be questionable as suggestive devices; yet they at least imply that the dramatists and actors of the times were not leaving everything to the imagination, and that they were using means other than the beauty of their stages, spectacnlar devices, and "gearish apparell" to eatch and hold their London audiences.

Under such circumstances, then, when rival dramatic companies who, as Dekker ${ }^{32}$ has it, "salute one another like sworne brothers" at the beginning of a theatrical season, "yet before the middle of it, shall they wish one anothers throats cut for two pence," when such companies were obviously putting forth every effort to please their patrons, it is certainly to be expected that they should have taken advantage of their experiences at court and their rehearsals for

82 Raven's Almanac, ed. Grosart, pp. 210-211. 
court performances, and that they should have flattered their audiences with glimpses into the method of doing things at the centre of dramatic activities. Nor is it probable, as was suggested above, that their audiences would have always remained contented with the cruder presentations necessitated on improvised stages. They themselves, even the most humble, had looked upon the pageants, processions and "princely pleasures" devised to entertain the splendor-loving daughter of Henry VIII in an age characterized by extravagance and richness. The host of workmen employed at court entertainments served as a natural medium for advertising the wonders of performances before the Queen. Some of the frequenters at least of the London theatres, exclusive of gallants, had themselves probably been privileged to gaze upon the splendor of court amusements $;^{33}$ and all London was naturally curious regarding the methods employed in entertaining Elizabeth and her Court.

This curiosity is brought out most strikingly perhaps by the notorious England's Joy of 1602, advertised "to be acted only by gentlemen and gentlewomen ${ }^{34}$ of account" with the attendant splendor, a show which in spite of the enormously high price of admission "drew more Connies in a purse-nette than ever were taken at any draught about London." ${ }^{35}$ And later when Vennor wrote an apology for his earlier conduct, he used the very significant words: "The report of gentlemen and gentlewomens actions, being indeed the flagge to our theatre, was not meerely falcification." ${ }_{36}$

Nor must we overlook in this connection the gallants themselves, who from an early date ${ }^{37}$ were regular frequenters of the public theatres. These gentlemen at least were accustomed to the "doings" at court; and whereas it became a convention for

${ }^{83}$ Reyher, Les Masques Anglais, pp. 37, 41-44; Dekker, Worke for Armorours, ed. Grosart, p. 131; Peregrinatio Scholastica, ed. Bullen, p. 77; Hall, Chronicle, p. 519 ; Evans, Eng. Masques, Introd., p. 1.; Davidson, Greene in Conceipt (Grosart, Occasional Issues, VI, 40).

${ }^{34}$ Letters of Chamberlain, Camden Soc., p. 163. Apparently, the advertising of the acting by "gentlemen" had served at an earlier date to draw a crowd. Cf. Hazlitt, Shakespeare Jest Baoks, ed. of 1881, Pt. 2, pp. 145-7.

${ }^{35}$ Travailes of the Three Eng. Brothers, Bullen's ed. of Day, 56.

${ }^{86}$ Collier, Illustrations of Old Eng. Lit., III, 10.

${ }^{37}$ I give here for what it is worth a curious passage from Edmund Bohun's Character of Queen Elizabeth, (Nichols Prog. of Eliz., ed. 1788, II, 48): "The coming of the Duke of Alençon into England opened a way to a more free way of living . . . . . 
satirists to ridicule their conduct at the play, it is virtually certain that the managers of the time strove to satisfy their courtly demands in ways other than building rooms fit for gentlemen and allowing them to occupy the stage, as they had seen their superiors do at private performances, a privilege in itself suggesting court influence.

Such circumstances as these certainly imply that the regular companies took advantage of their experience at court; yet when one attempts to say just what they received there and what they did not receive, the task is dangerous if not impossible. This is especially true with respect to "scenery." Regarding the use of painted cloths and painted canvas stretched on frames at the regular theatres before 1603 , I am as yet able to add little or nothing to the discussions of Baker, ${ }^{38}$ Schelling ${ }^{39}$ and Neuendorff; ${ }^{40}$ and while I can in no sense prove the common employment of such things at the Curtain, Globe, or even at the Blackfriars, I believe that in view of what has preceded they were much better known at these places than we are prone to admit. The peculiar structure of the stage made unnecessary any extensive use of "howses," "battlements," etc., so common at performances at court; yet for reasons already given, it would seem that when separate structures were called for in particular plays, they were surely used.

I would not say that scenes in the modern sense were employed at the public theatres, but as Professor Baker has noted, it is extremely probable that painted "drops" were often called into use.

\footnotetext{
the Queen danced often then, and omitted no sort of recreation, pleasant conversation, or variety of delights, for his satisfaction: at the same time the plenty of good dishes, pleasant wines, fragrant ointments and perfumes, dances, masques and variety of rich attires, were all taken up, and used, to shew him how much he was honoured. There were then acted comedies and tragedies with much cost and splendor: from whence proceeded in after-times an unrestrainable desire of frequenting these divertisements; so that there was afterwards a greater concourse at the theatre, than at the sermon. When these things had once been entertained, the courtiers were no more to be reclaimed from them; and they could not be satiated or wearied with them. But when Alençon was once dismissed and gone, the Queen herself left off these divertisements, and betook herself, as before, to the care of her kingdom." I have not seen Bohun's source, R. Johnstone's Historia Rerum Brittannicarium (1665).

ss Shakespeare's Development, pp. 96-8.

${ }^{29}$ Eliz. Drama, I, 172-75; Pub. of Numismatic and Antiquarian Soc. of Philadelphia, 1910, pp. 153.4.

*o Volksbühne, Chap. VIII.
} 
In favor of such "scenery" may be cited the "piece of perspective" referred to in Cynthia's Revels, the "painted stage" of Spenser and Harvey, together with other early allusions to the beauty of the playhouses, Henslowe's "Sittie of Rome," his payment of twenty shillings to the "paynter of the propertyes for the playe of the iii brothers," ${ }_{41}$ and the discussion above of the "heavens." It is possible, too, that the later hand, perhaps Malone's, is not entirely right in interpreting as "Tassos Picture" the entry in Henslowe's Diary, "lent unto $\mathrm{w}^{\mathrm{m}}$ borne the 14 of July, 1598, for to geve the paynter in earneste of his picter." 42

The cost of such decorations need not worry us. ${ }^{42 a}$ Nor is there much diffeulty in providing places for them in the public theatres. Professor Baker suggests that they could be suspended at the rear of the upper stage. They could also be suspended at the front of it, as in Loves Letamorphosis where a curtain painted like a cloud probably concealed the upper stage. ${ }^{42 b}$

And is it assuming too much to suggest that hangings or tapestry painted to represent a "city," for example, or a forest, could have hung before the "fore-front" of the Elizabethan stage; that is, could, on occasion, have hung before the side doors or have taken the place of the lower curtain? Similar cloths sometimes adorned the sliene of the Attic theatre. ${ }^{43}$ On the early Renaissance platform in Italy the decorative back-cloth was frequently painted in perspective to represent a street or landscape. ${ }^{44}$ According to Drake, ${ }^{45}$ the hangings in Elizabethan houses were adorned with landscapes as well as pictures of historical events.

41 Diary, ed. Greg, I, 184.

42 Ibid., p. 90. Describing the letter of Sept. 28, 1593, from Henslowe to Alleyn, Greg says that there are "several pen and ink sketches on the outer leaf, one apparently for some scenery in perspective" (Henslowe Papers, p. 39). It would be fortunate if we could discover the author of this sketch.

42a Reynolds, Mod. Phil., IX, 78.

22b $\mathrm{Cf}$. in this connection the curtain painted like a cloud which opened before the pageant at James's entry into London, the "double vale so artificially painted that it seemed as darke cloudes had hung before it" which concealed the stage in Campion's Masque in honor of Lord Hayes, the traverse which "served as a curtaine for the first Scene" in Daniel's Tethys Festivall and which "was figured a darke cloude, interior with certaine sparkling starres".

43 Haigh, Attic Theatre, 3rd ed., chap. IV.

4t Mantzius, Hist. of Theatrical Art, II, 224, 321. For conditions in Spain seo Rennert, Spanish Stage, 89.

t5 Sh. and His Times, II, 114. 
That painted cloths which could fall or be drawn aside were used in theatrical performances of the time, there can be no doubt. ${ }^{40}$ The painted cloth which fell in the reign of Henry VIII is perhaps an example. ${ }^{47}$ The curtains painted like clouds referred to above are cases in point. Similar to what the public stages surely could have approximated are the "landstschap" consisting of "small woods, and here and there a void place filled with huntings," which fell in Jonson's Masque of Blackness exposing an artifical sea, and the "travers painted in perspective, like the wall of a Cittie with battlements, over which were seene the tops of houses," which was drawn in The Masque of Flowers, thus revealing a "Garden of Glorious and strange beauty." Possibly the use of painted cloths to represent wood scenes, decorations as cheap as practicable trees and more easily handled, helps to explain why in the plays of the period we have reference after reference to groves and few cases where the existence of practicables can be actually proved.

I am aware of Flecknoe's assertion that the theatres of Elizabethan England "were but plain and simple, with no other scenes nor decorations of the stages, but only old tapestry," and of Corey's words, "Coarse handings then instead of scenes, were worn." Tapestry, then, according to these persons, regularly served for scenes. Perhaps the fact that cities or forests were suspended on the stage rather than rolled or shoved in was what appealed to these gentlemen as being especially simple and primitive. Their scenes would probably seem equally primitive to us.

High-sounding descriptions and elaborate gestures directed at such painted eloths-not necessarily perspective-do, I admit, appeal to us as being rather absurd, but no more so, it seems to me, than if they were directed at a bare wall or a titled stage door. Some of us perhaps would wish that the Elizabethans had been satisfied with poetry alone, but that this was actually the case is not at all probable. "And the arke must be borded rounde about," reads a direction in the Chester Deluge, "48 "and one the bordes all the beastes and fowles hereafter receaved, must be painted that thes wordes may agree with the pictures." It is at least probable

\footnotetext{
4 Regarding canvas painted in perspective at court, see Neuendorff, pp. 151 ff.; Feuillerat, Le Bureau, pp. 51, 68, 70; Mrs. Helmholz-Phelan, P. M. L. A. XVII, 203.

${ }^{47}$ Cal. State Papers, Venetian, 1527-33, p. 60.

48 Ed. Diemling, 1. 54.
} 
that in some of the more detailed Elizabethan descriptions a similar care was taken that the "wordes may agree with the pictures." And the Renaissance love for word-painting, it may be noted too, manifests itself even in court plays where "scenery" was certainly employed.

We are perhaps on firmer ground in the discussion of other indications of court influence before 1603 , or even before the fitting up of the Blackfriars in 1597, which Professor Wallace argues, heralds a new era in the dramatic activities of London. The elaborate processions with their display of heraldry and costume, and the spectacular dumb shows of the period were first used to please the eye of Elizabeth with her inherited love for pomp, pageantry and chivalric exercises. And such features, it must be remembered, occur in plays presented long before 1603, as Locrine, Knack to Know an Honest Man, James IV, Tamar Cam, Three Lords of London, and Battle of Alcazar.

The frequency of "shows" is revealed by other evilence. Gosson in his Plays Confuted ${ }^{49}$ mentions as one of the tricks of the day the "wringing in" "a shewe to furnish the Stage when it is to bare"; and the misplaced prologue to The Wars of Cyrus (1594) exclaims with Marlowe as model:

\section{"Againe with toies}

Or needlesse antickes, imitations,

Or shewes, or new devices sprung a late,

We have exilde them from our Tragicke stage,

As trash of their tradition, that can bring

No instance nor excuse for what they do." so

Even the more dignified masque, which throughout the century had been presented at court in connection with plays, seems to have been practiced in the regular theatres at an earlier date than is sometimes assigned. Says Professor Wallace, "these masques within the play at Blackfriars were a wholly new feature in the evolution of the drama." Is this entirely true? Among the things, according to Gosson, with which the devil was wont to

49 Hazlitt, Eng. Drama and Stage, p. 188.

${ }^{50}$ On the dumb shows of the period, see Rerher, Les Masques Anglais, 313 ff., F. A. Foster, Dumb Show in Eliz. Drama before 1620, Eng. Stud., 44, pp. 8-17.

51 Children of the Chapel, p. 119. Since the paragraph abore was written the new discoveries regarding the earlier Blackfriars have been made, and Professor Wallace's Evolution of the English Drama has been published. 
please the frequenters of theatres are "Gearish apparell, maskes vanting, tumbling, daunsing of gigges, galiardes, morices, hobbihorses." ${ }_{52}$ And evidence of masque influence is surely to be detected in Greene's James IV, V, 2; Romeo and Juliet; Love's Labour Lost, V, 2; Spanish Tragedy, I, 3; Death of Robert Earl of Huntington, II, 2.

The "hunting scene", practiced at an early date to appeal to the Queen's fondness for the chase ${ }^{53}$ the echo ${ }^{54}$ and the singing of birds ${ }^{55}$ as theatrical devices; the dancing of nymphs and the flying of gods and goddesses-all these things are at least heard of first in connection with court entertainments; and before 1603 they had all made their appearance upon the regular stages. They do not necessarily show court influence, to be sure, but they are of service in showing that the people of the day were receiving something else besides sword play and tumbling, and that the managers of the time were exerting their ingenuity and income to present from whatever sources possible effects and devices that would take with their London audiences. And what if the hobbyhorse was not forgot, or noise and buffoonery remained attractive? This does not prove a taste essentially different from that at court, where grotesque dances, clownage, tumbling, sword-play (of a more refined sort, perhaps) and even bear-baiting were apparently relished throughout the century.

${ }^{62}$ Hazlitt, Drama and Stage, p. 192. On Masques in plays, see Reyher, Les Masques Anglais, pp. 315 ff., 497-98; Symond's Shakespeare's Predecessors, p. 254; Brotanek, Eng. Maskenspicle, pp. 98-100; Collier, Annals, 1, 24; Thorndike, Pub. Mod. Lang. Ass'n., VIII, pp. 114-120; Rena May Odell, The Masques in Shaliespeare's Plays (Master's Diss., Univ. of Chicago, 1911.

${ }^{53}$ Cf. Cal. State Papers, Spanish, 1558-67, pp. 466, 609, 672; ibid., 1568-79, pp. $410,497,531,533,697$; Lanebam's account of Kenilworth entertainments, Nichols, Prog. of Eliz., I, pp. 12, 14.

64 For echo in dramatic and non-dramatic literatuse, cf. Baskervill, Eng. Elements in Jonson's Comedy, p. 246; Reyber, p. 168; Ward, Hist. Dram. Lit., I, 417; Creizenach, Geschichte, IV, 397; Greg, Pastoral Poetry, pp. 199, 343.44, etc. Cf. especially the burlesque of the device in Narcissus and Returne from Parnassus (Pt. II), II, 2.

* Perhaps this device should not be mentioned here. I have found only one case of it before 1603 in public theatres. Possibly it was a specialty of the choir boys. A passage in Dekker's description of James I's entry seems to indicate that the chirping of birds was sometimes represented by more complex instruments than "pot birds". In one pageant, he writes, a song was sung "to a loude and excellent musicke, composed of violins, and another rare artificiall instrument, wherein, besides sundrie severall sounds effused (all at one time), were also sensibly distinguisht the chirpings of birds". (Prog. of Eliz., III, 64-5). The frequency of bird songs and the echo at court performances seems to indicate that the devices were used to heighten the effects of wood settings rather than to take their place (cf. Mönkemeyer, Prolegomena, 82). 
We all agree that the costumes worn by Alleyn and Burbage in their public performances were often elaborate and costly. Instead of attributing the purchase of these garments entirely to the vanity of the actors or a desire to replace painted scenery by gorgeous apparel, one may well ask if the necessity of appearing at court in appropriate and acceptable costume had anything to do with the buying of these same costly garments.

Maas ${ }^{56}$ and MIrs. Helmholz-Phelan ${ }^{57}$ write that in performances at court all the costumes and properties were furnished to the regular players by the Revels Office. This, however, was certainly not always the case, especially in the latter part of Elizabeth's reign.

At an early period it seems that the costumes of regular players were sometimes used at court performances. One of the questions in the Rastell-Walton lawsuit of cir. 1530 reads: "Item, Whether about 3 or 4 years now past, about which time the King's great banquet was at Greenwich, which this deponent saw, the said garments were occupied there, some in divers stage-plays and interludes, by the letting to hire by Walton, as it was reported, and at that time they were fresh and new, and seemed little the worse for any wearing of them before." ${ }_{58}$ In the charges of the King's Revels (38 Henry VIII) occurs the entry: "To the king's pleyers, in rewards for loan of garments, $5 \mathrm{~s}$." 59

Numerous later payments indicate that players at court furnished at least part of their equipment. On February 22, 1573, "Therle of Leicester's Players" were paid $£ 613 \mathrm{~s}$. $4 \mathrm{~d}$. for a play on February 20, "and further by waye of Her Majesties reward for such charges as they had been at in the furniture of the same 66.8." 60 On February 11, 1578, a payment was made to the same company "for making their repaire to the Courte $w^{\text {th }}$ their whole company and furniture to presente a play before her Matie." In

68 Geschichte der Theatertruppen, p. 263.

б7 Pub. Hod. Lang. Ass'n., XVII, 194.

68 Pollard, Fifteenth Century Prose and Verse, p. 314.

${ }^{60}$ Kempe, Loseley Manuscripts, p. 71. Cf. also Archaeologia, XTIII, 333, and Col. lier's comment, Annals, 1, 118, note. Not very clear is the letter of John Husse to Lady Lisle on April 7, 1539, stating that players' garments in his possession had been damaged by the wet and "by your command I am bound in $10 £$ for it" (Letters and Papers of Henry FIII, XIV, Pt. I, p. 350).

${ }^{\circ 0}$ Stopes, Tm. Hunnis, p. 320. 
"consideration of their chardgies for that purpose," they received $£ 6$ 13s. 4d., but not the "more reward," because their play was not presented. ${ }^{61}$ Under a warrant dated April 20, 1603, twenty pounds are given John Hemynges and the rest of his company "for their paines and expences" for two plays before Her Majesty; and on April 22, of the same year Alleyn and his company are granted thirty pounds "for their paynes and expences" in presenting three plays before the Queen. ${ }^{62}$

Various entries in Henslowe's Diary refer to garments, etc., bought for court performances. On January 8, 1597-8, 30s. were lent to the company "when they fyrst played dido at nyght;" and under January 3, occurs the entry, "Layd owte for copr lace for the littell boye \& for a valle for the boye a geanste the playe of dido \& eneus." 63 On January 2, 1600, Wm. Bird was lent 20s. "for divers thinges a bout the playe of fayeton for the corte"; ${ }^{64}$ and on December 25, 1601, 13s. were lent at the appointment of the company to "the lettell tayller" to buy "taffty sasenet to macke a payer of hosse for nycke to tumbell in be fore the quen." ${ }_{65}$ John Thare was lent 10s. on January 1, 1602, "to geve unto mrs. calle for ii curenets for hed tyers for the corte." ${ }_{66}$

Some of the Revels Accounts speak of plays being "thoroughly furnished" in the office. Others speak of them as being provided with "divers" or "sondrey" things. ${ }^{67}$ In view of what has preceded, this distinction in phraseology is probably of some significance.

Such entries as the following are common in Fenillerat's Documents of the Revels: "For a carr to cary stuff for the Erle of Warwick his men." But such references as this also occur: "For the Cariadge of the Erle of Warwick his mens stuffe from the Revelles to Whitehall and back again." It is possible, therefore, that all such entries refer to the carriage of Revels property. One entry,

${ }^{61}$ E. K. Chambers, Mod. Lang. Review, II, 6.

${ }^{62}$ Cunningham, Extracts, p. XXXIV. For similar payments for "Pains and expenses", see p. XXXV.

${ }^{63}$ Ed. Greg, 1, 83. Perhaps reference to "dido at nyght" not a reference to a court performance. Cf. C. W. Wallace, Eng. Stud., XLIII, p. 377.

4t Ibid., p. 125, (cf. payment on Jan. 26, 1598.9, p. 83).

abid., p. 152.

${ }^{60}$ Ibid., p. 186. Note in this connection the various other entries during December, January and February, as for example, pp. 115, 151, 183, 186, 70, 80.

¿i Cf. e. g., Doc. of Revels, ed. Feuillerat, pp. 286, 320-21. 
however, should be eited here. It reads: "For the Cariadge of the partes of ye well counterfeit from the Bell in gracious strete to St. Johns to be performed for the play of Cutwell." ${ }_{68}$

This entry looks as though the properties of regular companies were being used at court. Fleay ${ }^{69}$ identifies Cutwell with the Irish Knight, one of the plays presented at Court between February 12, 1577, and the 21 of the following February. Feuillerat, ${ }^{70}$ however, thinks that it was not one of the nine plays acted between those dates, and that the carriage of the well to St. Johns points to the rehearsal of a play that was not accepted for court presentation. Be this as it may, the entry shows that the property of a regular company was at least used in court rehearsals, and that its carriage was being paid for by the Revels Office. The cloud ${ }^{71}$ which was probably borrowed from a public theatre and which was set up again where it was borrowed has already been mentioned.

In connection with the evidence above, we should take into consideration the economy of Lord Burghley and the growing parsimony of Elizabeth. From the year 1573, when Burgley undertook to reform matters, the yearly expenditure for court entertainments steadily decreases, $1580-81$ being exceptional as a result of the special amusements provided for the Duke of Alençon. On October 31, 1596, the Master of the Revels was allowed $£ 66$ 6s. 8d. for "defraying the ordinary charges and services within that office." "i2 That this amount was not increased in the following years is shown by the statements printed on pages 398-404 of Feuillerat's Documents of the Revels. The number of plays, however, did not decrease; ${ }^{73}$ nor is there any special reason for believing that they were less elaborately presented than the plays of the years immediately preceding. The regular companies, who had waxed so rich that they could now build stately houses, provided more of their own "furnitnre." 74

These "sundry thinges" furnished by the regular companies

s8 Ibid., 277.

${ }^{69}$ Biog. Chron., II, 289.

${ }^{70}$ Doc. of Revels, p. 461.

${ }^{71}$ Ibid., p. 308.

${ }^{2}$ Doc. of Revels, p. 397.

${ }^{73}$ Fleay, Hist. of Stage, pp. 121 ff.; Chambers, Mod. Lang. Review, II, pp. 7 ff.

${ }^{74}$ Feuillerat, Bureau des Menus-Plaisirs, p. 44. 
could not have differed materially from those provided by the Revels Office; and in both instances there are good reasons for believing that these Elizabethans were more painstaking in their attempts at coleur locale than they are sometimes given credit for being. Glaring anachronisms in dress as in other particulars are of course to be found, but there is considerable evidence to show that in many cases the theatrical people of the time were extremely careful in providing appropriate costume, distinctive and suggestive dress. To what extent the more advanced methods employed at court affected the public theatre, ${ }^{75}$ it is impossible to say; still it is perhaps worthy of remark that the very characters who were favorites at court-Mercury, Cupid, Iris, for example-seem to have been dressed in an exceptionally fitting manner at the public theatres. At least I am unable to agree with Reyher who concludes an excellent chapter on court costume with the words :

"Les comédiens des théâtres publics n'attachaient d'importance qu'à la richesse de leurs vêtements, sans se préoccuper de savior s'ils étaient appropriés aux rôles qu'ils devaient joner. Ils recevaient des grands leurs habillements d'apparat; laquais et soubrettes leur vendaient les défroques démodeés ou fripeés de leurs maîtres, et les acteurs, se pavanant sur la scène dans ces beaux atours, se contentaient de jeter de la poudre aux yeux de leurs humbles admirateurs."

For reasons already given, this comment seems hardly just. That actors sometimes secured costumes in the manner stated above is true enough, but a glance at Henslowe's Diary is sufficient to show that it was not the usual practice.

I am not one of those who "Taboriously attempt" to show that Shakspere dressed his Romans in the costume of Caesar's day. Nor do I intend to discuss here the matter of Elizabethan stage costume. I will say, however, that in certain performances at least the actors were not only careful about the costumes of their nymphs, shep-

75 The absence of Revels Accounts corresponding to the years covered in Henslowe's Diary renders it impossible to say whether the tailors, costumers, etc., working at court were the same as those working for public actors. And if it could be established that they were the same, this would prove nothing one way or the other. It is of some interest to know, however, that John Ogle, who frequently provided beards for court performances, also had as customers the professional actors of the day (Sir Thomas More, Pub. Sh. Soc., III, p. 59). Wm. Stone, mercer, also occupied a similar position (Doc. of Revels, pp. 346, 353, 368; Henslowe's Diary, I, 146; II, 313). 
herds, gods and goddesses, their Fame's and Nobody's, but were inclined to distinguish the habits of their Moors and Turks, their Irish, Italians and Scots. Symbolic colors, suggestive properties, fantastic devices were resorted to in an endeavor at clearness and differentiation. Grotesque and conventional dresses are frequently the result; yet even this, it seems to me, is of some value in showing that considerable care was being manifested with respect to personal appearance.

And in some of their methods they are strikingly modern. Masks, it is often said, were frequently used; yet the art of makeup was not entirely unknown. "Glue" for beards, for example, "sunne-burnt hands," a make-up capable of being defaced by the sun and perspiration are not unheard of in Shakspere's day. A picture frame stage with its attendant illusion, and Belasco-like preciseness in details of presentation were of course undreamed of in Elizabeth's reign. Ornament and pageantry, however, theatrical devices as aids to the imagination, the power of suggestion, the possibilities that lie in sounds on and off the stage as aids to illusion, and the hidden causes of strange effects that rise from "hell" or fall from "heaven" are by no means modern discoveries.

In the practice of such things it is obvious, too, that all the ingenuity of sixteenth century England was not being confined to the performances before the Queen. Some of the methods employed at court could not be easily and profitably introduced upon the public stages; others could be advantageously employed there. And with respect to such there is every reason to believe that the professional actors of the time profited by what they saw when they rehearsed before the Master of the Revels and performed before Her Majesty; that during the years when their very existence depended upon their connection with, and their ability to provide amusement for, Elizabeth and her circle, these same actors and stage-managers received at court things other than protection. Chief among these were, as I have tried to show, suggestions for the essential elements of a stage flexible, "painted," well-equipped. 


\section{APPENDIX}

\section{The "Canopy Stage."}

The word "canopy" (see above) has been used to distinguish from "alcove" the type of rear stage recently discussed by Creizenach and others; that is, a recess beneath an upper stage slightly projected and supported at the front by two pillars resting upon the lower stage (See above and Creizenach, Geschichte, IV, 430). Neuendorff in his Die englische Volksbühne regards this as the type of stage which he calls the fully developed form in the public theatres. Corresponding to it in the private theatres was the "alcove" stage-a distinction for which I see no grounds. A good deal, however, can be said for the "canopy" stage.

Note in this connection: (1) The Roxana picture does not speak against it, whereas the Messallina picture certainly seems to suggest it (cf. Neuendorff, pp. 28, 29, 140-143, 145-146; J. Q. Adams, Jr., Journal of Eng. and Germ. Philology, April, 1911, p. 322); (2) Two extra avenues of exit and entrance are provided with the curtains closed; (3) The "canopy" of Marston and Percy admirably describes such a structure; (4) If we assume a stage with both projecting balcony and oblique doors, then the closerange courting in The Devil Is an Ass, II, 2, can be staged excellently, although such an arrangement is unnecessary for the scene (cf. Reynolds, Mod. Phil., IX, 63) ; (5) Some extra space is given to the rear stage; (6) The Hope contract, which expressly states that the "heavens" are not to be supported by pillars, also states that turned columns are to be upon the stage; (7) Posts, in addition to the front pillars, are implied in the words of the Fortune contract, "Saveinge only that all the princypall and maine postes of the saide frame, and stadge forward shall be square," etc. And the posts occasionally called for in the action of plays were in some cases at least the posts supporting the upper stage rather than the pillars supporting the "shadow." Two Angry Women, sc. xi, Spanish Tragedy, III, 1, Three Lords and Three Ladies, p. 500, are not clear. In Friar Bacon, sc. xi, however, it is pretty certain that the post against which Miles strikes his head is near the brazen head on the rear stage, and is not the pillar at the front of the stage. Nor were posts on the stage confined to 
public theatres, as is shown in IV, 3, of Day's Humour Out of Breath (pub. 1608, as "Direr's times latelie acted by the children of the Kings Revells"), where Horatio courts Florinel's glove pinned to a post. The probability that the rear stage grew out of structures to represent interiors on the court stage may perhaps be suggested as a final bit of evidence in favor of Creizenach's idea.

The possible objection that a curtain suspended a few feet beyond the line of the tiring-house rould be difficult to manage is of little weight. We need not worry about the inability of these Elizabethans to manage curtains. They were used to managing them. The expression in the Rerels Account for 1578-9 (Feuillerat, p. 296) is suggestive: "ffor ii Lymes to drawe curtens withxii d." Even more suggestive is the derice used by Churehyard when Queen Elizabeth, in 1578, made her progress into Norfolk and Suffolk. A large hole was dug in which music and nymphs were stationed. Covering the hole was a "canvas painted greene like the grasse; and at everie side on the canvas ran a string through curteine rings, which string might easilie be drawne anie kind of waie, by reason of two great poales that laie along in the ground, and answered the curteine or canvas on each side so that drawing a small cord in the middle of the canvas, the earth would seem to open, and so shut againe as the other end of the cord was drawne backward" (Holinshed, IV, 400). There is no especial reason for thinking that Churchyard was more ingenious than Jas. Burbage or $\mathrm{Wm}$. Shakspere.

A few persons in the side boxes and groundlings at the sides of the stage could perhaps get glimpses of things behind the curtain, but such glimpses are not unknown today. Is it the inquisitiveness of the few spectators standing at the sides of the stage that is referred to in Lady Alimony (before 1642): "Be your stage curtains artificially drawn and so covertly shrouded that the squint-eyed groundling may not peek in?" And is it to Tarleton's habit of peeping around the slightly projecting curtain that Peacham refers in Thalia's Banquet (1620):

"As Tarlton when his head was onely seene,

The Tire-house doore and Trapistrie betweene.

Set all the multitude in such a laughter,

They could not hold for scarce an houre after?" 


\section{INDEX OF AUTHORS AND TITLES}

Acolastus, 16.

Adams, J. Q., Jr., 88.

Aglaura, 6.

Albion Knight, $60 \mathrm{n}$.

Abraham Sacrifant, $52 \mathrm{n}$.

Albright, V. E., 17, 22, 57 n., 60 n., $64,67$.

Alexander and Campasbe, 62.

All Fools, $26 \mathrm{n}$.

All for Money, $60 \mathrm{n}$.

Alphonsus of Arragon, 12, 63, 67, 71. Antipodes, 25.

Antonio's Revenge, 13 n., 19.

Apius and Virginia, $50 \mathrm{n}$.

Apology for Actors, 16, 25, 69 .

Archer, Wm., 28.

Arden of Feversham, 17 n., 65, 66.

Arraignment of Paris, 62 .

Astrologaster, 25.

Astrophel and Stella, 23.

As You Like It, 63.

Babington, Bishop, $40 \mathrm{n}$.

Baker, G. P., 9 n., 46, 48, 78, 79.

Bale, John, $60 \mathrm{n}$.

Bang, W., 8.

Bartholomew Fair, 17 n.

Battle of Alcazar, 19, 81.

Belman of London, 68.

Bereblock, John, 44.

Beza, 52 n.

Blurt, Master Constable, 13 n.

Bohun, Edmund, $77 \mathrm{n}$.

Brandl, A., 57 n., 60 n.

Brathwaite, Rich., 70.

Brazen Age, 13 n., 25.

Brome, 16, 25.

Brooke, Tucker, $43 \mathrm{n}$.

Browne, 21.

Bugbears, $51 \mathrm{n}$.

Bussy D'Ambois, 19.

Calisto and Melibea, $50 \mathrm{n}$.

Cambises, 53, 56.

Careless Shepherdess, 20.

Carleton, Sir Dudley, 74.
Castle of Perseverance, 64.

Chamberlain, John, 19, 22.

Chambers, E. K., 38.

Chapman, Geo., 26 n.

Character of Queen Elizabeth, $77 \mathrm{n}$.

Character Writings of Seventeenth Century, 25.

Child, H. H., 28, 29, 34, 46.

Churchyard, Thos., 89.

Cohen, G., 47 n., 52 n.

Common Conditions, 62.

Comodie of Bewtie and Huswyfery, $50 \mathrm{n}$.

Comodie or Moral devised on $A$ Game of Cardes, $51 \mathrm{n}$.

Conflict of Conscience, $57 \mathrm{n}$.

Corbin, John, 9 n., 22.

Corey, 80.

Coryat's Crudeties, 68.

Cotgrave, J., 23.

Creizenach, W., 49, 56, 67 n., 88 .

Cross, 69.

Cunliffe, J. W., 57.

Cutwell, 85.

Cynthia's Revels, 19, 79.

Cypress Grove Walks, 20.

Damon and Pithias, 52, 52 n., 60.

Daniel, S., 79 n.

David and Bethsabe, 9 n., 21.

Day, John, 20, 89.

Death of Robert Earl of Huntington, 82.

Dekker, 15, 26 n., 62 n., 68, 70, 72, $76,82 \mathrm{n}$.

Devil Is An Ass, 88.

Development of Shakespeare as a Dramatist, $9 \mathrm{n}$.

Disobedient Child, 53, $60 \mathrm{n}$.

Drake, 79.

Drayton, M., 68.

Drummond of Hawthorndon, 20.

Durand, 44 n., 45, 46.

Dux Moraud, $60 \mathrm{n}$.

Early London Theatres, 29. 
Eastuvard Hoe, 11, 13 n.

Edward IV, 18, 20.

Edwards, Rich., 44, 52.

Endymion, 19, 62 .

Englische Volksbïhne im Zeitalter Shakespeares, 4.

Englysshe Mancyne, 16.

England's Joy, 70, 77.

Ev. B., 68.

Every Man in his Humor, 12.

Faery Pastorall, 12.

Fair Maid of the Exchange, $75 \mathrm{n}$.

Feuillerat, A., 1 n., 2, 9 n., 54 n., 24 n., 84, 85 .

Fleay, F. G., 34, 35 n., 67 n., 85.

Flecknoe, $35,36,80$.

Florio, John, 15, 16, 17.

Ford, John, 21.

Four Elements, $60 \mathrm{n}$.

Four Prentices of London, $13 \mathrm{n}$.

Four P's, $60 \mathrm{n}$.

Fraunce, A., 51 n., 66 .

Friar Bacon and Friar Bungay, 64, s8.

Gallathea. 62.

Gammer Gurton's Needle, 50, 54, 60.

Gascoigne, Geo., 50, 56 .

George-a-Greene, 67 .

Gesta Grayorum, 44.

Gismond of Salerne, 58, 60, 66.

Glass of Government, 51 n., 52, 56 .

Godly Queen Hester. 8, 57.

God's Promises, $60 \mathrm{n}$.

Golding, $52 \mathrm{n}$.

Gorboduc, 52, 57 .

Gosson, Stephen, 23, 69, 81.

Greg, W. W., 8, 17 n., 79 n.

Greene, Robt., 12, 63, 67, 71, 82 .

Grindal, 40 n.

Halliwell, J. O., 34 .

Harrison, Robt., 36.

Harvey, Gabriel, 69, 79.

Helmholz-Phelan, Mrs., 80 n., 83.

Henslowe's Diary, 69, 84, 86, 86 n.

Henry VI, 25.

Henry VIII, 11.

Hentzuer, 42.
Heywood, John, $60 \mathrm{n}$.

Heywood, 'Thos., 16, 20, 25, 69, 74, $75 \mathrm{n}$.

History of Knight in Burniny Rock, $56 \mathrm{n}$.

History of Love and ffortune, $56 \mathrm{n}$.

Histriomastix, $17 \mathrm{n}$.

Holiday, $25 \mathrm{n}$.

Holinshed, R., 24 n., 45, 89.

Holyoke, Thos., 14.

Horestes, 55, 61.

Howe, 34, 36, 43.

Hughes, Thos., 57 .

Humour out of Breath, 20, 89.

Hyckescorner, $60 \mathrm{n}$.

Hymenaei, 27, 72 .

Hymenaeus, $51 \mathrm{n}$.

If This Be not a Good Play. 13 n., 16.

If You Know Not Me, 67.

Impatient Poverty, $60 \mathrm{n}$.

Ingeland, John, 53 .

Irish Knight, 85.

Jack Juggler, 50.

James IV, 81, 82.

Jocasta, 51 n., 52 .

Johan Johan, 57, 57 n., 66.

Iohn a Kent anel John a Cumber, 71, 76.

Jusserand, J. J., 59 n.

John the Baptist, $60 \mathrm{n}$.

Jonson, Ben, 1, 10, 26, 68, 69, 72, 73.

Joviall Crew, 16.

King Darius, 60.

King Johan, $60 \mathrm{n}$.

Knack to Know an Honest Man, 65, 81.

Lady Alimony, 89.

Lawrence, W. J., 9 n., 48, 49, 51 n., $53 \mathrm{n}$.

Legge, Thos., 9 .

Lemazurier, $67 \mathrm{n}$.

Liberality and Prodigality, 62.

Like Will to Like, $60 \mathrm{n}$.

Locrine, 81.

Looking Glass for London, 19, 75, 76.

Longer Thou Livest, $50 \mathrm{n}$.

Lord Cromuell, 18, 64 n., 66. 
Lost Lady, 18 n.

Love, $60 \mathrm{n}$.

Love Feigned and Unfeigned, $60 \mathrm{n}$.

Love's Labour Lost, 82.

Loves Metamorphosis, 62, 79.

Love's Sacrifice, 21.

Lupton, Donald, 71.

Lusty Juventus, $60 \mathrm{n}$.

Lyly, John, 58, 62.

Maas, 36 n., 83.

Magnificence, $60 \mathrm{n}$.

Malone, Edmund, 1, 32, 48.

Mankind, 44 n., 57 n.

Marlowe, 9 n., 81 .

Marriage of Wit and Scienee, 54, 55, $60 \mathrm{n}$.

Marriage of Wit and Wisdom, 63.

Mary Magdalene, 57 и.

Marston, John, 12, 16, 88.

Masque of Blackness, 74, 80.

Masque of Flowers, 80.

Maydes Metamorpliosis, 62, 63.

Midas, 62.

Midsummer Night's Dream, 62, 63.

Milton, John, 25.

Mind, Will and Understanding, $60 \mathrm{n}$.

Misfortunes of Arthur, 52, 5\%.

Misogonus, 58, 60, 66.

Monday, A., 66.

Mouster Lately Found Out, 34.

Morgan, Appleton, 39, 48.

Morley, John, 25.

Moryson, Fynes, 70 .

Mother Bombie, $64 \mathrm{n}$.

Mucedorns, 61, 63.

Mutius Sceuola, $50 \mathrm{n}$.

Narcissus, 71, 75.

Nash, Thos., 9 n., 23, 2.5, 69.

Neuendorff, B., 1 n., 3, 4, 6, 7, 11, 12, $17,19,21,22,29$ n., 30, 31, 67 n., 74, 75 n., 78, 8 s.

Nev Custom, 50 1., $60 \mathrm{n}$.

Nevos from IIell, 26 и.

Nice Wauton, $57 \mathrm{n}$.

Nobody and Somebody, $64 \mathrm{n}$.

Novella, 21.

Old Wives Tale, 58, $64 \mathrm{n}$.
Ordish, T. F., 29, 39 .

Orlando Furioso, 61, 63.

Palamon and Arcyte, 44.

Palsgrave, John, 16, 27.

Pardoner and Friar, $60 \mathrm{n}$.

Pastorall of Phillyda and Choryn, $9 \mathrm{n}$.

Patient Grissell, 62.

Peacham, 89.

Peake, Robt., 51 n.

Pedler's Prophecy, 60.

Peele, Geo., 62.

Pericles, 19.

Percy, Wm., 12, 14, 16, 17, 62 n., 88. Peters, Nicholas, 24.

Phillips, John, 62.

Pinciano, $51 \mathrm{n}$.

Plautus, 50.

Plaie of the Burnyng Knight, 27.

Playe of fayeton, 84.

Play of Plays, 23.

Play of Thomas Stucley, 25, 73.

Play of Wyt and Science, 55, 61.

Plays Confuted, 69, 81.

Portio and Demorantes, 53.

Prynne, Wm., 34.

Queen Dido, 9 n., 62, 84.

R. M., 25.

Raleigh, Sir Walter, 20.

Ralph Roister Doister, 50, 60.

Rave Trinmphs of Love and Fortune, 61.

Rawlidge, 34, 35 .

Redford, Jolın, 55, 61 .

Remains after Death, 70 .

Rendle, 41.

Rennert, H. A., $37 \mathrm{n}$.

Respublica, $60 \mathrm{n}$.

Reyher, P., 2, 9 n., 17 n., 45 ı., 86.

Reynolds, G. F., 1 n., 11, 13 n., 17 n., 1S, 19, 21, 26 11., 28, 64, 65, 67 n., 75 11., 88.

Ricardus Tertius, 9.

Rigal, E., 58 n.

Roaring Girl, 17 n.

Romeo and Juliet, 67, 82.

Rye, W. B., 42.

San Hevemenegildo, $59 \mathrm{n}$. 


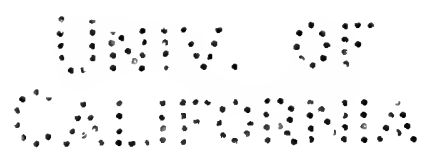

INDEX OF AUTHORS AND TITLES

Sapho and Phao, 58, 65.

Schelling, F. E., 1 n., 78.

Second and Third Blast of Retrait, 69 .

Sejamus, 68 .

Serlio, S., 51 11.

Shakspere, 1, 76, 89.

Shaksperian Stage, 22.

Shirley, John, $54 \mathrm{n}$.

Shoemaker a Gentleman, 18 n.

Sidney, Sir Philip, 1, 63, 73.

Sir Clyoman and Sir Clymades, 19, 63.

Sir John Oldcastle, 66.

Sir Thomas More, $57 \mathrm{n}$.

Sophinisba, 12.

Spanish Tragedy, 82, 88.

Spenser, E., 68, 79.

Spinelli, 45.

Steevens, George, 1, 10.

Stockwood, J., 35, 36, 68.

Story of Pompey, 58.

Stowe, J., 43.

Stuart, D. C., 52 n.

Suckling, Sir John, 6.

Sun's Darling, 9 n.

Supposes, 50 .

Tamer Cam, 81.

Tamburlaine, 74, 75.

Tancred and Gismunda, 9 n., 19.

'Tarleton, R., 35.

Tatham, J., 19.

Tears of the Muses, 68.

Technogamia, $25 \mathrm{n}$.

Temperance and Humility, $60 \mathrm{n}$.

Terence, 50.

Tethys Festivall, 79 n.
Thalia's Banquet, 89.

Thersites, 52.

Three Laws, $60 \mathrm{n}$.

Three Lords of London, 66, 81.

Three Lords and Three Ladies of London, 88.

Tide Tarrieth No Man, $60 \mathrm{n}$.

Tom Tyler, 60.

Trial of Treasure, $60 \mathrm{n}$.

Troublesome Reign of King John, 25.

Two Angry Women of Abington, 88.

Two Italian Gentlemen, 66.

Two Tragedies in One, $57 \mathrm{n}$.

Varian, George, 22.

Vennor, R., 70, 77.

Vertues Commonwealth, 69 .

Victoria, 51 n., 66.

Vitruvius, $51 \mathrm{n}$.

Wager, W., $50 \mathrm{n}$.

Wallace, C. W., 28, 41, 81.

Wapul, G., 60 n.

War's of Cyrus, 62, 81.

Wealth and Health, $60 \mathrm{~m}$.

Weever, John, 28, 68.

Wegener, R., 57.

Wether, $60 \mathrm{n}$.

What You Will, 12.

White, Thos., 68.

Whore of Babylon, $9 \mathrm{n}$.

Wit and Witless, $60 \mathrm{n}$.

Witte and Will, 55.

Woman in the Moon, 25 n., 62.

Woman Killed with Kindness, $75 \mathrm{n}$.

Youth, $50 \mathrm{n}$. 
$\because \vdots \vdots \quad \because \vdots \vdots \vdots \vdots \vdots \vdots \vdots \vdots 0$

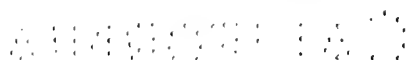

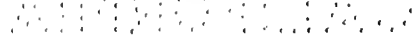




\section{RETURN CIRCULATION DEPARTMENT}

TO $\rightarrow 202$ Main Library

\begin{tabular}{l|l|l}
\hline $\begin{array}{l}\text { LOAN PERIOD 1 } \\
\text { HOME USE }\end{array}$ & 2 & 3 \\
\hline 4 & 5 & 6 \\
\hline
\end{tabular}

ALL BOOKS MAY BE RECALLED AFTER 7 DAYS

Renewals and Recharges may be made 4 days prior to the due date.

Books may be Renewed by calling $642-3405$.

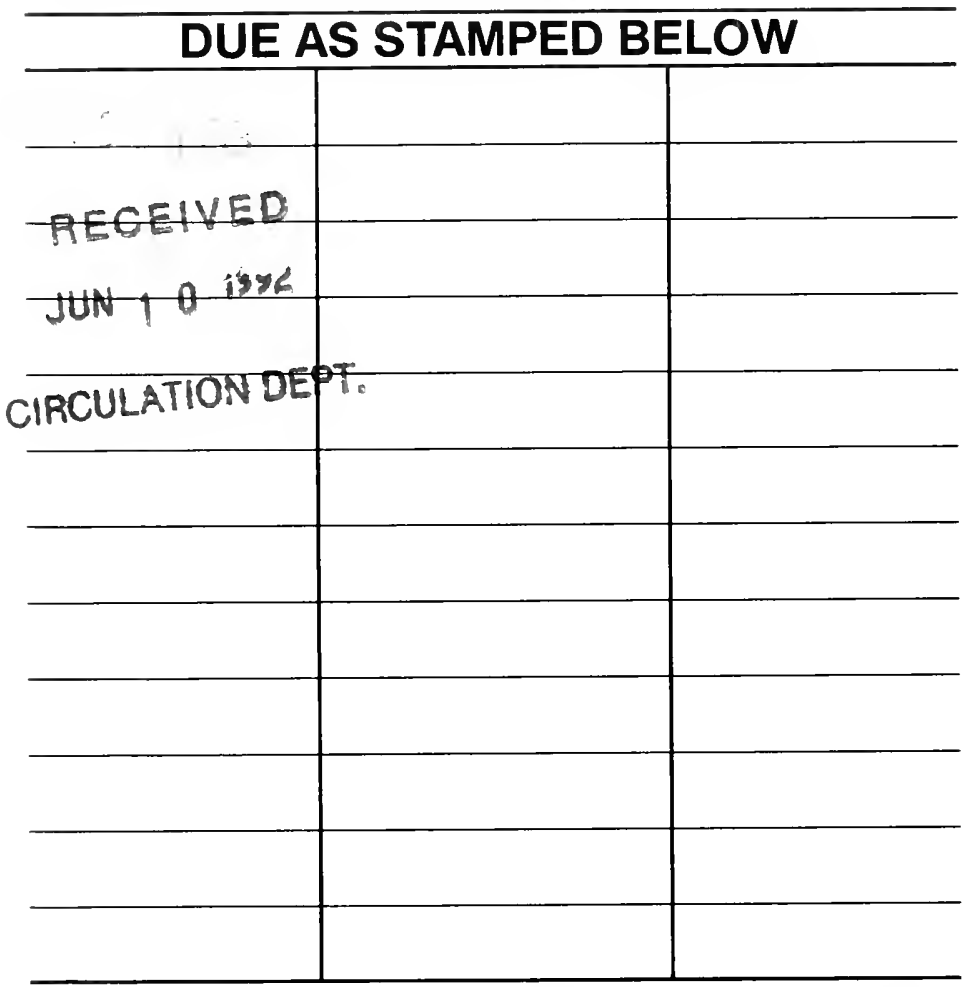

FORM NO. DD6

UNIVERSITY OF CALIFORNIA, BERKELEY BERKELEY, CA 94720 


\section{U.C. BERKELEY LIBRARIES

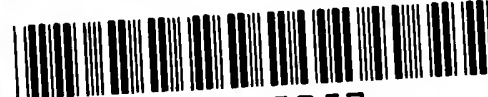 c007009357}


